\title{
STATISTIK ILMU SOSIAL
}

\author{
UDA GERARDUS \\ ASTRI ATTI \\ MARIA AGUSTINA KLEDEN
}

LEMLIT UNDANA 


\title{
STATISTIK ILMU SOSIAL
}

\author{
Uda Gerardus \\ Astri Atti \\ Maria Agustina Kleden
}

PENERBIT LEMLIT UNDANA

2019 


\section{STATISTIK ILMU SOSIAL}

\section{Uda Gerardus}

Astri Atti

\section{Maria A. Kleden}

Copyright (C) 2019 Uda Gerardus, Astri Atti, Maria A. Kleden

Editor

: Maria Lobo

Desain Sampul

: Ridwan Kamal

PT Penertbit

: LEMLIT UNDANA

Cetakan Pertama

: Desember 2019

ISBN

: 978-602-6478-76-4

Hak Cipta dilindungi oleh undang-undang

Dilarang memperbanyak buku ini tanpa izin tertulis dari Penerbit 


\section{DAFTAR ISI}

$\begin{array}{ll}\text { KATA PENGANTAR } & \text { iii }\end{array}$

DAFTAR ISI iv

BAB I Penyajian Data 1

BAB II Distribusi Frekuensi 11

BAB III Ukuran Gejala Pusat dan Ukuran Letak 20

BAB IV Ukuran Disperesi/Penyebaran 33

BAB V Konsep Peluang 39

BAB VI Distribusi Normal 53

BAB VII Analisis Komponen Utama (Principal Component Analysis) 60

$\begin{array}{lll}\text { BAB VIII Analisis Faktor (Factor Analysis) } & 77\end{array}$

BAB IX Analisis Diskriminan (Discriminant Analysis) 94 


\section{Kata Pengantar}

Puji dan syukur penulis panjatkan ke hadirat Allah Yang Maha Agung atas berkatNya yang dilimpahkan kepada para penulis sehingga buku Statistik IImu Sosial ini dapat terselesaikan.

Buku ini dimaksudkan untuk membantu mahasiswa mememahmi konsep konsep dasar Statistik dan statistic multivariate serta aplikasinya dalam beberapa kasus yang merupakan diseminasi dari hasil penelitian para penulis. Buku ini dapat digunakan para peneliti dalam memahami penggunaan statistik bagi penelitian-penelitian social. Dalam setiap bab dilengkapi dengan uraian materi, contoh soal, soal latihan dan daftar pustaka untuk membantu pembaca memperdalam materi dan kasus yang dibicarakan.

Terimakasih penulis sampaikan kepada semua pihak yang telah membantu penulis dengan caranya masing-masing sehingga buku ini dapat diterbitkan.

Semoga buku ini bermanfaat bagi pembaca.

Kupang, September 2019

Penulis 


\section{BAB I \\ PENYAJIAN DATA}

\subsection{PENGANTAR}

Hasil penelitian, riset maupun pengamatan biasanya dinyatakan dan dicatat dalam bentuk bilangan atau angka-angka. Kumpulan angka-angka itu sering disusun, diatur atau disajikan dalam bentuk daftar atau tabel. Sering pula daftar atau tabel tersebut disertai dengan gambar-gambar yang biasa disebut diagram atau grafik supaya lebih dapat menjelaskan lagi tentang persoalan yang sedang dipelajari. Penyajian data ini dimaksudkan untuk memudahkan peneliti menyajikan data yang diperoleh, sehingga mempermudah pembaca mengali informasi yang terkandung dalam data tersebut.

Dunia penelitian atau riset, mendapatkan manfaat yang baik dari statistika dan menggunakannya. Untuk mengetahui apakah cara yang baru ditemukan lebih baik dari pada cara yang lama, melalui riset yang dilakukan di laboratorium, atau penelitian yang dilakukan di lapangan, perlu diadakan penilaian dengan statistika. Sesungguhnya, statistika sangat diperlukan bukan saja hanya di dalam penelitian atau riset, tetapi juga perlu di dalam bidang pengetahuan lainnya seperti : teknik, industri, ekonomi, astronomi, biologi, kedokteran, asuransi, pertanian, pengetahuan alam, pengetahuan sosial, dan lain sebagainya.

Pada bagian awal dari bab ini, akan dibahas mengenai statistika dan statistik, peranan statistika, data statistik, populasi dan sampel, pengumpulan data, penyajian data dalam bentuk diagram.

Oleh karena itu, setelah mempelajari bab ini, Anda diharapkan dapat menjelaskan pengertian statistik dan statistika, peranan statistika dalam berbagai bidang kehidupan, menjelaskan definisi data dan macam-macam data, membedakan populasi dan sampel, menjelaskan berbagai metode yang dapat digunakan untuk mengumpulkan data, serta menjelaskan berbagai diagram yang dapat digunakan untuk menyajikan data.

\subsection{URAIAN MATERI}

\section{A. Statistik dan Statistika}

Statistik adalah kumpulan angka-angka mengenai suatu masalah sehingga dapat memberikan gambaran mengenai masalah tersebut. Atau dengan kata lain statistik menyatakan kumpulan data, bilangan maupun non bilangan yang disusun dalam tabel atau diagram yang melukiskan atau menggambarkan suatu persoalan. Statistik yang menjelaskan sesuatu hal biasanya diberi nama statistik mengenai hal yang bersangkutan. Demikianlah umpamanya kita mengenal : statistik penduduk, statistik kelahiran, statistik pendidikan, statistik produksi, statistik pertanian, statistik kesehatan dan masih banyak lagi.

Kata statistik juga masih mengandung pengertian lain, yakni dipakai untuk menyatakan ukuran sebagai wakil dari kumpulan data mengenai sesuatu hal. Ukuran ini didapat berdasarkan perhitungan menggunakan kumpulan sebagian data yang diambil dari keseluruhan tentang persoalan tersebut. Umpamanya kita telah mengenal kata-kata persen dan rata-rata. Jika kita teliti 20 pegawai dan 
dicatat gajinya setiap bulan lalu dihitung rata-rata gajinya, misalnya Rp. 87.500,00 maka rata-rata Rp. 87.500,00 ini dinamakan statistik. Demikian pula, jika dari ke 20 pegawai itu ada $40 \%$ yang gajinya tiap bulan kurang dari Rp. $60.000,00$ maka nilai $40 \%$ ini dinamakan statistik.

Statistika adalah metode ilmiah yang mempelajari pengumpulan, pengaturan, perhitungan, penggambaran dan penganalisaan data, serta penarikan kesimpulan yang valid berdasarkan penganalisaan yang dilakukan dan pembuatan keputusan yang rasional.

Secara garis besar ilmu statistika dapat dibagi menjadi dua macam yaitu :

a. Statistika deskriptif atau statistika deduktif adalah statistika yang meliputi kegiatan-kegiatan pengumpulan, penyajian, penyederhanaan, atau penganalisan, dan penentuan ukuran-ukuran khusus dari suatu data tanpa penarikan kesimpulan seperti diagram lingkaran, tabel dan lain-lain.

b. Statistika inferensi atau statistika induktif adalah ilmu mengenai penarikan kesimpulan dan pengambilan keputusan tentang makna statistik yang telah dihitung, diantaranya : macam data, skala data, notasi jumlah, ukuran pusat data dan sifat data.

\section{B. Peranan Statistika}

Dalam kehidupan sehari-hari sering kita mendengar ataupun membaca pernyataan-pernyataan seperti : tiap bulan habis Rp. 50.000,00 untuk keperluan rumah tangga, ada $60 \%$ penduduk yang memerlukan perumahan, setiap hari terjadi 13 kecelakaan kendaraan di Provinsi Nusa Tenggara Timur, hasil padi musim panen mendatang diperkirakan 50 kwintal tiap hektar dan $10 \%$ anak-anak SD mengalami putus sekolah tiap tahun. Ini adalah beberapa contoh praktis penggunaan statistika. Pemerintah menggunakan statistika untuk menilai hasil pembangunan masa lalu dan juga untuk membuat rencana masa datang. Pimpinan mengambil manfaat dari keguanan statistika untuk melakukan tindakan-tindakan yang perlu dalam menjalankan tugasnya, misalnya apakah perlu mengangkat pegawai baru, sudah waktunya untuk membeli mesin baru, bagaimana kemajuan usaha tahun-tahun yang lalu, berapa banyak barang yang harus dihasilkan setiap tahunnya dan masih banyak lagi.

Dunia penelitian atau riset, dimanapun dilakukan, bukan saja telah mendapatkan manfaat yang baik dari statistika tetapi sering harus menggunakannya. Untuk mengetahui apakah cara yang baru ditemukan lebih baik dari pada cara yang lama, melalui riset yang dilakukan di laboratorium, atau penelitian yang di lakukan dilapangan, perlu diadakan penilaian dengan statistika. Apakah model untuk sesuatu hal dapat kita anut atau tidak, perlu diteliti dengan menggunakan teori statistika. Statistika juga telah cukup mampu untuk menentukan apakah faktor yang satu dipengaruhi atau mempengaruhi faktor yang lainnya. Sesungguhnya, statistika sangat diperlukan bukan saja hanya di dalam penelitian atau riset, tetapi juga perlu di dalam bidang pengetahuan lainnya seperti : teknik, industri, ekonomi, astronomi, biologi, kedokteran, asuransi, pertanian, pengetahuan alam, pengetahuan sosial, dan lain sebagainya. 


\section{Data Statistik}

Keterangan atau ilustrasi mengenai sesuatu hal bisa berbentuk kategori, misalnya : rusak, baik, senang, puas, berhasil, gagal dan sebagainya atau bisa berbentuk bilangan. Kesemuanya ini dinamakan data atau selengkapnya data statistik.

Dalam statistika, menurut sifatnya data dibagi menjadi dua yaitu :

a. Data kuantitatif yaitu data yang berbentuk bilangan dan harganya berubahubah atau bersifat variabel. Contohnya: IP mahasiswa, Luas tanah Undana adalah $5.700 \mathrm{~m}^{2}$, Tinggi badan Patrick adalah $175 \mathrm{~cm}$, Banyaknya Perguruan Tinggi di Provinsi NTT adalah ada 10 unit

b. Data kualitatif yaitu data yang tidak berbentuk bilangan atau data yang dikategorikan menurut lukisan kualitas obyek yang dipelajari. Golongan ini dikenal pula dengan nama atribut misalnya : sembuh, rusak, gagal, berhasil. Golongan darah mahasiswa baru Undana, A, B, AB, dan O.

Data kuantitatif dibedakan atas dua, yaitu :

a. Data diskrit (data dengan variabel diskrit) adalah data yang diperoleh dengan cara menghitung. Misalnya: keluarga Pak Robert mempunyai 3 anak laki-laki dan 2 anak perempuan, jumlah peserta remedial matrikulasi mata ajar statistik dasar sebanyak 20 orang, dll.

b. Data kontinu (data dengan variabel kontinu) adalah data yang diperoleh dengan cara mengukur. Misalnya : luas daerah perkebunan kopi Pak Hendrik sebesar 425,7 $\mathrm{m}^{2}$, Jarak antara kota Kupang dan kota Atambua adalah 245,70 $\mathrm{km}$.

Sedangkan menurut cara memperolehnya, data diklasifikasikan sebagai berikut :

a. Data primer adalah data yang dikumpulkan dan diolah sendiri serta diperoleh langsung dari obyeknya.

b. Data sekunder adalah data yang diperoleh dalam bentuk sudah jadi, sudah dikumpulkan dan diolah oleh pihak lain.

Dalam mengumpulkan data, kita sering menemukan suatu kondisi bahwa pengskalaan untuk sebuah kumpulan data. Beberapa skala pengukuran yang digunakan adalah :

a. Skala data nominal adalah data yang diperoleh dengan cara memberikan katagorisasi atau klasifikasi misalnya : petani : 1 , guru : 2 , nelayan : 3 , dokter : 4. Ciri-ciri skala data nominal yaitu posisi data setara dan tidak bisa melakukan data matematis atau operasi matematis.

b. Skala data ordinal adalah data yang diperoleh dengan katagorisasi dan mempunyai hubungan yang meningkat. Misalnya : data tentang tingkat kepuasan pelanggan. Ciri-ciri skala data ordinal yaitu : posisi data tidak setara dan tidak bisa dilakukan operasi matematis.

c. Skala data interval adalah data yang diperoleh dengan cara pengukuran dimana jarak diantara dua titik sudah diketahui. Misalnya data suhu disuatu tempat. Ciri-ciri skala data interval yaitu : tidak ada kategorisasi pada data yang dimiliki dan dalam melakukan data ini bisa dilakukan operasi matematis.

d. Skala data rasio adalah data yang diperoleh dengan cara pengukuran dimana jarak dua titik pada skala sudah diketahui dan mempunyai titk nol yng mutlak atau absolut. Misalnya : jumlah siswa disini adalah nol. Artinya disini tidak 
ada siswa. Ciri-ciri skala data rasio adalah : tidak ada kategorisasi dan bisa digunakan operasi matematis.

\section{Populasi dan Sampel}

Populasi adalah himpunan keseluruhan obyek yang diselidiki. Himpunan bagian dari populasi dinamakan sample. Karaksteristik atau konstanta dari suatu populasi disebut parameter. Sedangkan suatu harga yang dihitung dari suatu sample dinamakan statistik.

Analisa statistik dilakukan untuk dapat mengambil kesimpulan tentang parameter populasi berdasarkan observasi sample. Oleh karena itu sampel yang diperoleh hendaknya dapat memberikan gambaran yang "tepat" untuk populasinya (representatif). Dalam berbagai penelitian kerapkali dijumpai populasi yang berbeda-beda keadaannya, maka harus digunakan sample yang berbeda-beda pula macamnya. Khusus untuk populasi yang tidak terlalu heterogen, salah satu macam sample yang dianggap "representatif" adalah sample random dan observasi-observasi dalam sample independen satu dengan yang lain. Sampel random adalah sample yang pengambilannya sedemikian hingga setiap elemen populasinya mempunyai kemungkinan yang sama untuk terambil.

Kesimpulan yang dibuat mengenai suatu hal umumnya diharapkan berlaku untuk hal itu secara keseluruhan dan bukan hanya untuk sebagian saja. Jika dikatakan : 20\% mahasiswa di Indonesia berasal dari keluarga berpenghasilan rendah, maka pernyataan ini berlaku umum untuk mahasiswa di Indonesia ditinjau dari segi ekonomi. Untuk sampai pada pernyataan demikian, diperlukan data mentah yang bisa dikumpulkan dengan dua jalan:

a) Semua orang tua Indonesia beserta karakteristiknya yang diperlukan (keadaan ekonomi keluarga) diteliti atau dijadikan obyek penelitian.

b) Sebagian kecil dari semua orang tua mahasiswa yang dikenai penelitian.

Dalam hal pertama, sensus dilakukan untuk memperoleh data yang diinginkan, sedangkan dalam hal kedua penelitian dilakukan secara sampling.

\section{E. Pengumpulan Data}

Untuk statistika induktif diperlukan statistika deskriptif yang benar dan untuk hal terakhir diperlukan data. Data harus menyatakan kebenarannya agar dapat dipercaya. Proses pengumpulan data dapat dilakukan dengan jalan sensus atau sampling. Untuk kedua hal tersebut, sensus maupun sampling, banyak langkah yang dapat ditempuh dalam usaha mengumpulkan data, antara lain:

a. Mengadakan penelitian langsung ke lapangan atau di laboratorium terhadap obyek penilitian hasilnya dicatat untuk kemudian dianalisis.

b. Mengambil atau menggunakan, sebagian atau seluruhnya dari sekumpulan data yang telah dicatat atau dilaporkan oleh badan atau orang lain.

c. Mengadakan angket, yakni cara pengumpulan data dengan menggunakan daftar isian atau daftar pertanyaan yang telah disiapkan dan disusun sedemikian rupa sehingga calon respondennya hanya tinggal mengisi atau menandainya dengan mudah, tepat dan cepat.

Beberapa cara pengambilan sampel yang sering digunakan para peneliti adalah sampel random, sampel sistimatis dan sampel kelompok (cluster sampling). 
1. Sampel Random Sederhana

Sampel random sederhana adalah sampel yang pengambilannya sedemikian hingga setiap elemen populasinya mempunyai kesempatan/kemungkinan yang sama terambil. Proses pengambilan sampel tersebut sebaiknya dilakukan dengan bantuan tabel bilangan random (random digit table).

2. Sampel Sistimatis

Sampel sistimatis adalah sampel yang pemilihannya dilakukan secara sistimatis dari populasinya. Proses pengawasan kualitas pemilihan sampel dilakukan dengan cara pemilihan dan menguji semua produk yang dihasilkan tiap-tiap satu jam interval. Contoh : Proses pemilihan sampel mahasiswa yang akan diukur berat badannya. Pemilihan sampel dilakukan dengan cara memilih mahasiswa yang nomor mahasiswanya berakhiran 5 .

3. Sampel Kelompok (cluster sampling)

Sampel kelompok adalah sampel random sederhana dengan sampling unitnya berupa kumpulan atau kelompok elemen.

Contoh : Prosedur pemilihan sampel dalam penelitian untuk membuat perkiraan rata-rata pendapatan per rumah tangga di kota Kupang. Dalam hal ini kelompoknya terdiri dari beberapa rumah tangga dan disebut blok (RT), kemudian dilakukan pendaftaran rumah tangga pada setiap blok (RT) yang terpilih. Kelompok ini merupakan sampel dari penelitian.

\section{F. Penyajian Data Dalam Bentuk Diagram}

Untuk lebih mempermudah dalam memahami dan menganalisa data, maka penyajian data dapat dilakukan dengan menyajikan data tersebut dalam bentuk grafik.

Bentuk Diagram untuk data tidak berkelompok

\section{a. Diagram batang dan daun (steam and leaf)}

Diagram ini akan tepat dipakai untuk menyajikan hasil-hasil pengamatan yang tidak banyak dan nilai-nilainya semuanya lebih dari nol. Diagram batang daun segera memberikan gambaran dari bentuk suatu distribusi peubah yang masih tetap dinyatakan dalam nilai-nilai secara numerik dari data aslinya.

\section{Contoh 1}

San Chay setiap tahun berganti rumah kontrakan selama 15 tahun. Setiap berganti rumah selalu mencatat nomor rumahnya : 22, 54, 34, 59, 41, 35, 46, 41, 49, 46, 25, 46, 54, 68, 47. Maka diagram batang dan daunnya :

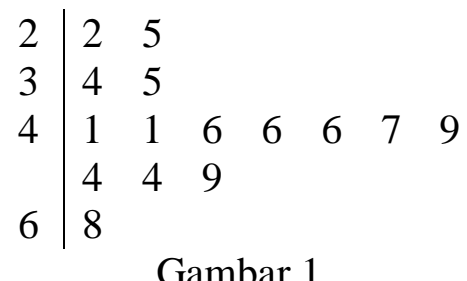

Berdasarkan diagram batang dan daun dapat dilihat beberapa hal penting :

* Tempat pemusatan data atau median.

Dilihat dari salah satu ujung diagram batang dan daun sampai separuh hasil pengamatan. Dalam contoh ini median adalah 46. 
Bentuk keseluruhan data simetrik, miring kiri atau miring kanan. Bentuk keseluruhan ini dapat dilihat sedemikian sehingga hasil pengamatan terbesar jatuh di sebelah kanan dan batangnya berada di bawah garis mendatar sebagaimana diberikan pada gambar 2 berikut:

\begin{tabular}{lllll} 
& & 9 & & \\
& & 7 & & \\
& & 6 & & \\
& & 6 & & \\
& & 6 & 9 & \\
& & 6 & \\
5 & 5 & 1 & 4 & \\
2 & 4 & 1 & 4 & 8 \\
\hline 2 & 3 & 4 & 5 & 6
\end{tabular}

Gambar 2

* Distribusi dari nomor kontrak rumah kontrakan San Chay mendekati simetris.

* Dari diagram batang dan daun dapat juga dilihat data pencilan yaitu data yang terletak diluar pola distribusi data itu. Data pencilan ini bisa terjadi karena kesalahan pencatatan, kesalahan alat dan lain-lain.

\section{b. Diagram Batang}

Diagram batang dibuat berdasarkan data berbentuk kategori atau atribut. Lebar tiap batang harus dibuat sama sedangkan frekuensi atau kuantitas atribut digambarkan oleh panjang atau tinggi batang.

\section{Contoh 2}

Jumlah siswa TK, SD, SMP, SMA, dan SMK di kota Kupang pada tahun 2010 masing-masing adalah : 110 orang, 1500 orang, 900 orang 1250 orang dan 870 orang.

Pada sumbu datar ditulis TK, SD, SMP, SMA, dan SMK sedangkan pada sumbu tegak ditulis jumlah siswa yang nilainya diambil dari 0, 400, 800, 1200,1600

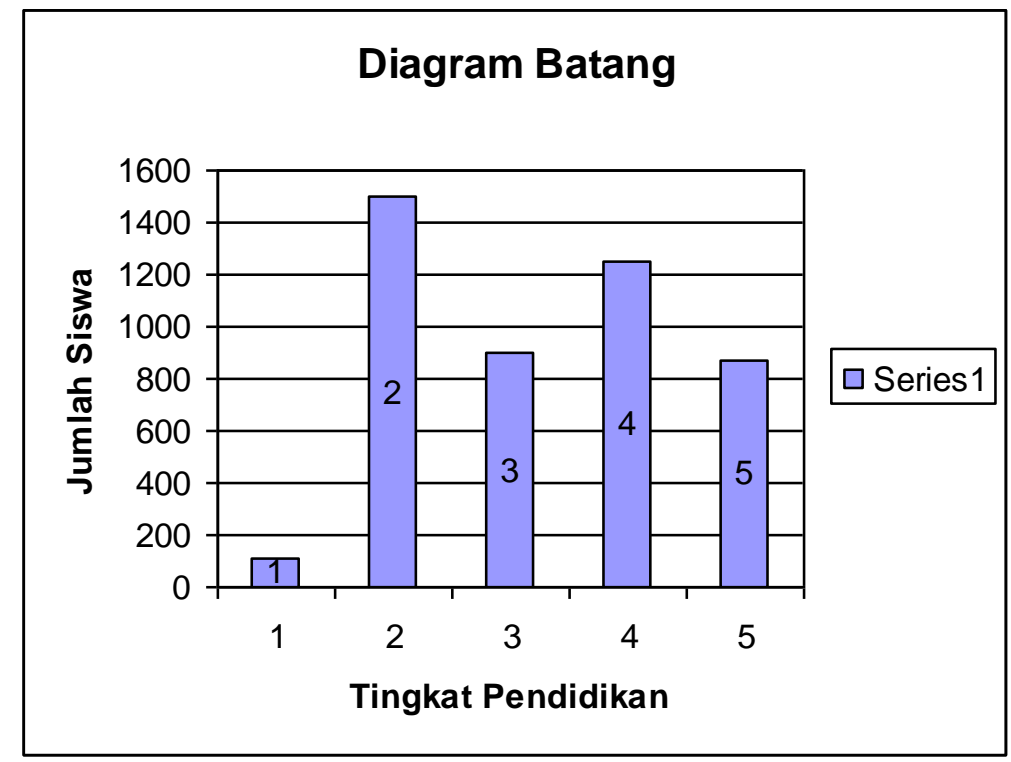

Keterangan $1:$ TK, $2:$ SD, $3:$ SMP, $4:$ SMA, 5 : SMK

Gambar 3 


\section{c. Diagram Garis}

Diagram garis digunakan untuk menggambarkan keadaan yang serba terus atau berkesinambungan. Misalnya produk minyak tiap tahun, jumlah penduduk tiap tahun, keadaan temperatur badan tiap jam dan lain-lain. Seperti diagram batang, disini pun diperlukan sumbu datar dan sumbu tegak, yang saling tegak lurus. Sumbu datar menyatakan waktu sedangkan sumbu tegaknya melukiskan kuantum data dari tiap waktu.

\section{Contoh 3}

Data berikut menyatakan penggunaan barang di sebuah kantor selama tahun 1971 sampai 1980. Data ini dapat dibuatkan dalam diagram garis sebagaimana tertera dalam gambar 4 di bawah ini:

\begin{tabular}{|c|c|}
\hline Tahun & $\begin{array}{c}\text { Jumlah Barang yang } \\
\text { Digunakan }\end{array}$ \\
\hline 1971 & 376 \\
\hline 1972 & 524 \\
\hline 1973 & 412 \\
\hline 1974 & 310 \\
\hline 1975 & 268 \\
\hline 1976 & 476 \\
\hline 1977 & 316 \\
\hline 1978 & 556 \\
\hline 1979 & 585 \\
\hline 1980 & 434 \\
\hline
\end{tabular}

Diagram garis dari data di atas adalah :

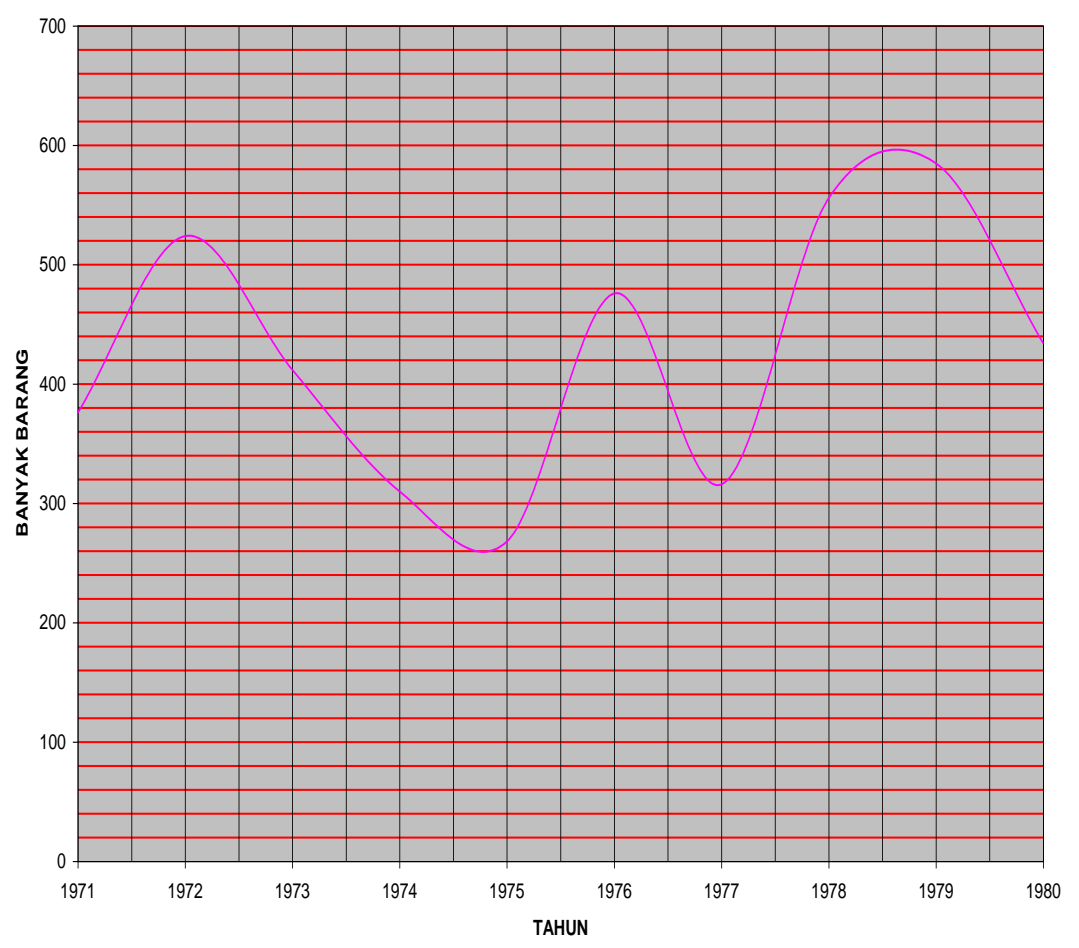

Gambar 4 


\section{d. Diagram Lambang}

Diagram lambang sering dipakai untuk mendapatkan gambaran kasar sesuatu hal dan sebagai alat visual bagi orang awam. Sangat menarik dilihat, lebihlebih jika simbol yang digunakan cukup baik dan menarik. Setiap satuan jumlah tertentu dibuat sebuah simbol sesuai dengan macam datanya. Misalnya untuk data mengenai jiwa, penduduk dan pegawai dibuat gambar orang, satu gambar untuk tiap 5.000 jiwa, untuk data bangunan, gedung sekolah dan lainlain dibuat gambar gedung, satu gedung menyatakan 25 buah, dan masih banyak contoh yang lain.

\begin{tabular}{|c|c|c|}
\hline $\begin{array}{c}\text { Kotak } \\
\text { Suara }\end{array}$ & Lambang & $\begin{array}{c}\text { Jumlah } \\
\text { Kotak }\end{array}$ \\
\hline $\mathrm{A}$
\end{tabular}

Kesulitan yang dihadapi ialah ketika menggambarkan bagian simbol untuk satuan yang tidak penuh. Sebagai contoh untuk melukiskan pegawai di berbagai kantor , diagram simbolnya dapat dilihat di bawah ini:

\begin{tabular}{|c|c|c|c|}
\hline Jawatan & & & Jumlah Pegawai \\
\hline $\mathrm{A}$ & & & 73 \\
\hline $\mathrm{B}$ & $\mathrm{C}$ & & 58 \\
\hline $\mathrm{D}$ & & & 60 \\
\hline
\end{tabular}

\section{e. Diagram lingkaran}

Diagram ini dipakai untuk tujuan membandingkan kuantitas beberapa sektor yang dapat diperbandingkan dalam suatu lingkaran. Tiap sektor menggambarkan kategori data yang kuantitasnya dinyatakan dalam persen untuk menggambarkan besarnya sektor atau juring lingkaran.

Langkah-langkah dalam membuat diagram lingkaran adalah sebagai berikut :

1. Mengubah nilai data absolut ke dalam bentuk persentase untuk masing-masing kategori

2. Mengubah nilai data dalam bentuk persentase ke dalam satuan derajat untuk masing-masing kategori.

3. Buat sebuah lingkaran dan masukan kategori sesuai dengan besarnya derajat yang diperoleh pada langkah kedua. 


\section{Contoh 4}

Jika data dalam contoh 2 di atas disajikan dalam bentuk diagram lingkaran maka langkah-langkah yang harus dilakukan adalah sebagai berikut : mengubah data ke dalam bentuk persentase untuk masing-masing tingkatan sekolah.

$$
\begin{aligned}
& T K=\frac{110}{4630} \times 100 \%=2 \% \\
& S D=\frac{1500}{4630} \times 100 \%=33 \% \\
& S M P=\frac{900}{4630} \times 100 \%=19 \% \\
& S M A=\frac{1250}{4630} \times 100 \%=27 \% \\
& S M K=\frac{870}{4630} \times 100 \%=19 \%
\end{aligned}
$$

Selanjutnya nilai presentase diubah ke dalam satuan derajat untuk masingmasing tingkatan sekolah :

$$
\begin{aligned}
& T K=\frac{2}{100} \times 360^{\circ}=7,2^{0} \\
& S D=\frac{33}{100} \times 360^{\circ}=118,8^{0} \\
& S M P=\frac{19}{100} \times 360^{\circ}=68,4^{0} \\
& S M A=\frac{27}{100} \times 360^{\circ}=97,2^{0} \\
& S M K=\frac{19}{100} \times 360^{\circ}=68,4^{0}
\end{aligned}
$$

Diagram lingkaran yang diperoleh adalah :

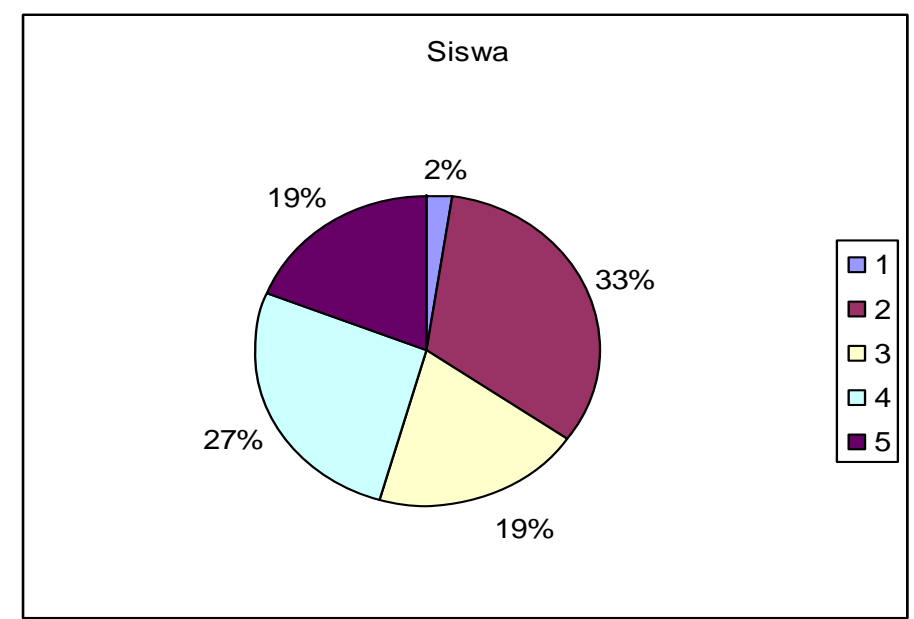




\subsection{LATIHAN SOAL}

1. Jelaskan pengertian sampel acak!

2. Jelaskan 4 skala yang digunakan untuk mengolah data.

3. Jelaskan apa yang dimaksud dengan data primer dan data sekunder!

4. Jelaskan pembagian data menurut sifatnya!

5. Sebutkan dan jelaskan teknik-teknik pengambilan sampel!

6. Berikan masing-masing 3 contoh data kontinu dan data diskrit !

7. Jelaskanlah perbedaan statistik dan statistika

8. Jelaskan pengertian populasi dan sampel

9. Jelaskan pembagian dalam tinjauan statistika

10. Berikan masing-masing 2 contoh data kontinu dan data diskrit

11. Banyak murid di daerah kabupaten Manggarai Barat menurut tingkat sekolah dan jenis kelaminTahun 1990

\begin{tabular}{|l|l|l|l|}
\hline \multirow{2}{*}{$\begin{array}{c}\text { Tingkat } \\
\text { sekolah }\end{array}$} & \multicolumn{2}{|c|}{ Banyak murid } & \multirow{2}{*}{ Jumlah } \\
\cline { 2 - 3 } & Laki-laki & Perempuan & \\
\hline SD & 875 & 687 & 1.562 \\
SMP & 512 & 507 & 1.019 \\
ST & 347 & 85 & 432 \\
SMA & 476 & 342 & 818 \\
AMEA & 316 & 427 & 743 \\
\hline JUMLAH & 2.526 & 2.084 & 4.574 \\
\hline
\end{tabular}

Sajikan data di atas dalam bentuk diagram batang berdasarkan jumlah murid!

\section{DAFTAR PUSTAKA}

Aczel, 1995, Statistical Conceps and applications.

Groeneveld, R., 1988, Introductory Statistical Methods, Iowa State University.

Murray R. Spegel, 1972, Statistics, New York, Mc Graw-Hill Book Co.

Sudjana, 2000, Metode Statistika, Penerbit Tarsito Bandung.

Supranto, 1986, Pengantar Probabilita dan Statistik Induktif, Jilid 2, Penerbit Erlangga.

Wibisono Y., 2005, Metode Statistik, Gadjah Mada University Press, Yogyakarta. 


\section{BAB II \\ DISTRIBUSI FREKUENSI}

\subsection{PENGANTAR}

Dalam bab I, Anda telah mempelajari bagaimana cara mengumpulkan data, jenis-jenis data dan bagaimana cara menyajikan data-data tersebut dalam bentuk diagram. Pada bab ini, Anda akan mempelajari bagaimana menyusun secara sistimatis suatu kumpulan data agar dapat dengan mudah dianalisa. Hal ini menjadi sangat penting ketika Anda menemukan jumlah data yang cukup besar.

Disini hanya dibahas cara penyusunan distribusi frekuensi kuantitatif dan pembuatan grafiknya.

Setelah mempelajari Bab ini, Anda diharapkan dapat menjelaskan pengertian tabel distribusi frekuensi, berbagai macam tabel distribusi frekuensi, serta mampu menyusun tabel distribusi frekuensi dari sekelompok pengamatan dan menyajikan grafik dari data yang disajikan dalam bentuk tabel distribusi frekuensi.

\subsection{URAIAN MATERI}

Susunan dari suatu data disebut distribusi data. Beberapa cara menyusun data adalah sebagai berikut :

a. Distribusi frekuensi kuantitatif : penyusunan data menurut besarnya (kuantitasnya)

b. Distribusi frekuensi kualitatif (kategori) : penyusunan data menurut kualitasnya (kategorial)

c. Runtun waktu (time series) : penyusunan data menurut waktu terjadinya.

Distribusi spasial : penyusunan data menurut tempat geografisnya.

\section{A. Tabel Distribusi Frekuensi}

Tabel distribusi frekuensi adalah suatu bentuk penyajian data dalam bentuk tabel yang mana datanya disajikan dalam bentuk interval dan masingmasing interval mempunyai frekuensinya masing-masing. Apabila kita memiliki data yang banyak sekali jumlahnya maka untuk mempermudah dalam menganalisa perlu dibuat distribusi frekuensi atau tabel frekuensi.

Berikut ini akan disajikan cara membuat distribusi frekuensi :

1. Tentukan banyak dan lebar interval kelas. Hal ini tergantung pada banyak dan besarnya harga-harga yang akan disusun dalam distribusi tersebut. Banyaknya interval kelas yang efisien adalah antara 5 dan 15 . H. A Sturges mengajukan sebuah rumus untuk menghitung banyaknya interval kelas yaitu :

$k=1+3.322 \log n$ dimana $n$ adalah banyaknya data.

Sedangkan lebar interval kelas ditentukan dengan membagi jangkauan (selisih antara harga terbesar dan terkecil) dengan banyak interval kelas yang digunakan.

2. Interval-interval kelas tersebut diletakkan dalam suatu kolom, diurutkan dari interval kelas terendah pada kolom paling atas dan seterusnya. 
3. Data diperiksa dan dimasukan kedalam interval kelas yang sesuai. Banyaknya data yang masuk dalam suatu interval kelas dinamakan frekuensi interval kelas tersebut.

\section{Contoh 1}

Diketahui data tinggi badan $(\mathrm{cm})$ dari 50 orang dewasa sebagai berikut:

$\begin{array}{llllllllll}176 & 167 & 180 & 165 & 168 & 171 & 177 & 176 & 170 & 175 \\ 169 & 171 & 171 & 176 & 166 & 179 & 181 & 174 & 167 & 172 \\ 170 & 169 & 175 & 178 & 171 & 168 & 178 & 183 & 174 & 166 \\ 181 & 172 & 177 & 182 & 167 & 179 & 183 & 185 & 185 & 173 \\ 179 & 180 & 184 & 170 & 174 & 175 & 176 & 175 & 182 & 172\end{array}$

Perhatikan bahwa data terbesar adalah 185 dan data terkecil adalah 165 .

Jangkuan $=185-165=20$

Dengan menggunakan rumus Sturges kita menentukan banyaknya kelas interval :

$$
\begin{aligned}
k= & 1+3.322 \log n \\
& =1+3,322 \log 50 \\
& =
\end{aligned}
$$

Apabila diambil banyaknya interval kelas :

$$
\begin{aligned}
& 6 \text { maka lebar kelas }=\frac{20}{6}=3.3 \\
& 7 \text { maka lebar kelas }=\frac{20}{7}=2.85 \\
& 8 \text { maka lebar kelas }=\frac{20}{8}=2.5
\end{aligned}
$$

Dalam contoh ini diambil banyak interval kelas 7 dengan lebar kelas 3 . Kemudian disusun dalam tabel 2.1 berikut.

Tabel 2.1

\begin{tabular}{|c|c|}
\hline Interval Kelas & Frekuensi \\
\hline $165-167$ & 6 \\
$168-170$ & 7 \\
$171-173$ & 8 \\
$174-176$ & 11 \\
$177-179$ & 7 \\
$180-182$ & 6 \\
$183-185$ & 5 \\
\hline Jumlah & 50 \\
\hline
\end{tabular}




\section{B. Distribusi Frekuensi Relatif dan Kumulatif}

Jika yang diinginkan adalah mengetahui berapa banyak orang yang tinggi badannya lebih dari atau kurang dari suatu harga/nilai tertentu maka distribusi frekuensi diubah menjadi distribusi frekuensi kumulatif. Distribusi frekuensi kumulatif ada dua yaitu distribusi frekuensi kumulatif "Kurang dari " dan distribusi frekuensi kumulatif "Lebih dari “

Dari contoh 2.1 akan dapat disusun distribusi frekuensi kurang dari dan lebih dari sebagai berikut:

Tabel 2.1.a

\begin{tabular}{|c|c|}
\hline Distribusi Frekuensi Kumulatif "kurang dari" \\
\hline Tinggi Badan & Frekuensi \\
\hline Kurang dari 165 & 0 \\
Kurang dari 168 & 6 \\
Kurang dari 171 & 13 \\
Kurang dari 174 & 21 \\
Kurang dari 177 & 32 \\
Kurang dari 180 & 39 \\
Kurang dari 183 & 45 \\
Kurang dari 186 & 50 \\
\hline
\end{tabular}

Tabel 2.1.b

Distribusi Frekuensi Kumulatif "Atau Lebih"

\begin{tabular}{|c|c|}
\hline Tinggi Badan & Frekuensi \\
\hline 165 atau lebih & 50 \\
168 atau lebih & 44 \\
171 atau lebih & 37 \\
174 atau lebih & 29 \\
177 atau lebih & 18 \\
180 atau lebih & 11 \\
183 atau lebih & 5 \\
186 atau lebih & 0 \\
\hline
\end{tabular}

Jika yang diinginkan adalah berapa persen orang yang tinggi badannya antara harga tertentu, lebih dari harga tertentu, ataupun kurang dari suatu harga tertentu, maka distribusi frekuensi diubah menjadi distribusi frekuensi relatif, distribusi frekuensi relatif kumulatif "atau lebih" atau distribusi frekuensi relatif kumulatif "kurang dari".

Cara untuk mengubah distribusi frekuensi menjadi distribusi frekuensi relatif adalah : harga frekuensi pada setiap interval kelas dibagi dengan jumlah total frekuensi, kemudian dikalikan $100 \%$. Distribusi frekuensi relatif untuk data pada contoh 2.1 adalah sebagai berikut: 
Tabel 2.2

Distribusi Frekuensi Relatif

\begin{tabular}{|c|c|}
\hline Interval Kelas & $\mathrm{F}_{\text {rel }}(\%)$ \\
\hline $165-167$ & 12 \\
$168-170$ & 14 \\
$171-173$ & 16 \\
$174-176$ & 22 \\
$177-179$ & 14 \\
$180-182$ & 12 \\
$183-185$ & 10 \\
\hline Jumlah & 100 \\
\hline
\end{tabular}

Tabel 2.2.a

Distribusi Frekuensi Relatif kumulatif "kurang dari"

\begin{tabular}{|c|c|}
\hline Tinggi Badan & $\mathrm{F}_{\text {relatif kum }}(\%)$ \\
\hline Kurang dari 165 & 0 \\
Kurang dari 168 & 12 \\
Kurang dari 171 & 26 \\
Kurang dari 174 & 42 \\
Kurang dari 177 & 64 \\
Kurang dari 180 & 78 \\
Kurang dari 183 & 90 \\
Kurang dari 186 & 100 \\
\hline
\end{tabular}

Tabel 2.2.b

Distribusi Frekuensi Relatif Kumulatif "atau lebih"

\begin{tabular}{|c|c|}
\hline Tinggi Badan & $\mathrm{F}_{\text {relatif kum }}(\%)$ \\
\hline 165 atau lebih & 100 \\
168 atau lebih & 88 \\
171 atau lebih & 74 \\
174 atau lebih & 58 \\
177 atau lebih & 36 \\
180 atau lebih & 22 \\
183 atau lebih & 10 \\
186 atau lebih & 0 \\
\hline
\end{tabular}

\section{Histrogram dan Poligon frekuensi}

Misalkan kita mempunyai sekumpulan data, kemudian data itu disusun dalam tabel distribusi frekuensi. Apabila kita ingin mengambarkan grafik berdasarkan data yang sudah disusun dalam bentuk tabel distribusi frekuensi maka akan diperoleh histogram dan poligon frekuensi. Berikut ini diberikan langkahlangkah dalam menggambarkan grafik histogram dan poligon frekuensi.

1. Buatlah sumbu datar dan sumbu tegak. Sumbu datar memuat bilanganbilangan yang merupakan batas-batas semua kelas interval (bisa juga 
menggunakan titik tengah setiap kelas intervalnya). Sedangkan sumbu tegak memuat nilai frekuensi dari masing - masing kelas interval

2. Untuk kelas interval yang pertama pada sumbu datar dibatasi oleh batas bawah dan batas atasnya. Pada batas bawah dan batas atas masingmasing ditarik garis tegak lurus ke atas sampai menunjukkan bilangan yang sesuai dengan frekuensi pada sumbu tegak. Selanjutnya hubungkan kedua ujungnya sehingga akan terbentuk sebuah batang yang merupakan empat persegi panjang.

3. Ulangi langkah yang kedua untuk interval kelas kedua, ketiga sampai interval kelas yang terakhir, sehingga akan diperoleh batang-batang yang saling berimpit dan grafik inilah yang disebut dengan histogram.

4. Apabila dari grafik histogram ini, titik-titik tengah sisi atas persegi panjang dihubungkan satu sama lain dan hubungkan sisi atas pertama dengan setengah jarak dari panjang kelas yang diukurkan kekiri, batas bawah kelas interval pertama, serta hubungkan sisi atas terakhir dengan setengah jarak dari panjang kelas yang diukurkan kekanan batas atas interval terakhir maka akan diperoleh poligon frekuensi.

Histogram Distribusi Frekuensi

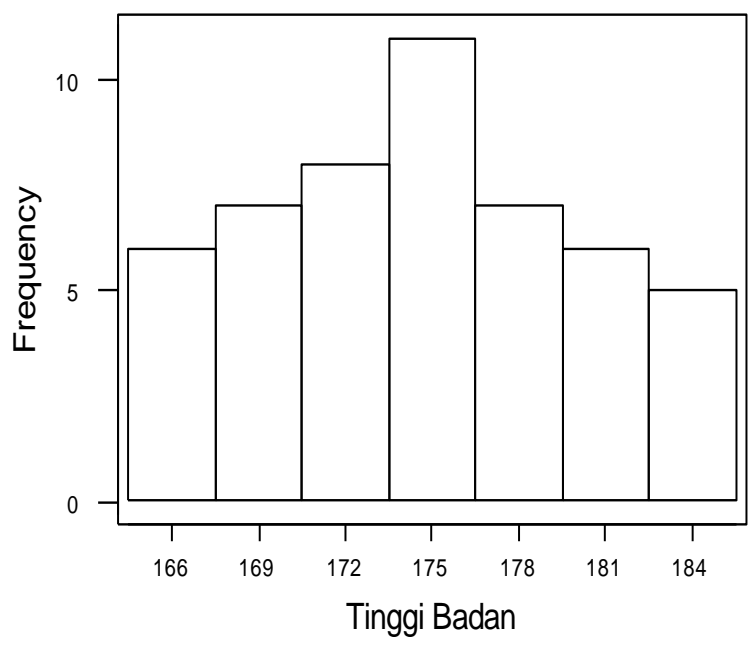


Histogram Distribusi Frekuensi Relatif
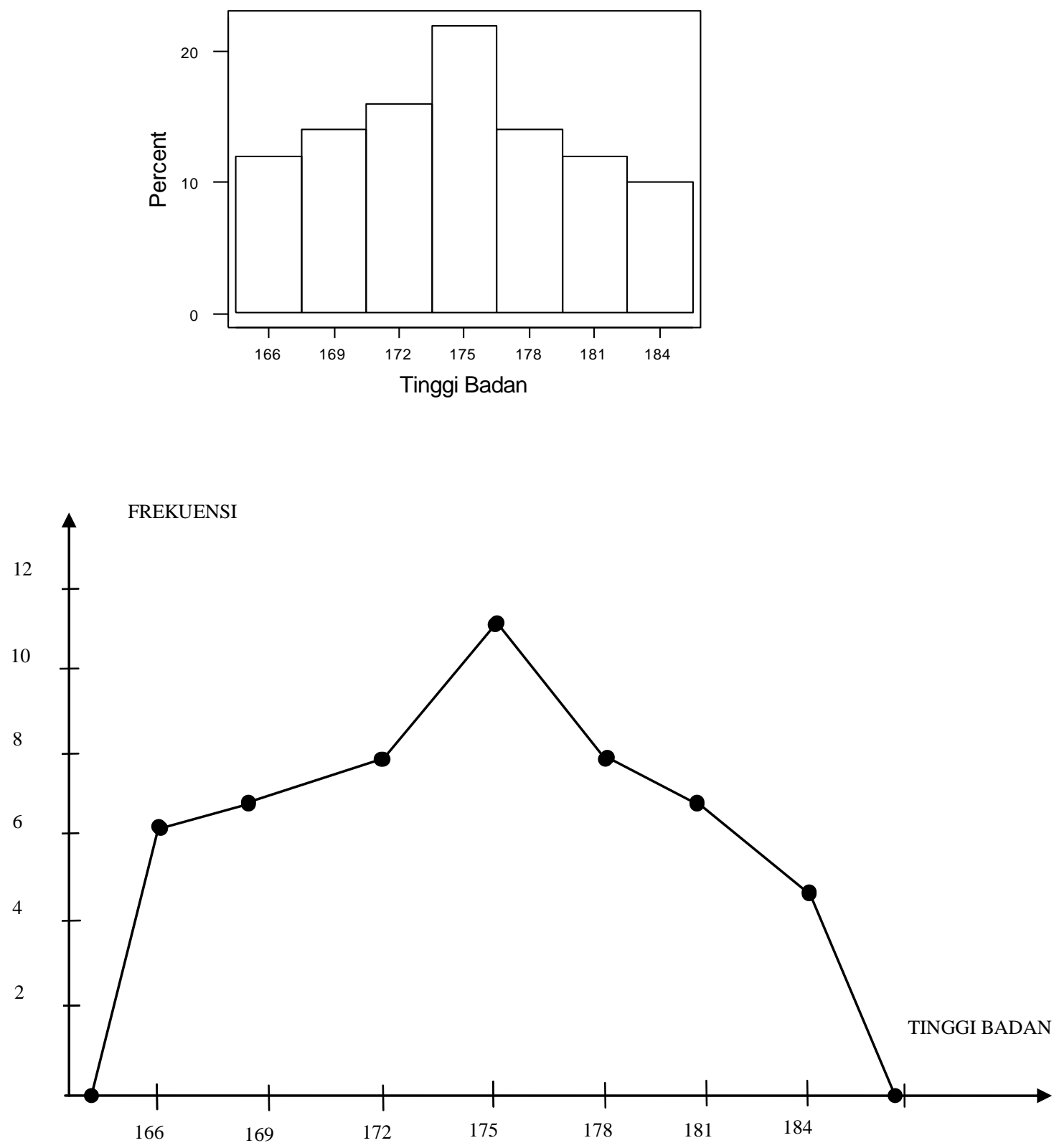

GAMBAR POLIGON DISTRIBUSI FREKUENSI

\section{Ogive}

Misalkan kita mempunyai kumpulan data yang sudah disusun dalam tabel distribusi frekuensi kumulatif, maka dari daftar tersebut dapat digambarkan grafik ogive. Karena tabel distribusi frekuensi kumulatif ada dua macam maka ada dua jenis grafik ogive yaitu ogive positip dan ogive negatif. Grafik ogive positip dibuat berdasarkan tabel distribusi frekuensi kumulatif 'kurang dari" sedangkan grafik ogive negatif dibuat berdasarkan tabel distribusi frekuensi kumulatif "lebih dari”. 
Cara menggambar ogive adalah : gambarkan frekuensi kumulatif dari kelas-kelas yang kurang dari ujung bawah suatu kelas pada sumbu mendatar dan frekuensi kumulatifnya pada sumbu vertikal. Kemudian hubungkan titik-titik yang diperoleh dengan ruas-ruas garis. Dengan demikian akan diperoleh gambar berikut :

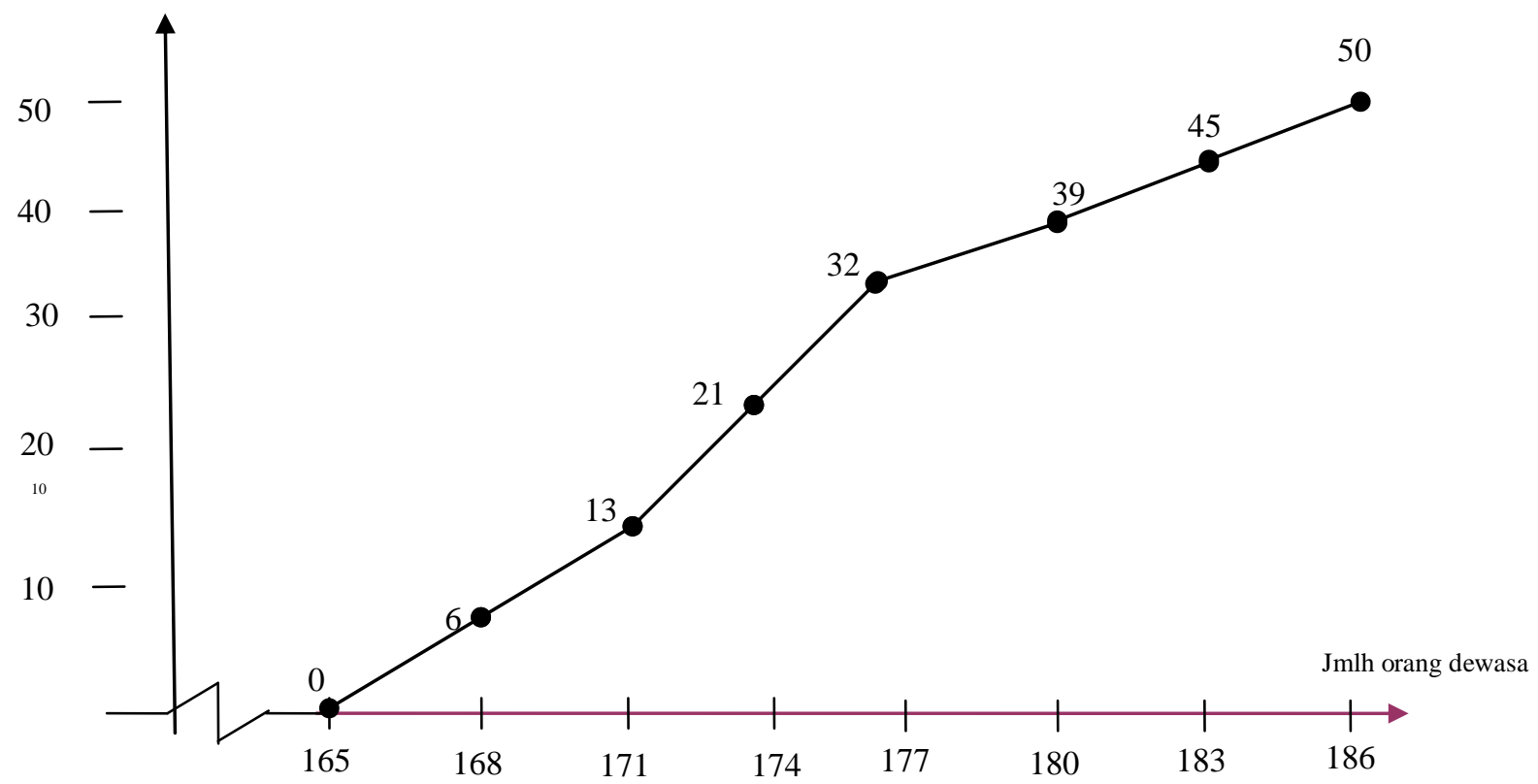

Gambar Grafik Ogive Positif

\subsection{SOAL LATIHAN}

1. Minat olahraga mahasiswa Fakultas Ilmu Sosial dan Politik Undana disajikan dalam tabel berikut ini

\begin{tabular}{|l|c|}
\hline \multicolumn{1}{|c|}{ Olahraga } & Peminat \\
\hline Basket & 35 \\
\hline Renang & 20 \\
\hline Sepak bola & 120 \\
\hline Bulu Tangkis & 40 \\
\hline Tenis Meja & 55 \\
\hline Lain-lain & 10 \\
\hline
\end{tabular}

Dari tabel di atas buatlah :

a). Diagram batang

b). Diagram lingkaran

2. Berikut ini adalah data nilai hasil ujian statistik dasar 75 mahasiswa jurusan Ekonomi :

$\begin{array}{lllllllllll}86 & 75 & 68 & 66 & 60 & 45 & 26 & 82 & 76 & 66 & 72 \\ 73 & 61 & 51 & 28 & 30 & 55 & 62 & 71 & 69 & 80 & 81 \\ 83 & 32 & 56 & 62 & 72 & 68 & 80 & 87 & 85 & 79 & 48 \\ 71 & 65 & 57 & 34 & 39 & 50 & 64 & 70 & 78 & 90 & 70\end{array}$


Berdasarkan data tersebut

a. Buatlah tabel distribusi frekuensi dengan banyaknya kelas interval adalah 8

b. Hitunglah frekuensi relatif untuk tiap-tiap kelas interval

c. Buatlah tabel distribusi frekuensi kumulatif "kurang dari" dan distribusi frekuensi kumulatif "lebih dari" serta ogivenya.

d. Buatlah histogram dari tabel distribusi frekuensi.

3. Nilai mata kuliah matematika dari mahasiswa program S-1 Jurusan pendidikan Matematika FKIP Undana disajikan dalam tabel distribusi frekuensi berikut ini

\begin{tabular}{|c|c|}
\hline Nilai Ujian & Frekuensi \\
\hline $61-65$ & 4 \\
\hline $66-70$ & 9 \\
\hline $71-75$ & 11 \\
\hline $76-80$ & 2 \\
\hline $81-85$ & 4 \\
\hline $86-90$ & 7 \\
\hline $91-95$ & 3 \\
\hline
\end{tabular}

Dengan menggunakan data dalam tabel diatas, hitunglah :

a. Persentase dari mahasiswa yang memperoleh nilai kurang dari 71

b. Persentase dari mahasiswa yang memperoleh nilai 81 atau lebih

c. Jumlah mahasiswa yang memperoleh nilai paling tinggi 80

d. Persentase dari mahasiswa yang memperoleh nilai dalam interval $86-90$

4. Data berikut menyatakan nilai ujian akhir semester dari 40 mahasiswa yang mengikuti ujian Metode Statistik Program studi Pendidikan matematika FKIP UNDANA adalah:

$\begin{array}{llllllllll}65 & 72 & 67 & 82 & 72 & 91 & 67 & 73 & 71 & 70 \\ 85 & 87 & 68 & 86 & 83 & 90 & 74 & 89 & 75 & 61 \\ 65 & 76 & 71 & 65 & 91 & 79 & 75 & 69 & 66 & 85 \\ 95 & 74 & 73 & 68 & 86 & 90 & 70 & 71 & 88 & 68\end{array}$

Sajikan data di atas dalam bentuk table distribusi frekuensi dengan banyaknya kelas yang digunakan adalah 7 kelas!

5. Sajikan data dalam nomor 1 dalam bentuk table distribusi frekuensi relative !

6. Sajikan data dalam nomor 1 dalam bentuk table distribusi frekuensi kumulatif "kurang dari"

7. Sajikan data dalam nomor 1 dalam bentuk table distribusi frekuensi kumulatif "atau lebih"

8. Sajikan data dalam nomor 1 dalam bentuk table distribusi frekuensi relative kumulatif "kurang dari"

9. Sajikan data dalam nomor 1 dalam bentuk table distribusi frekuensi relative kumulatif "atau lebih" 


\section{DAFTAR PUSTAKA}

Aczel, 1995, Statistical Conceps and applications.

Groeneveld, R., 1988, Introductory Statistical Methods, Iowa State University.

Herrhyanto N., Hamid, H. M. A., 2007, Statistika Dasar, Universitas Terbuka, Cetakan ke 15, Jakarta.

Murray R. Spegel, 1972, Statistics, New York, Mc Graw-Hill Book Co.

Sudjana, 2000, Metode Statistika, Penerbit Tarsito Bandung.

Supranto, 1986, Pengantar Probabilita dan Statistik Induktif, Jilid 2, Penerbit Erlangga.

Wibisono Y., 2005, Metode Statistik, Gadjah Mada University Press, Yogyakarta. 


\section{BAB III \\ UKURAN GEJALA PUSAT DAN UKURAN LETAK}

\subsection{PENGANTAR}

Pengolahan data merupakan salah satu tindak lanjut setelah kita menyajikan data yang kita miliki dalam bentuk berbagai diagram dan tabel. Ada banyak ukuran statistik yang digunakan untuk menjelaskan dan menguraikan datadata yang berhasil dikumpulkan. Karakteristik yang dimaksud umumnya berbentuk parameter misalnya rata-rata, persentase, median, maupun sifat-sifat lain yang dimiliki oleh data tersebut. Dalam bagian ini, penulis akan menyajikan beberapa ukuran atau ukuran yang banyak dipakai sebagai alat atau sebagai parameter untuk dapat digunakan sebagai bahan pegangan dalam menafsirkan suatu gejala atau suatu yang akan diteliti berdasarkan hasil pengolahan data yang dikumpulkan.

Berbagai ukuran pusat dan ukuran letak yang akan dikaji dalam bagian ini adalah Nilai rata-rata, Median, Modus, Kuartil, Desil, Persentil. Dalam pembahasannya nanti akan diuraikan secara terpisah untuk perhitungan ukuran pusat dan ukuran letak pada data tunggal dan data berkelompok

Setelah mempelajari bab 3 mahasiswa diharapkan dapat memahami arti dan kegunaan ukuran pemusatan, terutama mahasiswa diharapkan dapat : membedakan kegunaan nilai rata-rata hitung dengan nilai rata-rata ukur, menghitung nilai rata-rata hitung dari data tunggal dan data berkelompok, menghitung median dari data tunggal dan data berkelompok, menghitung modus dari data tunggal dan data berkelompok, menghitung kuartil dari data tunggal dan data berkelompok.

\subsection{URAIAN MATERI}

\section{A. Rata-Rata Atau Rata-Rata Hitung}

Jika ada lima nilai ujian dari lima orang mahasiswa untuk mata kuliah statistika berbentuk : 70, 69, 45, 80 dan 56, maka dalam simbol ditulis : $\mathrm{x}_{1}=70, \mathrm{x}_{2}$ $=69, x_{3}=45, x_{4}=80$ dan $x_{5}=56$. dalam hal ini $\mathrm{n}=5$, yang menyatakan sebuah sample berukuran 5. Rata-rata, atau rata-rata hitung, untuk data kuantitatif yang terdapat dalam sebuah sampel dihitung dengan jalan membagi jumlah nilai data oleh banyak data. Simbol rata-rata untuk sampel ialah $\bar{X}$. Sedangkan rata-rata untuk populasi dipakai simbol $\mu$. Jadi $\bar{X}$ adalah statistik sedangkan $\mu$ adalah parameter untuk menyatakan rata-rata. Rumus untuk rata-rata $\bar{X}$ adalah :

$$
\bar{X}=\frac{\mathrm{x}_{1}+\mathrm{x}_{2}+\ldots \ldots+\mathrm{x}_{\mathrm{n}}}{\mathrm{n}} \text { atau } \bar{X}=\frac{\sum_{\mathrm{i}=1}^{\mathrm{n}} \mathrm{x}_{\mathrm{i}}}{\mathrm{n}}
$$

atau lebih sederhana lagi ditulis

$$
\bar{X}=\frac{\sum_{\mathrm{i}=1}^{\mathrm{n}} \mathrm{x}_{\mathrm{i}}}{\mathrm{n}}
$$


$\sum_{\mathrm{i}=1}^{\mathrm{n}} \mathrm{x}_{\mathrm{i}}$ menyatakan jumlah semua harga $\mathrm{x}$ yang ada dalam kumpulan data.

Untuk ke lima nilai ujian di atas, nilai rata-ratanya ialah :

$$
\bar{X}=\frac{70+69+45+80+56}{5}=64
$$

\section{Contoh 1}

Jika ada lima mahasiswa mendapat nilai 70 , enam mendapat 69 , yiga mendapat 45 dan masing-masing seorang mendapat nilai 80 dan 56, maka penyajian data baiknya disajikan sebagai berkut :

\begin{tabular}{|c|c|}
\hline $\mathrm{x}_{\mathrm{i}}$ & $\mathrm{f}_{\mathrm{i}}$ \\
\hline 70 & 5 \\
69 & 6 \\
45 & 3 \\
80 & 1 \\
56 & 1 \\
\hline
\end{tabular}

$\mathrm{x}_{\mathrm{i}}$ menyatakan nilai ujian, dan

$f_{i}$ menyatakan frekuensi untuk nilai xi yang bersesuaian, misalnya : $\mathrm{f}_{1}=5$ untuk $\mathrm{x}_{1}=70$, $\mathrm{f}_{2}=6$ untuk $\mathrm{x}_{2}=69$ dan seterusnya

Untuk data berbentuk demikian, rumus rata-ratanya adalah :

$$
\bar{X}=\frac{\sum \mathrm{f}_{\mathrm{i}} \mathrm{x}_{\mathrm{i}}}{\sum \mathrm{f}_{\mathrm{i}}}
$$

Yaitu jumlah semua hasil kali antara frekuensi dan nilai data dibagi dengan jumlah frekuensi.

\begin{tabular}{|c|c|c|c|}
\hline $\mathrm{x}_{\mathrm{i}}$ & $\mathrm{f}_{\mathrm{i}}$ & $\mathrm{f}_{\mathrm{i}} \mathrm{x}_{\mathrm{i}}$ & Dari tabel didapat \\
\hline 70 & 5 & 350 & $\sum f_{i}=16$ dan \\
\hline 69 & 6 & 414 & $\sum f_{i} x_{i}=1035$ \\
\hline 45 & 3 & 135 & sehingoa \\
\hline 80 & 1 & 80 & r \\
\hline 56 & 1 & 56 & $\bar{x}=\frac{\sum J_{i} \wedge_{i}}{\sum f}$ atau $\bar{x}=\frac{10 J 5}{16}=64,6$ \\
\hline Jumlah & 16 & 1035 & \\
\hline
\end{tabular}

Untuk contoh diatas, dianjurkan dibuat tabel penolong seperti berikut :

Nilai rata-rata ujian statistik untuk ke 16 mahasiswa itu adalah 64,6.

Selanjutnya kita juga dapat menentukan rata-rata gabungan, yaitu ratarata dari beberapa sub sampel lalu dijadikan satu. Kalau ada $k$ buah sub sampel lalu dijadikan satu. Kalau ada $k$ buah sub sampel masing-masing dengan keadaan berikut :

Sub sampel 1 : berukuran $\mathrm{n}_{1}$ dengan rata-rata $\bar{x}_{1}$

Sub sampel 2 : berukuran $\mathrm{n}_{2}$ dengan rata-rata $\bar{x}_{2}$

Sub sampel $k$ : berukuran $\mathrm{n}_{\mathrm{k}}$ dengan rata-rata $\bar{x}_{k}$ 
Maka rata-rata gabungan dari k buah sub sampel tersebut : $\quad \bar{X}=\frac{\sum n_{i} \bar{x}_{i}}{\sum n_{i}}$

\section{Contoh 2}

Tiga sub sampel masing-masing berukuran 10, 6 dan 8 sedangkan rata-ratanya masing-masing 145, 118 dan 162.

Adalah salah jika rata-rata gabungan dihitung dengan rumus :

$$
\bar{x}=\frac{145+118+162}{3}=141,7
$$

Karena ukuran sampel untuk masing-masing sub sampel berbeda. Dengan demikian untuk menghitung rata-rata dari data diatas, maka dapat dihitung dengan rumus berikut.

$$
\bar{X}=\frac{(10)(145)+(6)(118)+(18)(162)}{10+6+8}=143,9
$$

Untuk data yang telah disusun dalam daftar distribusi frekuensi, rataratanya dihitung dengan rumus :

$$
\bar{X}=\frac{\sum f_{i} x_{i}}{\sum f_{i}}
$$

Dimana $x_{i}$ menyatakan tanda kelas interval dan $f_{i}$ menyatakan frekuensi yang sesuai dengan tanda kelas $x_{i}$.

\section{Contoh 3}

Hitung rata-rata untuk nilai ujian statistika yang terdapat dalam daftar dibawah ini.

\begin{tabular}{|c|c|c|c|}
\hline NILAI UJIAN & FREK. $\left(\mathrm{f}_{\mathrm{i}}\right)$ & TANDA KEL. $\left(\mathrm{x}_{\mathrm{i}}\right)$ & $\left(\mathrm{f}_{\mathrm{i}} \mathrm{x}_{\mathrm{i}}\right)$ \\
\hline $31-40$ & 1 & 35,5 & 35,5 \\
$41-50$ & 2 & 45,5 & 91,0 \\
$51-60$ & 5 & 55,5 & 277,5 \\
$61-70$ & 15 & 65,5 & 982,5 \\
$71-80$ & 25 & 75,5 & $1.887,5$ \\
$81-90$ & 20 & 85,5 & $1.710,0$ \\
$91-100$ & 12 & 95,5 & $1.146,0$ \\
\hline JUMLAH & 80 & - & $6.130,0$ \\
\hline
\end{tabular}

Dari tabel di atas di dapat: $\sum f_{i}=80$ dan $\sum f_{i} x_{i}=6130,0$.

Rata-rata nilai ujian statistika : $\quad \bar{X}=\frac{6130,0}{80}=76,62$ 


\section{B. Rata-Rata Ukur}

Jika perbandingan tiap dua data berurutan tetap atau hampir tetap, ratarata ukur lebih baik dipakai dari pada rata-rata hitung, apabila dikehendaki rataratanya. Untuk data bernilai $x_{1}, x_{2}, \ldots, x_{n}$ maka rata-rata ukur $\mathrm{U}$ didefenisikan sebagai

$$
U=\sqrt[n]{x_{1} \cdot x_{2} \cdot x_{3} \ldots \ldots \ldots x_{n}}
$$

Yaitu akar pangkat $n$ dari hasil kali $x_{1}, x_{2}, \ldots, x_{n}$.

\section{Contoh 4}

Rata-rata ukur data $x_{1}=2, x_{2}=4$ dan $x_{3}=8$ adalah

$U=\sqrt[3]{2 \times 4 \times 8}=4$

Untuk bilangan-bilangan bernilai besar, lebih baik digunakan logaritma :

$$
\log U \frac{\sum \log x_{i}}{n}
$$

Yakni logaritma rata-rata ukur $U$ sama dengan jumlah logaritma tiap data dibagi oleh banyak data. Rata-rata ukur $U$ akan didapat dengan jalan mencari kembali logaritmanya.

\section{Contoh 5}

Diambil $x_{1}=2, x_{2}=4$ dan $x_{3}=8$ maka $\log 2=0,3010 ; \log 4=0,6021$ dan $\log 8=$ 0,9031

$$
\begin{aligned}
& \log U=\frac{\log 2+\log 4+\log 8}{3} \text { atau } \\
& \log U=\frac{0,3010+0,6021+0,9031}{3}=0,6021
\end{aligned}
$$

Sehingga setelah dicari kembali dari daftar logaritma, rata-rata akhir $U=4$.

Untuk fenomena yang bersifat tumbuh dengan syarat-syarat tertentu, seperti pertumbuhan penduduk, bakteri dan lain-lain, sering digunakan rumus yang mirip rata-rata ukur ialah :

$$
P_{t}=P_{0}\left(1+\frac{\bar{x}}{100}\right)^{t}
$$

dengan :

$\mathrm{P}_{0}=$ keadaan awal atau permulaan

$\mathrm{P}_{\mathrm{t}}=$ keadaan akhir

$\bar{x}=$ rata-rata pertumbuhan setiap waktu

$\mathrm{t}=$ satuan waktu yang digunakan 


\section{Contoh 6}

Penduduk Indonesia pada akhir tahun 1946 ada 60 juta sedangkan akhir tahun 1956 mencapai 78 juta. Untuk menentukan laju rata-rata pertumbuhan penduduk tiap tahun, dipakai rumus di atas dengan $\mathrm{t}=10, \mathrm{P}_{0}=60$ dan $\mathrm{P}_{\mathrm{t}}=78$.

Maka didapat :

$$
\begin{aligned}
& 78=60\left(1+\frac{\bar{x}}{100}\right)^{10} \text { atau } \\
& \log 78=\log 60+10 \log \left(1+\frac{\bar{x}}{100}\right) \text { atau } \\
& 1,8921=1,7782+(10) \cdot \log \left(1+\frac{\bar{x}}{100}\right) \text { menghasilkan } \\
& \left(1+\frac{\bar{x}}{100}\right)=1,0267 \longrightarrow \bar{x}=2,67
\end{aligned}
$$

Laju rata-rata pertumbuhan penduduk adalah 2,67\% tiap tahun.

Untuk data yang telah disusun dalam tabel distribusi frekuesi rata-rata ukurnya dihitung dengan rumus :

$$
\log U=\frac{\sum\left(f_{i} \log x_{i}\right)}{\sum f_{i}}
$$

dengan $x_{i}$ menyatakan tanda kelas, $f_{i}=$ frekuensi yang sesuai dengan $x_{i}$ dan harga rata-rata ukur $U$ dicari kembali dari $\log U$.

\section{Rata-Rata Harmonik}

Untuk data $x_{1}, x_{2}, \ldots, x_{n}$ dalam sebuah sampel berukuran $n$, maka rata-rata harmonik ditentukan oleh :

$$
H=\frac{n}{\sum\left(\frac{1}{x_{i}}\right)}
$$

$$
\text { atau lengkapnya } H=\frac{n}{\frac{1}{x_{1}}+\frac{1}{x_{2}}+\ldots \ldots+\frac{1}{x_{n}}}
$$

\section{Contoh 7}

Rata-rata harmonik untuk kumpulan data : 3,5,6,6,7,10,12, dengan $n=7$ ialah :

$$
H=\frac{7}{\frac{1}{3}+\frac{1}{5}+\frac{1}{6}+\frac{1}{6}+\frac{1}{7}+\frac{1}{10}+\frac{1}{12}}=5,87
$$

Untuk data dalam daftar distribusi frekuensi, maka rata-rata harmonik dihitung dengan rumus : 


$$
H=\frac{\sum f_{i}}{\sum\left(f_{i} / x_{i}\right)}
$$

dengan $x_{i}=$ tanda kelas interval dan $f_{i}=$ frekuensi yang sesuai dengan tanda kelas $x_{i}$.

\section{Contoh 8}

Nilai ujian dalam daftar distribusi frekuensi berikut :

\begin{tabular}{|c|c|c|c|}
\hline NILAI UJIAN & $\mathrm{f}_{\mathrm{i}}$ & $\mathrm{x}_{\mathrm{i}}$ & $f_{i} / x_{i}$ \\
\hline $31-40$ & 1 & 35,5 & 0,0282 \\
$41-50$ & 2 & 45,5 & 0,0440 \\
$51-60$ & 5 & 55,5 & 0,0901 \\
$61-70$ & 15 & 65,5 & 0,2290 \\
$71-80$ & 25 & 75,5 & 0,3311 \\
$81-90$ & 20 & 85,5 & 0,2339 \\
$91-100$ & 12 & 95,5 & 0,1256 \\
\hline Jumlah & 80 & - & 1,0809 \\
\hline
\end{tabular}

Dari tabel didapat $\sum\left(f_{i} / x_{i}\right)=1,0819$ dan $\sum f_{i}=80$, sehingga diperoleh :

$$
H=\frac{80}{1,0819}=73,94
$$

Rata-rata harmonik untuk nilai ujian itu adalah $=73,94$.

\section{Modus}

Untuk menyatakan fenomena yang paling banyak terjadi atau paling banyak terdapat digunakan ukuran modus singkat Mo. Ukuran ini juga dalam keadaan tidak disadari sering dipakai untuk menentukan "rata-rata" data kualitatif.

Modus untuk data kuantitatif ditentukan dengan jalan menentukan frekuensi terbanyak diantara data itu.

\section{Contoh 9}

Terdapat sampel dengan nilai-nilai data : $12,34,14,34,28,34,34,28$, 14. Dalam tabel dapat disusun seperti dibawah ini :

\begin{tabular}{|c|c|}
\hline $\mathrm{x}_{\mathrm{i}}$ & $\mathrm{f}_{\mathrm{i}}$ \\
\hline 12 & 1 \\
14 & 2 \\
28 & 2 \\
34 & 4 \\
\hline
\end{tabular}

Frekuensi terbanyak ,ialah $\mathrm{f}=4$ terjadi untuk data bernilai 34. maka modus Mo adalah 34 . 
Jika data kuantitatif telah disusun dalam daftar distribusi frekuensi, modusnya dapat ditentukan dengan rumus :

$$
M o=b+p\left(\frac{b_{1}}{b_{1}+b_{2}}\right)
$$

dengan :

$\mathrm{b}=$ batas bawah kelas modus, ialah kelas interval dengan frekuensi terbanyak.

$\mathrm{p}=$ panjang kelas modus

$\mathrm{b}_{1}=$ frekuensi kelas modus dikurang frekuensi kelas interval dengan tanda kelas yang lebih kecil sebelum tanda kelas modus.

$\mathrm{b}_{2}=$ frekuensi kelas modus dikurang frekuensi kelas interval dengan tanda kelas yang lebih besar sesudah tanda kelas modus.

Jika rumus di atas digunakan untuk mencari modus Mo dari data dalam table distribusi frekuensi seperti dibawah ini, maka diperoleh :

\begin{tabular}{|c|c|}
\hline NILAI & $\mathrm{f}_{\mathrm{i}}$ \\
UJIAN & \\
\hline $31-40$ & 1 \\
$41-50$ & 2 \\
$51-60$ & 5 \\
$61-70$ & 15 \\
$71-80$ & 25 \\
$81-90$ & 20 \\
$91-100$ & 12 \\
\hline Jumlah & 80 \\
\hline
\end{tabular}

1. kelas modus $=$ kelas kelima

2. $b=70,5$

3. $b_{1}=25-15=10$

4. $b_{2}=25-20=5$

5. $\mathrm{p}=10$

$$
\begin{aligned}
& \text { Mo }=70,5+(10)\left(\frac{10}{10+5}\right) \\
& \text { Mo }=77,17
\end{aligned}
$$

Modus, dibandingkan dengan ukuran lainnya, tidak tunggal adanya. Ini berarti sekumpulan data bisa mempunyai lebih dari sebuah modus.

\section{a. Median}

Median menentukan letak data setelah data itu disusun menurut ukuran nilainya. Kalau nilai median sama dengan Me, maka 50\% dari data-data hargaharganya paling tinggi sama dengan Me sedangkan $50 \%$ lagi harga-harganya paling rendah sama dengan Me. Jika banyak data ganjil, maka median Me, setelah data disusun menurut nilainya, merupakan data paling tengah.

\section{Contoh 10}

Sampel dengan data : 4, 12, 5, 7, 8, 10,10 , setelah disusun menurut nilainya menjadi : 4, 5, 7, 8, 10,10, 12. Data paling tengah bernilai 8 . Jadi $\mathrm{Me}=8$.

Untuk sampel berukuran genap, setelah data disusun menurut urutan nilainya, mediannya sama dengan rata-rata hitung dua data tengah. 


\section{Contoh 11}

Diberikan sampel dengan data : 12, 7, 8, 14, 16, 19, 10, 8. setelah disusun menurut nilainya menjadi : $7,8,8,10,12,14,16,19$. Data tengahnya ialah 10 dan 12; sehingga median $\mathrm{Me}=1 / 2(10+12)=11$.

Untuk data yang telah disusun dalam daftar distribusi frekuensi, mediannya dihitung dengan rumus :

$$
M e=b+p\left(\frac{1 / 2 n-F}{f}\right)
$$

dengan :

$\mathrm{b}=$ batas bawah kelas median, ialah kelas dimana median akan terletak.

$\mathrm{p}=$ panjang kelas median.

$\mathrm{n}=$ ukuran sampel atau banyak data

$\mathrm{F}=$ jumlah semua frekuensi dengan tanda kelas lebih kecil dari tanda kelas median.

$\mathrm{f}=$ frekuensi kelas median.

\section{Contoh 12}

Jika untuk nilai ujian 80 mahasiswa akan dihitung mediannya dengan menggunakan daftar berikut maka ditempuh dengan cara sebagai berikut :

\begin{tabular}{|c|c|}
\hline NILAI & $\mathrm{f}_{\mathrm{i}}$ \\
\hline $31-40$ & 1 \\
$41-50$ & 2 \\
$51-60$ & 5 \\
$61-70$ & 15 \\
$71-80$ & 25 \\
$81-90$ & 20 \\
$91-100$ & 12 \\
\hline Jumlah & 80 \\
\hline
\end{tabular}

Setengah dari seluruh data ada 40 buah. Jadi median akan terletak dikelas interval kelima, karena sampai dengan ini jumlah frekuensi sudah lebih dari 40.

Dari kelas median ini didapat :

$\mathrm{b}=70,5 ; \mathrm{p}=10$ dan $\mathrm{f}=25$.

Adapun $\mathrm{F}=1+2+5+15=23$, sehingga

$$
M e=70,5+(10)\left(\frac{40-23}{25}\right)=77,3
$$

Ada $50 \%$ data yang bernilai kurang dari 77,3 dan setengahnya lagi bernilai lebih dari 77,3 .

Dari data tentang nilai ujian 80 mahasiswa, telah didapat rata-rata $\bar{x}=$ 76,62 , modus $\mathrm{Mo}=77,17$ dan median $\mathrm{Me}=77,73$. Kita lihat bahwa harga statistik tersebut berlainan. Ketiga nilai yakni : rata-rata, median dan modus akan sama bila kurva halusnya simetrik. Untuk fenomena dengan kurva halus positif atau negatif, hubungan empirik yang berikut dapat diandalkan :Rata - rata - Mo $=3($ Rata - rata - Me $)$ 


\section{b. Kuartil, Desil dan Persentil}

Jika sekumpulan data dibagi menjadi empat bagian yang sama banyak, sesudah disusn menurut urutan nilainya, maka bilangan pembaginya disebut kuartil. Ada tiga buah kuartil, ialah kuartil pertama, kuartil kedua dan kuartil ketiga yang masing-masing disingkat dengan $\mathrm{K}_{1}, \mathrm{~K}_{2}, \mathrm{~K}_{3}$. Pemberian nama ini dimulai dari nilai kuartil paling kecil.

Untuk menentukan nilai kuartil caranya adalah :

1. susun data menurut urutan nilainya

2. tentukan letak dari kelas kuartil ke-i

3. tentukan nilai kuartil

Letak kuartil ke-i diberi lambang $\mathrm{K}_{\mathrm{i}}$, ditentukan oleh rumus :

$$
\begin{aligned}
& \text { Letak } \mathrm{K}_{\mathrm{i}}=\text { data } \mathrm{ke} \frac{\mathrm{i}(\mathrm{n}+1)}{4} \\
& \text { dengan } \mathrm{i}=1,2,3 .
\end{aligned}
$$

\section{Contoh 13}

Sampel dengan data 75, 82, 66, 57, 64, 56, 92, 94, 86, 52, 60,70, setelah disusun menjadi 52, 56, 57, 60, 64, 66, 70, 75, 82, 86, 92, 94 .

Letak $\mathrm{K}_{1}=$ data ke $\frac{12+1}{4}=$ data ke-31/4, yaitu antara data ketiga dan data ke-4 seperempat jauh dari data ke-3.

Nilai $K_{1}=$ data ke-3 + 1/4 (data ke-4 - data ke-3)

$$
\mathrm{K}_{1}=57+1 / 4(60-57)=573 / 4
$$

Letak $\mathrm{K}_{3}=$ data ke- $\frac{3(12+1)}{4}=$ data ke-93/4. Dengan cara seperti di atas, nilai $\mathrm{K}_{3}$ dapat ditentukan ialah :

$$
\begin{aligned}
& \mathrm{K}_{3}=\text { data ke- } 9+3 / 4(\text { data ke-10 }- \text { data ke- } 9) \\
& \mathrm{K}_{3}=82+(3 / 4)(86-82)=85
\end{aligned}
$$

Untuk data yang telah disusun dalam tabel distribusi frekuensi, kuartil $\mathrm{K}_{\mathrm{i}}(1,2,3)$ dihitung dengan rumus :

$$
\mathrm{K}_{\mathrm{i}}=\mathrm{b}+\mathrm{p}\left(\frac{\frac{\mathrm{in}}{4}+\mathrm{F}}{\mathrm{f}}\right) \text {, dengan } \mathrm{i}=1,2,3
$$

dengan

$\mathrm{b}=$ batas bawah kelas $\mathrm{K}_{\mathrm{i}}$, ialah kelas interval dimana $\mathrm{K}_{\mathrm{i}}$ akan terletak.

$\mathrm{p}=$ panjang kelas $\mathrm{K}_{\mathrm{i}}$

$\mathrm{F}=$ jumlah frekuensi dengan tanda kelas lebih kecil dari tanda kelas $\mathrm{K}_{\mathrm{i}}$

$\mathrm{f}=$ frekuensi kelas $\mathrm{K}_{\mathrm{i}}$ 


\section{Contoh 14}

Kembali pada hasil ujian 80 mahasiswa seperti dalam tabel dibawah ini; maka untuk menentukan kuartil ketiga $\mathrm{K}_{3}$ terletak dalam kelas interval keenam, dan kelas ini merupakan kelas $\mathrm{K}_{3}$. Dari kelas $\mathrm{K}_{3}$ ini didapatlah $\mathrm{b}=80,5 ; \mathrm{p}=10 ; \mathrm{f}=20$ dan $F=1+2+5+15+25=48$. Dengan $i=3$ dan $n=80$ dan dengan rumus di atas maka diperoleh :

$$
K_{3}=80,5+10\left(\frac{\frac{3 \times 80}{4}-48}{20}\right)
$$

$$
=86,5
$$

\begin{tabular}{|c|c|}
\hline NILAI UJIAN & $\mathrm{f}_{\mathrm{i}}$ \\
\hline $31-40$ & 1 \\
$41-50$ & 2 \\
$51-60$ & 5 \\
$61-70$ & 15 \\
$71-80$ & 25 \\
$81-90$ & 20 \\
$91-100$ & 12 \\
\hline Jumlah & 80 \\
\hline
\end{tabular}

Ini berarti ada $75 \%$ mahasiswa mendapat nilai ujian paling tinggi 86,5 , sedangkan $25 \%$ lagi mendapat nilai paling rendah 86,5.

Jika kumpulan data itu dibagi menjadi 10 bagian yang sama, maka didapat sembilan pembagi dan tiap pembagi dinamakan desil. Karenanya ada sembilan buah desil, ialah desil pertama, desil kedua,........, desil kesembilan yang disingkat D1, D2,..... D9. Penentuan nilai dari desil-desil ini dapat dilakukan dengan tahapan sebagai berikut :

1. susun data menurut urutan nilainya

2. tentukan letak desil

3. tentukan nilai desil

Letak desil ke-i, diberi lambang $D_{i}$ yang ditentukan oleh rumus :

\section{Contoh 15}

$$
\text { Letak } D_{i}=\text { data } k e-\frac{i(n+1)}{10} ; i=1,2, \ldots, 9 .
$$

Untuk data yang telah disusun dalam contoh terdahulu, ialah : 52, 56, 57, 60, 64, $66,70,75,82,86,92,94$, maka letak $\mathrm{D}_{7}=$ data ke- $\frac{7(12+1)}{10}=$ data ke $-9,1$

Sedangkan nilai $\mathrm{D}_{7}$ adalah data ke-9 + $(0,1)($ data ke-10 - data ke-9) atau

$$
D_{7}=82+0,1(86-82)=82,4
$$


Untuk data berkelompok yang telah disusun dalam tabel distribusi frekuensi, nilai desil dapat dihitung dengan rumus :

$$
D_{i}=b+p\left(\frac{\frac{i . n}{10}-F}{f}\right) ; i=1,2, \ldots \ldots ., 9
$$

dengan :

$b$ = batas bawah kelas $D_{i}$, ialah kelas dimana $D_{i}$ akan terletak

$p=$ panjang kelas $D_{i}$

$F=$ jumlah frekuensi dengan tanda kelas lebih kecil dari tanda kelas $D_{i}$

$f=$ frekuensi kelas $D_{i}$

\section{Contoh 16}

Jika diminta $D_{3}$ untuk 80 nilai ujian statistika, maka kita perlu $30 \% \times 80=24$ data. Dapat dilihat bahwa kelas $D_{3}$ berimpit dengan kelas interval ke-4. Karenanya $b=60,5 ; p=10 ; f=15 ; F=1+2+5=8$. Dengan $i=3$ dan $n=$ 80 , maka dengan rumus di atas di dapat :

$$
D_{3}=60,5+(10)\left(\frac{\frac{3 \times 80}{10}-8}{15}\right)=71,2
$$

Artinya ada $70 \%$ mahasiswa paling sedikit mendapat nilai 71,2 dan $30 \%$ lagi mendapat nilai paling besar 71,2.

Berikut ini, akan dibahas tentang persentil. Sekumpulan data yang dibagi menjadi 100 bagian yang sama akan menghasilkan 99 pembagi yang berturutturut dinamakan persentil pertama, persentil kedua,..........persentil ke-99. Simbol yang digunakan berturut-turut adalah $\mathrm{P}_{1}, \mathrm{P}_{2}, \ldots \ldots . . \mathrm{P}_{99}$.

Karena cara perhitungannya sama seperti perhitungan desil maka disini hanya diberikan rumus-rumus letak persentil dan nilai persentil.

Letak persentil $P_{i}$ untuk sekumpulan data ditentukan oleh rumus :

$$
\text { Letak } P_{i}=\text { data } k e-\frac{i(n+1)}{100} ; i=1,2, \ldots, 99
$$

Sedangkan nilai $P_{i}$ untuk data dalam daftar distribusi frekuensi dihitung dengan rumus :

$$
P_{i}=b+p\left(\frac{\frac{i . n}{100}-F}{f}\right), i=1,2, \ldots, 99
$$

$b$ = batas bawah kelas $P_{i}$, ialah kelas dimana $P_{i}$ akan terletak

$p=$ panjang kelas $P_{i}$

$F=$ jumlah frekuensi dengan tanda kelas lebih kecil dari tanda kelas $P_{i}$

$f=$ frekuensi kelas $P_{i}$ 


\subsection{SOAL LATIHAN}

1. Di bawah ini adalah data dari nilai ujian Metode Statistika untuk sekelompok mahasiswa.

$65,64,69,76,75,71,72,70,75,78,65,78,56,69,68,76,80,57,66$

Hitunglah :

a. Nilai rata-rata dari ujian Metode Statistika untuk sekelompok mahasiswa diatas.

b. Median dari data diatas

c. Kuartil 3 dan kuartil 1 untuk nilai ujian diatas

d. Modus dari data diatas

2. Diketahui tabel distribusi frekuensi :

\begin{tabular}{|c|c|}
\hline Nilai & Frekuensi (fi) \\
\hline $31-35$ & 4 \\
$36-40$ & 3 \\
$41-45$ & 6 \\
$46-50$ & 7 \\
$51-55$ & 10 \\
$56-60$ & 13 \\
$61-65$ & 5 \\
\hline
\end{tabular}

Hitunglah nilai rata-rata untuk data dalam table di atas

3. Hitunglah $K_{1}$ dan $K_{3}$ dari data dalam nomor 2.

4. Hitunglah median dan modus untuk data dalam nomor 2.

5. Data daftar distribusi frekuensi tentang nilai ujian Metode Statistika untuk 60 mahasiswa :

\begin{tabular}{|c|c|}
\hline NILAI UJIAN & $f_{i}$ \\
\hline $31-40$ & 7 \\
$41-50$ & 3 \\
$51-60$ & 2 \\
$61-70$ & 1 \\
$71-80$ & 7 \\
$81-90$ & 10 \\
$91-100$ & 30 \\
\hline
\end{tabular}

Hitunglah rata-rata ukur dari nilai ujian Metode Statistika tersebut. 


\section{DAFTAR PUSTAKA}

Aczel, 1995, Statistical Conceps and applications.

Groeneveld, R., 1988, Introductory Statistical Methods, Iowa State University.

Murray R. Spegel, 1972, Statistics, New York, Mc Graw-Hill Book Co.

Sudjana, 2000, Metode Statistika, Penerbit Tarsito Bandung.

Supranto, 1986, Pengantar Probabilita dan Statistik Induktif, Jilid 2, Penerbit Erlangga.

Wibisono Y., 2005, Metode Statistik, Gadjah Mada University Press, Yogyakarta. 


\section{BAB IV UKURAN DISPERSI/PENYEBARAN}

\subsection{PENGANTAR}

Materi yang akan dibahas dalam bab ini adalah mengenai ukuran dispersi atau ukuran penyebaran yang meliputi materi mengenai Range, Deviasi Rata-rata/Simpangan Rata-rata, Variansi dan Standar Deviasi/Simpangan Baku, dan Ukuran Dispersi dengan Kuartil. Setelah mempelajari materi ini, Anda dapat menyelesaikan masalah mengenai ukuran dispersi, dan secara khusus dapat menjelaskan konsep mengenai Range, Deviasi Rata-rata/Simpangan Rata-rata, Variansi dan Standar Deviasi/Simpangan Baku, dan Ukuran Dispersi dengan Kuartil dalam hal ini Rentang Antar Kuartil dan Rentang Semi Kuartil. serta dapat menyelesaikan soal perhitungan dari setiap materi ukuran dispersi.

\subsection{URAIAN MATERI}

\section{A. Range/Rentang/Jangkauan}

Penentuan jarak sebuah distribusi merupakan pengukuran dispersi yang paling sederhana. Jarak sebuah distribusi frekuensi dirumuskan sebagai beda antara pengukuran nilai terbesar/maksimum $\left(\mathrm{X}_{\mathrm{A}}\right)$ dan nilai terkecil/minimum $\left(\mathrm{X}_{\mathrm{B}}\right)$ yang terdapat dalam sebuah distribusi. Jarak tersebut dinamakan range, dan secara matematis dirumuskan sebagai

$$
\mathrm{R}=\mathrm{X}_{\mathrm{A}}-\mathrm{X}_{\mathrm{B}}
$$

\section{Contoh 1}

Nilai mata kuliah Statistika Dasar 5 mahasiswa adalah sebagai berikut :

$$
\begin{array}{lllll}
30 & 90 & 50 & 70 & 60
\end{array}
$$

Maka Range dari data di atas adalah $\mathrm{R}=90-30=60$

\section{B. Deviasi Rata-rata/Simpangan Rata-rata}

Dispersi nilai-nilai observasi/pengamatan akan kecil bila nilai-nilai tersebut berada di sekitar rata-ratanya (mean). Sebaliknya, dispersi akan menjadi besar bila nilai-nilai observasi menyebar jauh dari rata-ratanya. Statistisi umumnya memberi perumusan tentang dispersi atas dasar jarak (deviasi) nilai-nilai observasi di atas nilai rata-ratanya.

Bila nilai-nilai observasi $X_{1}, X_{2}, \ldots, X_{n}$ memiliki rata-rata $\bar{X}$, maka deviasi nilai-nilai di atas dari rata-ratanya secara berturut-turut dapat dinyatakan sebagai $X_{1}-\bar{X}, X_{2}-\bar{X}, \ldots, X_{n}-\bar{X}$. Penjumlahan deviasi-deviasi di atas nilai rata-ratanya menjadi $\sum\left(X_{i}-X\right)$.

Tetapi jika kita berbicara tentang jarak atau rentang atau selisih, kita tidak boleh membedakan antara nilai yang bertanda negatif maupun positif. Oleh karena itu, nilai jarak tadi diambil harga mutlaknya. Deviasi rata-rata 
adalah rata-rata penyimpangan tiap data terhadap meannya. Deviasi ratarata dari seluruh nilai observasi $X_{i}$ adalah nilai mutlak besarnya perbedaan antara data dan meannya.

a. Data tidak dikelompokkan

Misalnya $X_{1}, X_{2}, \ldots, X_{n}$ adalah sekumpulan data dengan rata-rata (mean) $\bar{X}$, maka deviasi rata-rata dirumuskan sebagai

$$
d_{\bar{X}}=\frac{\sum_{i=1}^{n}\left|X_{i}-\bar{X}\right|}{n}
$$

\section{Contoh 2}

Data berikut adalah nilai ujian matematika dari 5 orang siswa :

$$
\begin{array}{lllll}
60 & 65 & 59 & 71 & 65
\end{array}
$$

Dari data tersebut, diperoleh meannya adalah $\bar{X}=64$

\begin{tabular}{|c|c|c|}
\hline \multicolumn{3}{|c|}{ Tabel 1} \\
\hline$X_{i}$ & $\bar{X}$ & $\left|X_{i}-\bar{X}\right|$ \\
\hline 60 & \multirow{5}{*}{64} & 4 \\
\hline 65 & & 1 \\
\hline 59 & & 5 \\
\hline 71 & & 7 \\
\hline 65 & & 1 \\
\hline $\mathrm{Ju}$ & ah & 18 \\
\hline
\end{tabular}

Maka deviasi rata-rata :

Jadi $d_{\bar{X}}=\frac{18}{5}=3,6$

b. Data dikelompokkan

Bila nilai-nilai observasi sudah dikelompokkan ke dalam bentuk distribusi frekwensi, maka deviasi rata-ratanya dapat dirumuskan sebagai

$$
d_{\bar{X}}=\frac{\sum_{i=1}^{k} f_{i}\left|X_{i}-\bar{X}\right|}{n}
$$

dimana

$\mathrm{X}_{\mathrm{i}}=$ titik tengah interval kelas ke-i (kelas frekwensi)

$\mathrm{f}_{\mathrm{i}}=$ frekwensi interval kelas ke-i

$\mathrm{n}=$ banyaknya data

$\mathrm{k}=$ banyaknya interval kelas 


\section{Contoh 3}

Dengan menggunakan data dalam Tabel 2, akan dihitung deviasi rata-rata data berkelompok

\begin{tabular}{|c|c|c|c|c|c|}
\hline Interval kelas & $X_{i}$ & $f_{i}$ & $\bar{X}$ & $\left|X_{i}-\bar{X}\right|$ & $\mathrm{f}_{\mathrm{i}}\left|X_{i}-\bar{X}\right|$ \\
\hline $165-167$ & 166 & 6 & & 8,64 & 51,84 \\
$168-170$ & 169 & 7 & & 5,64 & 39,48 \\
$171-173$ & 172 & 8 & & 2,64 & 21,12 \\
$174-176$ & 175 & 11 & 174,64 & 0,36 & 3,96 \\
$177-179$ & 178 & 7 & & 3,36 & 23,52 \\
$180-182$ & 181 & 6 & & 6,36 & 38,16 \\
$183-185$ & 184 & 5 & & 9,36 & 46,8 \\
\hline & & 50 & & & 224,88 \\
\hline
\end{tabular}

Deviasi rata-ratanya adalah :

$d_{\bar{X}}=\frac{224,88}{50}=4,4976$

\section{Variansi dan Standar Deviasi/Simpangan Baku}

Variansi sampel didefinisikan sebagai jumlah kuadrat deviasi terhadap rata-rata sampel dibagi $n-1$, yaitu:

a. Data tidak dikelompokkan

$$
S^{2}=\frac{1}{n-1} \sum_{i=1}^{n}\left(X_{i}-\bar{X}\right)^{2}=\frac{1}{n-1}\left[\sum_{i=1}^{n} X_{i}^{2}-\frac{1}{n}\left(\sum_{i=1}^{n} X_{i}\right)^{2}\right]
$$

Standar deviasi sampel didefinisikan sebagai akar positif dari variansi sampel yaitu :

$$
S=\sqrt{S^{2}}
$$

\section{Contoh 4}

\begin{tabular}{|c|c|c|}
\hline \multicolumn{3}{|c|}{ Tabel 3} \\
\hline$X_{i}$ & $\bar{X}$ & $\left(X_{i}-\bar{X}\right)^{2}$ \\
\hline 60 & \multirow{5}{*}{64} & 16 \\
\hline 65 & & 1 \\
\hline 59 & & 25 \\
\hline 71 & & 49 \\
\hline 65 & & 1 \\
\hline $\mathrm{Ju}$ & lah & 92 \\
\hline
\end{tabular}

Hitunglah variansi dan standar deviasi untuk data dalam Tabel 3 berikut :

Jadi variansinya adalah $S^{2}=\frac{1}{n-1} \sum_{i=1}^{n}\left(X_{i}-\bar{X}\right)^{2}=\frac{92}{4}=23$

dan standar deviasi atau simpangan baku adalah $S=\sqrt{23}=4,796$ 


\section{Contoh 5}

Hitunglah variansi dan standar deviasi untuk data berikut :

$\begin{array}{llllllllll}5,5 & 6,6 & 8,2 & 13,4 & 13,0 & 15,7 & 3,9 & 5,8 & 12,5 & 5,7\end{array}$

$\sum_{i=1}^{10} X_{i}=5,5+6,6+8,2+\ldots+5,7=90,3$

$\sum_{i=1}^{10} X_{i}^{2}=5,5^{2}+6,6^{2}+8,2^{2}+\ldots+5,7^{2}=973,69$

Sehingga variansinya adalah

$$
S^{2}=\frac{1}{10-1}\left[\sum_{i=1}^{10} X_{i}^{2}-\frac{1}{10}\left(\sum_{i=1}^{10} X_{i}\right)^{2}\right]=\frac{1}{9}\left[973,69-\frac{(90,3)^{2}}{10}\right]=17,587
$$

dan simpangan bakunya adalah $\mathrm{S}=\sqrt{17,587}=4,194$

b. Data dikelompokkan

$$
S^{2}=\frac{1}{n-1} \sum_{i=1}^{k} f_{i}\left(X_{i}-\bar{X}\right)^{2}=\frac{1}{n-1}\left[\sum_{i=1}^{k} f_{i} X_{i}^{2}-\frac{1}{n}\left(\sum_{i=1}^{k} f_{i} X_{i}\right)^{2}\right]
$$

Standar deviasi sampel didefinisikan sebagai akar positif dari variansi sampel yaitu :

$$
S=\sqrt{S^{2}}
$$

\section{Contoh 6}

Akan dihitung variansi dan standar deviasi untuk data usia 150 akseptor KB di suatu klinik sebagaimana terlihat dalam Tabel 4.

Tabel 4

\begin{tabular}{|c|c|c|r|c|r|}
\hline Usia akseptor & $X_{i}$ & $\bar{X}$ & $\left(X_{i}-\bar{X}\right)^{2}$ & $f_{i}$ & $f_{i}\left(X_{i}-\bar{X}\right)^{2}$ \\
\hline $15-19$ & 17 & & 172,3969 & 1 & 172,3969 \\
$20-24$ & 22 & & 66,0969 & 29 & $1.916,8101$ \\
$25-29$ & 27 & & 9,7969 & 43 & 421,2667 \\
$30-34$ & 32 & 30,13 & 3,4969 & 41 & 143,3729 \\
$35-39$ & 37 & & 47,1969 & 24 & $1.132,7256$ \\
$40-44$ & 42 & & 140,8969 & 12 & $1.690,7628$ \\
\hline & & & & 150 & $5.477,3350$ \\
\hline
\end{tabular}

Jadi variansinya adalah

$$
S^{2}=\frac{1}{n-1} \sum_{i=1}^{k} f_{i}\left(X_{i}-\bar{X}\right)^{2}=\frac{5,477,3350}{149}=36,7606
$$

dan standar deviasi atau simpangan baku adalah

$$
S=\sqrt{36,7606}=6,0631
$$




\section{Contoh 7}

Akan dihitung variansi dan standar deviasi untuk data dalam Tabel 5

Tabel 5

\begin{tabular}{|c|c|c|r|c|c|}
\hline Interval kelas & $X_{i}$ & $f_{i}$ & $f_{i} X_{i}$ & $X_{i}^{2}$ & $f_{i} X_{i}^{2}$ \\
\hline $165-167$ & 166 & 6 & 996 & 27556 & 165336 \\
$168-170$ & 169 & 7 & 1183 & 28561 & 199927 \\
$171-173$ & 172 & 8 & 1376 & 29584 & 236672 \\
$174-176$ & 175 & 11 & 1925 & 30625 & 336875 \\
$177-179$ & 178 & 7 & 1246 & 31684 & 221788 \\
$180-182$ & 181 & 6 & 1086 & 32761 & 196566 \\
$183-185$ & 184 & 5 & 920 & 33856 & 169280 \\
\hline Jumlah & & 50 & 8.732 & & 1.526 .444 \\
\hline
\end{tabular}

Variansinya adalah :

$$
S^{2}=\frac{1}{n-1}\left[\sum_{i=1}^{k} f_{i} X_{i}^{2}-\frac{1}{n}\left(\sum_{i=1}^{k} f_{i} X_{i}\right)^{2}\right]=\frac{1}{49}\left[1.526,444-\frac{(8.732)^{2}}{50}\right]=30,358
$$

Standar deviasinya adalah $\sqrt{30,358}=5,51$

\section{Ukuran Dispersi dengan Kuartil}

Sebagaimana diketahui bahwa dalam suatu kelompok data kuantitatif terdapat tiga nilai kuartil yaitu $\mathrm{K}_{1}, \mathrm{~K}_{2}$, dan $\mathrm{K}_{3}$. Selisih antara nilai kuartil tiga $\left(\mathrm{K}_{3}\right)$ dengan kuartil dua $\left(\mathrm{K}_{2}\right)$ disebut Rentang Antar Kuartil (RAK)/Sebaran tengah/sebaran antar kuartil/jarak antar kuartil. Secara umum dapat ditulis dalam bentuk formula :

$$
\mathrm{RAK}=\mathrm{K}_{3}-\mathrm{K}_{1}
$$

Selaian RAK ada dispersi lain yang dinamakan "Rentang Semi Kuartil" (RSK). Nilai RSK sama dengan setengah nilai RAK. Dengan singkat dapat ditulis dalam bentuk formula :

$$
\mathrm{RSK}=\frac{K_{3}-K_{1}}{2}
$$

\section{Contoh 8}

Hasil ujian statistika dari 50 mahasiswa menghasilkan nilai $\mathrm{K}_{3}=60,051$ dan $\mathrm{K}_{1}=45,895$. Sehingga :

$$
\begin{aligned}
& \mathrm{RAK}=\mathrm{K}_{3}-\mathrm{K}_{1}=60,051-45,895=14,156 \\
& \mathrm{RSK}=\frac{K_{3}-K_{1}}{2}=\frac{60,051-45,895}{2}=7,078
\end{aligned}
$$




\subsection{SOAL LATIHAN}

1. Berikut ini adalah data berat badan $(\mathrm{kg})$ dari calon mahasiswa yang akan masuk di suatu perguruan tinggi :

$\begin{array}{lllllllll}75 & 68 & 66 & 60 & 55 & 56 & 82 & 76 & 66\end{array}$

$\begin{array}{lllllllll}63 & 61 & 51 & 30 & 48 & 55 & 62 & 71 & 69\end{array}$

Dengan menggunakan data di atas, hitunglah :
a. Range
b. Simpangan rata-rata
c. Variansi
d. Simpangan baku
e. Rentang antar kuartil
f. Rentang semi kuartil

2. Hitung simpangan baku dari data Nilai Ujian Matrikulasi Universitas "X" pada Tabel berikut:

\begin{tabular}{|c|c|}
\hline Nilai & Jumlah Mahasiswa \\
\hline $60-62$ & 5 \\
$63-65$ & 18 \\
$66-68$ & 42 \\
$69-71$ & 27 \\
$72-74$ & 8 \\
\hline Jumlah & 100 \\
\hline
\end{tabular}

\section{DAFTAR PUSTAKA}

Dajan, A. 2000. Pengantar Metode Statistika, Jilid I. 2000. Pustaka LP3ES Indonesia. Jakarta.

Hakim, A. 2002. Statistik Induktif (untuk Ekonomi dan Bisnis). Ekonisia. Yogyakarta.

Kusnandar, D. 2004. Metode Statistika dan Aplikasinya dengan Minitab dan Excel. Madyan Press. Yogyakarta.

Saefuddin, A., dkk. 2009. Statistika Dasar. Grasindo. Jakarta. 


\section{BAB V \\ KONSEP PELUANG}

\subsection{PENGANTAR}

Materi yang akan dibahas dalam Bab $\mathrm{V}$ adalah konsep mengenai peluang yang meliputi materi tentang Eksperimen, Teknik Membilang, Peluang dan Peluang Bersyarat. Dengan mempelajari materi ini, Anda dapat menggunakan konsep permutasi, kombinasi dan peluang untuk menyelesaikan masalah dalam bidang matematika maupun bidang lain.

\subsection{URAIAN MATERI}

\section{A. Eksperimen/Percobaan}

Peluang merupakan bagian matematika yang membahas pengukuran, tingkat keyakinan orang akan muncul atau tidak munculnya suatu kejadian atau peristiwa. Oleh karena itu, untuk mendiskusikannya dimulai dengan suatu pengamatan. Proses pengamatan tersebut dinamakan suatu eksperimen/percobaan, atau eksperimen adalah proses yang menghasilkan hasil pengukuran, perhitungan atau pengamatan.

\section{Contoh 1}

1. Melempar sebuah mata uang $n$ kali

2. Melempar sebuah dadu $n$ kali

3. Mengambil kelereng dari sebuah kotak berisi 4 kelereng putih, 3 kelereng merah dan 3 kelereng hijau berurutan tanpa pengembalian atau dengan pengembalian

4. Mengukur tinggi seseorang

5. Mengamati indeks prestasi sekelompok mahasiswa di akhir suatu tahun ajaran.

6. Mengambil sampel random berukuran $n$ dari suatu populasi tertentu.

Eksperimen acak (random experiment) memiliki sifat-sifat sebagai berikut:

a. Hasil eksperimen tak dapat diduga sebelumnya dengan tingkat

keyakinan yang pasti

b. Semua hasil yang mungkin dapat diberikan

c. Eksperimen dapat dilakukan berulang-ulang dalam kondisi yang sama

Suatu percobaan akan menghasilkan suatu hasil (outcomes) atau titik sampel. Himpunan yang berisi semua hasil yang mungkin dari suatu percobaan dinamakan ruang sampel. Ruang sampel (sample space) dinotasikan dengan $\mathrm{S}$.

\section{Contoh 2}

1. Suatu percobaan melempar sebuah mata uang logam satu kali, maka ruang sampelnya adalah $S=\{A, G\}$

A menyatakan angka, dan $\mathrm{G}$ menyatakan gambar. 
2. Eksperimen melempar sebuah mata uang logam 2 kali maka ruang sampelnya $S=\{A A, A G, G A, G G\}$

3. Suatu percobaan mengambil satu buah kartu dari enam buah kartu yang diberi nomor 1 sampai dengan 6, dan diperhatikan nomor dari kartu yang terambil (Gambar 1), maka ruang sampelnya adalah $\mathrm{S}=\{1,2,3,4,5,6\}$

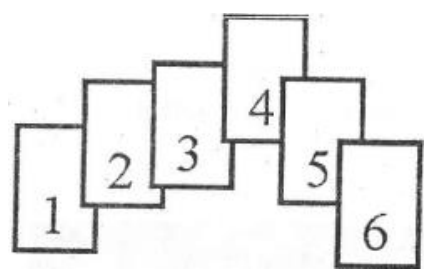

Gambar 1

Melanjutkan Contoh. 2 (3) di atas. Dalam pengambilan satu buah kartu dari enam buah kartu yang diberi nomor 1 sampai 6 , jika yang terambil adalah kartu dengan nomor genap maka hasil yang mungkin adalah kartu 2, 4, dan 6. Himpunan $\{2,4,6\}$ merupakan himpunan bagian dari ruang sampel $\{1,2,3,4,5,6\}$. Himpunan ini disebut kejadian dari suatu percobaan. Jadi, suatu kejadian atau peristiwa adalah himpunan bagian dari ruang sampel.

\section{Contoh 3}

1. Suatu percobaan dalam pelemparan sebuah mata uang logam sebanyak dua kali berurutan. Ruang sampel $S=\{A A, A G, G A$, GG). Kejadian munculnya paling sedikit satu sisi angka adalah \{AA, AG, GA $\}$.

2. Dari percobaan melempar satu buah mata dadu, maka ruang sampel $\mathrm{S}=\{1,2,3,4,5,6\}$

$\mathrm{A}=$ Kejadian munculnya mata dadu kurang dari $4 . \mathrm{A}=\{1,2,3\}$

$\mathrm{B}=$ Kejadian munculnya mata dadu 6. Maka $\mathrm{B}=\{6\}$

$\mathrm{C}=$ Kejadian munculnya mata dadu yang habis dibagi 3. $\mathrm{C}=\{3,6\}$.

\section{Contoh 4}

Sebuah mata uang yang seimbang dilemparkan sebanyak tiga kali

a. Tentukan ruang sampel dari eksperimen ini

b. Tulislah peristiwa-peristiwa berikut dalam bentuk himpunan

$A=$ peristiwa muncul 1 kali Angka

$B=$ peristiwa muncul 2 kali Angka

$C=$ peristiwa muncul paling banyak 1 kali Angka

Penyelesaian :

a. Ruang sampelnya adalah

$$
S=\{\text { AAA,GAA,GGA,AGG,AAG,AGA,GAG,GGG }\}
$$

b. $\mathrm{A}=\{\mathrm{GGA}, \mathrm{GAG}, \mathrm{AGG}\} ; \quad \mathrm{B}=\{\mathrm{AAG}, \mathrm{AGA}, \mathrm{GAA}\}$;

$$
\mathrm{C}=\{\mathrm{GGA}, \mathrm{GAG}, \mathrm{GGG}\}
$$




\section{Contoh 5}

Eksperimen dua buah dadu dilempar secara bersamaan

a. Tentukan ruang sampelnya

b. Tulis peristiwa di bawah ini dalam bentuk himpunan

$\mathrm{A}=$ Peristiwa jumlah nilai kedua dadu sama dengan 7

$\mathrm{B}=$ Peristiwa jumlah nilai kedua dadu lebih kecil atau kurang dari 5

$\mathrm{C}=$ Peristiwa beda nilai kedua dadu lebih besar sama dengan 4

Penyelesaian :

a. Ruang sampelnya,

$$
\begin{aligned}
S= & \{(1,1),(1,2),(1,3),(1,4),(1,5),(1,6),(2,1),(2,2),(2,3),(2,4),(2,5),(2,6), \\
& (3,1),(3,2),(3,3),(3,4),(3,5),(3,6),(4,1),(4,2),(4,3),(4,4),(4,5),(4,6), \\
& (5,1),(5,2),(5,3),(5,4),(5,5),(5,6),(6,1),(6,2),(6,3),(6,4),(6,5),(6,6)\}
\end{aligned}
$$

. Berdasarkan ruang sample $S$ di atas terlihat bahwa :

$$
\begin{aligned}
& A=\{(1,6),(2,5),(3,4),(4,3),(5,2),(6,1)\} \\
& B=\{(1,1),(1,2),(1,3),(2,1),(2,2),(3,1)\} \\
& C=\{(1,5),(1,6),(2,6),(5,1),(6,1),(6,2)\}
\end{aligned}
$$

Ruang nol atau ruang kosong ialah himpunan bagian ruang sampel yang tidak mengandung unsur. Himpunan seperti ini dinyatakan dengan lambang $\varnothing$.

\section{Contoh 6}

A adalah kejadian terambilnya kartu bernomor 7 dari percobaan pengambilan kartu yang diberi nomor 1 sampai 6. Dengan demikian, banyaknya hasil yang mungkin dari suatu kejadian adalah nol. maka $A=\varnothing$.

Hubungan antara kejadian dan ruang sampel padanannya dapat digambarkan dengan diagram venn. Dalam suatu diagram venn, ruang sampel dapat digambarkan dengan persegi panjang dan kejadian dinyatakan dengan lingkaran di dalamnya.

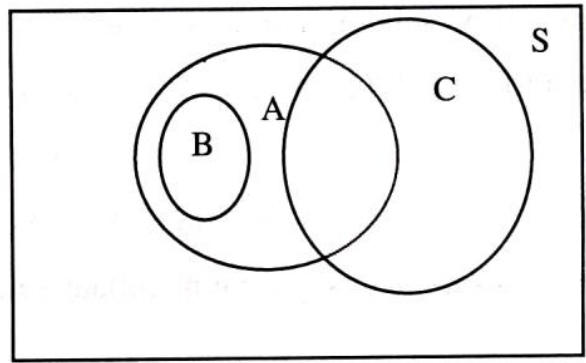

Gambar 2

Jadi kejadian A, B, dan C ketiganya merupakan himpunan bagian dari ruang sampel $S$. Juga jelas bahwa kejadian B adalah himpunan bagian kejadian A. Kejadian B dan C tidak mempunyai titik sampel yang 
sama; dan kejadian $\mathrm{A}$ dan $\mathrm{C}$ paling sedikit mempunyai titik sampel persekutuan.

Hasil yang diharapkan dari suatu percobaan tidak selalu merupakan kejadian tunggal. Dapat saja terjadi munculnya dua kejadian atau lebih. Kejadian yang terdiri dari 2 kejadian atau lebih disebut kejadian majemuk. Dalam kegiatan belajar ini akan didiskusikan kejadiankejadian majemuk.

Perhatikan masalah berikut.

1. Dari calon mahasiswa yang akan memasuki suatu perguruan tinggi diuji kemampuan bahasa Inggris dan matematikanya. Dari seluruh peserta $8 \%$ gagal tes bahasa Inggris, $12 \%$ gagal tes matematika, dan $4 \%$ gagal keduanya. Pimpinan perguruan tinggi tersebut ingin mengetahui berapa persen mahasiswa yang gagal tes bahasa Inggris atau matematika.

2. Satu buah kartu diambil dari seperangkat kartu bridge. Berapa peluang yang terambil adalah kartu As atau kartu keriting?

Kedua masalah di atas merupakan contoh dari kejadian majemuk, dimana kejadian pertama dapat terjadi bersamaan dengan kejadian kedua. Dalam contoh pertama, gagal tes kedua-duanya dapat terjadi bersamaan, yaitu seorang mahasiswa bisa gagal tes bahasa Inggris sekaligus gagal tes matematika. Dalam contoh kedua, dapat terjadi kartu yang terambil adalah kartu As dengan gambar keriting.

\section{Hubungan Antar Peristiwa}

1. Irisan/Interseksi

Interseksi 2 peristiwa A dan B adalah suatu peristiwa yang hasilhasilnya merupakan hasil dalam A yang sekaligus merupakan hasil dalam B. Atau hasil dalam B yang sekaligus adalah hasil dalam A. A iris B biasa ditulis sebagai $A \cap B$.

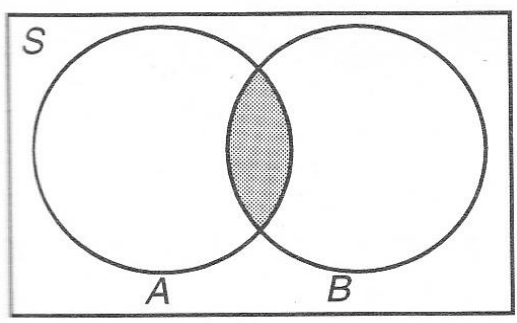

$A \cap B$

Gambar 3

2. Gabungan (Union)

Gabungan 2 peristiwa A dan B adalah suatu peristiwa yang hasilhasilnya merupakan hasil dalam A atau hasil dalam B. Artinya kejadian yang mengandung semua unsur yang termasuk di A atau di B atau keduanya. 


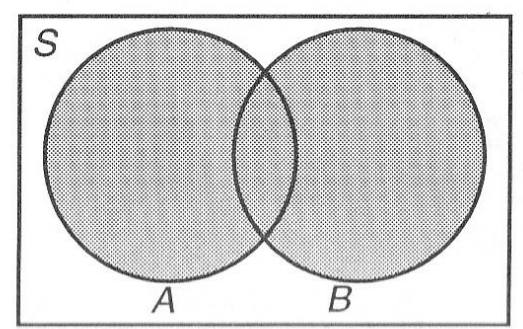

$A \cup B$

Gambar 4

3. Komplemen

Komplemen peristiwa $\mathrm{A}$ adalah suatu peristiwa dalam $\mathrm{S}$ yang hasilhasilnya bukan merupakan hasil dari A. Komplemen dari peristiwa A ditulis sebagai $A^{C}$.

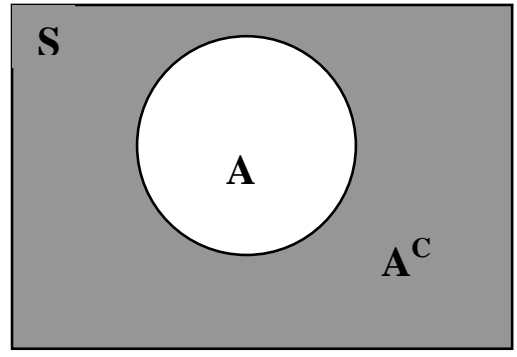

Gambar 5

\section{Contoh 7}

Perhatikan suatu ruang sampel dari hasil pelemparan sebuah dadu. $\mathrm{S}=\{1,2,3,4,5,6\}$. Kejadian-kejadian berikut adalah kejadian-kejadian dalam ruang sampel $\mathrm{S}$.

$A=$ munculnya sisi ganjil $=\{1,3,5\}$;

$\mathrm{B}=$ munculnya sisi genap $=\{2,4,6\} ; \quad \mathrm{C}=\{1,2,3,4,5\}$;

$\mathrm{D}=\{4,5,6\} ; \quad \mathrm{E}=\{1,2\} ; \quad \mathrm{F}=\{3,4\}$

1. $\mathrm{A} \cup \mathrm{B}=\mathrm{S}$

2. $\mathrm{A} \cap \mathrm{B}=\varnothing$

3. $\mathrm{B} \cup \mathrm{C}=\mathrm{S}$

4. $\mathrm{B} \cap \mathrm{C}=\{2,4\}$

5. $(\mathrm{B} \cap \mathrm{C}) \cap \mathrm{F}=\{4\}$

6. $(B \cap C) \cup F=\{2,3,4\}$

7. $\mathrm{D} \cup \mathrm{E}=\{1,2,4,5,6\}$

8. $\mathrm{F}^{\mathrm{C}}=\{1,2,5,6\}$

9. $(\mathrm{D} \cup \mathrm{E})^{\mathrm{C}}=\{3\}$

10. $\left(A \cup C^{C}\right)=\{1,3,5,6\}$

\section{B. Teknik Membilang/menghitung}

Kebanyakan persoalan dalam peluang membutuhkan perhitungan khusus. Sering kali kita mendaftar tentang banyaknya hasil yang mungkin terjadi yakni anggota-anggota dari ruang sampel, namun apabila hasil yang mungkin tersebut cukup banyak, maka diperlukan 
aturan khusus untuk mengetahui banyaknya anggota di dalam suatu ruang sampel.

\section{Contoh 8}

Pada lomba lari cepat 100 meter, empat orang lolos ke putaran akhir, yaitu Adri (A), Firdaus (F), Ilham (I), dan Wahyu (W). Pada pertandingan itu tersedia dua hadiah. Berapa macam susunan pemenang yang mungkin muncul pada akhir pertandingan?

Penyelesaian :

Pada putaran akhir pertandingan ada 4 kemungkinan pengisian pemenang pertama, yaitu A, F, I atau W. Setelah salah satu dari mereka ini mencapai garis akhir, pelari berikutnya adalah salah satu dari tiga pelari yang tidak berhasil menjadi juara pertama. Apa saja susunan pemenang pertama dan kedua yang mungkin, untuk lebih jelasnya dapat disusun dalam diagram pohon.

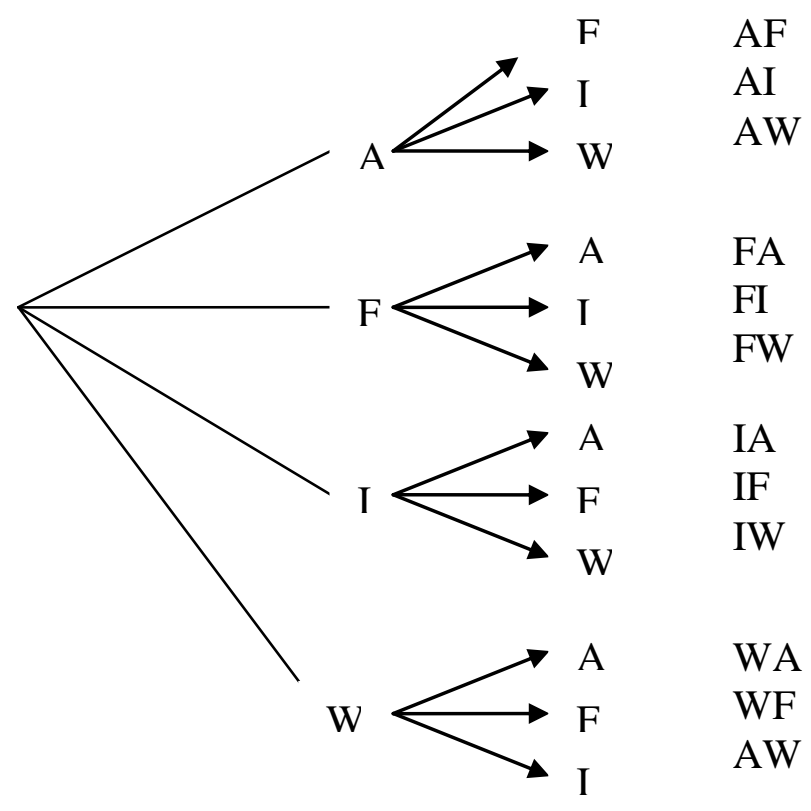

\section{Gambar 6}

Dari diagram pohon di atas dapat ditemukan hasil: $4 \times(4-1)=12$ susunan pemenang yang mungkin, yaitu AF, AI, AW, FA, FI, FW, IA, IF, IW, WA, WF. WI). Huruf pertama adalah peserta yang menempati juara pertama dan huruf kedua adalah peserta yang menempati juara kedua.

\section{Contoh 9}

Kita akan mengadakan perjalanan dari Jakarta ke Bandung, lalu ke Yogyakarta, Solo, dan terakhir ke Malang. Dari Jakarta ke Bandung ada 2 macam kendaraan yang dapat kita gunakan, yaitu bus (B) atau kereta api (K). Dari Bandung ke Yogyakarta ada 3 macam kendaraan yang dapat kita gunakan, yaitu bus (B), kereta api $(\mathrm{K})$, atau pesawat $(\mathrm{P})$, sedangkan dari Yogyakarta ke Malang ada 2 macam kendaraan yang 
dapat kita gunakan, yaitu bus (B) atau taxi (T). Kita harus memutuskan kendaraan mana yang dapat kita gunakan untuk tiap-tiap perjalanan. Diagram pohon berikut menunjukkan pilihan kita untuk melakukan perjalanan tersebut.

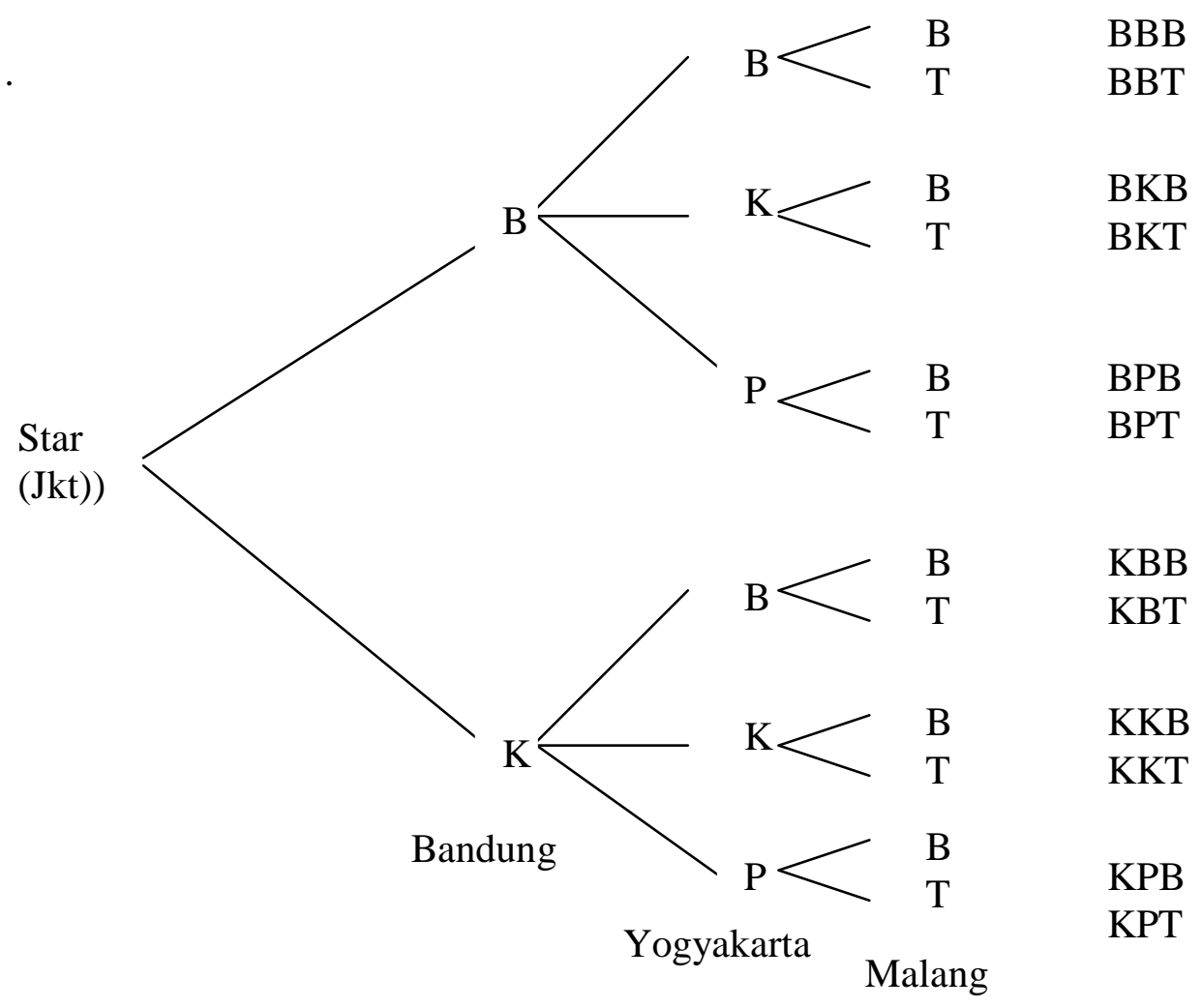

\section{Gambar 7}

Perjalanan pertama dapat menggunakan 2 cara, perjalanan kedua dengan 3 cara, dan perjalanan ketiga dengan 2 cara. Perhatikan bahwa banyaknya cara perjalanan yang dapat dipilih adalah: $2 \times 3 \times 2=12$ cara.

\section{Contoh 10}

Pada suatu universitas diberlakukan aturan bahwa tiap mahasiswa baru harus mengambil mata kuliah fisika, kimia dan matematika. Bila seorang mahasiswa dapat memilih satu dari tiga mata kuliah fisika, satu dari empat mata kuliah kimia dan satu dari dua mata kuliah matematika. Berapa banyak cara mahasiswa baru tersebut dapat menyusun programnya?

Penyelesaian :

Mahasiswa baru dapat menyusun programnya sebanyak :

$$
(3)(4)(2)=24
$$


Contoh-contoh yang diberikan, mengarah pada suatu prinsip yang disebut prinsip dasar menghitung, yaitu berikut ini:

1. Jika dua percobaan yang dilakukan secara berurutan dengan $\mathrm{n}_{1}$ hasil yang mungkin dari percobaan pertama dan $\mathrm{n}_{2}$ hasil yang mungkin dari percobaan kedua, maka ada $\mathrm{n}_{1} \mathrm{x}_{2}$ kombinasi hasil dari percobaan pertama dan kedua.

2. Jadi jika k percobaan dilakukan berurutan, dengan banyaknya hasil yang mungkin dari tiap-tiap percobaan berturut-turut adalah $\mathrm{n}_{1}, \mathrm{n}_{2}$,

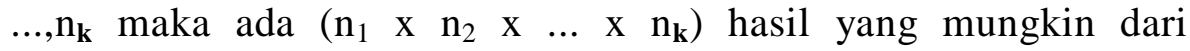
percobaan-percobaan yang dilakukan tersebut.

\section{a. Permutasi}

Misalnya, dari empat huruf dalam $\{\mathrm{A}, \mathrm{B}, \mathrm{C}, \mathrm{D}\}$ akan dibentuk pasangan berurut yang terdiri dari dua huruf yang berbeda. Himpunan pasangan berurut yang diperoleh adalah $\{(\mathrm{A}, \mathrm{B}),(\mathrm{A}, \mathrm{C})$, $(\mathrm{A}, \mathrm{D}),(\mathrm{B}, \mathrm{A}),(\mathrm{B}, \mathrm{C}),(\mathrm{B}, \mathrm{D}),(\mathrm{C}, \mathrm{A}),(\mathrm{C}, \mathrm{B}),(\mathrm{C}, \mathrm{D}),(\mathrm{D}, \mathrm{A}),(\mathrm{D}, \mathrm{B})$, $(\mathrm{D}, \mathrm{C})\}$. Perhatikan bahwa pasangan berurut $(\mathrm{A}, \mathrm{B})$ berbeda dengan (B, A). Demikian juga (B, D) berbeda dengan (D, B). Dalam pasangan berurut ini urutan diperhatikan. Jika suatu susunan memperhatikan urutan, maka susunan itu disebut permutasi. Contoh di atas merupakan permutasi 2 obyek dari 4 obyek, ditulis $P_{2}^{4}$.

Misalkan kita mempunyai $n$ obyek yang berbeda dan ingin menyusun $r$ obyek dari $n$ obyek tersebut. Maka banyaknya susunan yang mungkin adalah:

$$
P_{r}^{n}=\frac{n !}{(n-r) !} \quad \text { Jika } n=r \text { maka } P_{r}^{n}=n !
$$

Jika obyek-obyek tersebut berlainan. Misalkan suatu himpunan memuat $n$ obyek yang terdiri dari $n_{1}$ buah jenis pertama, $n_{2}$ buah jenis kedua, $\ldots, n_{k}$ buah jenis ke $k$ dimana $n=n_{1}+n_{2}+\ldots+n_{k}$ maka banyaknya permutasi yang berlainan dari $n$ obyek tersebut adalah:

$$
P_{n_{1}, n_{2}, \ldots, n_{k}}^{n}=\frac{n !}{n_{1} ! n_{2} ! . . n_{k} !}
$$

Bagaimana permutasi yang terdiri dari $n$ obyek dengan beberapa obyek yang sama? Secara umum dapat dibentuk suatu aturan untuk menentukan banyaknya permutasi dari n obyek dengan ada obyek yang sama. Misalnya, di dalam suatu himpunan terdapat $\mathrm{n}$ obyek yang terdiri dari:

$\mathrm{n}_{1}$ obyek pertama, $\mathrm{n}_{2}$ unsur kedua, ..., $\mathrm{n}_{\mathrm{k}}$ unsur ke-k. Maka banyaknya permutasi yang mungkin dari $\mathrm{n}$ unsur tersebut adalah sama dengan persamaan (2).

\section{Contoh 11}

Hitunglah :

a. Susunan dari 5 buah buku yang berbeda

b. Susunan dari 3 buah buku yang diambil dari 6 buah buku yang berbeda 
c. Permutasi yang berlainan dari 4 buku matematika, 2 buku kimia dan 3 buku fisika, jika buku-buku dalam setiap jenis sama.

Penyelesaian:

a. $P_{5}^{5}=5 !=120$

b. $P_{3}^{6}=\frac{6 !}{(6-3) !}=\frac{6 !}{3 !}=120$

c. $P_{M K, F}^{9}=\frac{9 !}{4 ! 2 ! 3 !}=1260$

\section{Contoh 12}

Dari 7 orang mahasiswa dipilih untuk menduduki jabatan sebagai ketua, wakil ketua, sekretaris, dan bendahara Badan Eksekutif Mahasiswa (BEM). Ada berapa cara pemilihan dapat dibentuk?

Penyelesaian :

Susunan jabatan adalah ketua, wakil ketua, sekretaris, dan bendahara, maka jika diperoleh susunan:

Ketua : Lelan

Wakil ketua : Bachri

Sekretaris : Riri

Bendahara : Saiful

akan berbeda dengan susunan:

Ketua : Bachri

Wakil ketua : Saiful

Sekretaris : Lelan

Bendahara : Riri

Jadi masalah ini adalah masalah permutasi, karena urutan diperhatikan. Sehingga permutasi 4 obyek dari 7 obyek adalah $P_{4}^{7}=\frac{7 !}{(7-4) !}=\frac{7 !}{3 !}=\frac{7 \times 6 \times 5 \times 4 \times 3 \times 2 \times 1}{3 \times 2 \times 1}=840$

Jadi banyaknyn cara pemilihan untuk menempati posisi jabatan tersebut adalah 840 cara.

\section{Contoh 13}

Berapa kata yang terdiri dari empat huruf dapat disusun dengan semua huruf pada kata "DADU"? Banyak huruf pada kata "DADU" ada 4 buah.

Penyelesaian :

Huruf D sebanyak 2 buah, huruf A sebanyak 1 buah, huruf $U$ sebanyak 1 buah. Maka $P_{2,1,1}^{4}=\frac{4 !}{2 ! 1 ! 1 !}=12$ kata. 


\section{b. Kombinasi}

Pada permutasi, unsur-unsur disusun dengan memperhatikan urutan. Bahasan berikutnya adalah susunan unsur-unsur dengan tidak memperhatikan urutan yang disebut dengan kombinasi. Misalnya, himpunan yang terdiri dari huruf $\{A, B, C, D\}$ akan dibentuk himpunan bagian yang terdiri dari 2 nnggota. Himpunan bagian yang diperoleh adalah $\{\mathrm{A}, \mathrm{B}\},\{\mathrm{A}, \mathrm{C}\},\{\mathrm{A}, \mathrm{D}\},\{\mathrm{B}, \mathrm{C}\}$, $\{B, D\},\{C, D\}$. Himpunan bagian ini merupakan salah satu contoh kombinasi, yaitu kombinasi 2 obyek dari 4 obyek, ditulis ${ }_{4} \mathrm{~K}_{2}$.

Pada kombinasi, susunan yang terdiri atas unsur yang sama walaupun urutannya tidak sama, hanya diperhitungkan satu kombinasi. Maka, $\{\mathrm{A}, \mathrm{B}\}=\{\mathrm{B}, \mathrm{A}\},\{\mathrm{A}, \mathrm{C}\}=\{\mathrm{C}, \mathrm{A}\},\{\mathrm{A}, \mathrm{D}\}=\{\mathrm{D}$, $A),\{B, C)=\{C, B),\{B, D\}=\{D, B\}$, dan $\{C, D\}=\{D, C\}$.

Banyaknya kombinasi $r$ obyek yang dipilih dari $n$ obyek dinyatakan sebagai:

$$
\left(\begin{array}{l}
n \\
r
\end{array}\right)=C_{r}^{n}=\frac{n !}{r !(n-r) !}
$$

\section{Peluang}

Misalnya, S mewakili suatu ruang sampel dengan $\mathrm{n}(\mathrm{S})$ banyaknya hasil yang mungkin yang mempunyai kesempatan sama untuk muncul (equally likely), dan misal A suatu kejadian pada ruang sampel S yang berisi $\mathrm{n}(\mathrm{A})$ atau hasilnya $\mathrm{A} \subseteq \mathrm{S}$. Maka peluang kejadian A didefinisikan dengan: $P(A)=\frac{n(A)}{n(S)}$.

Definisi tersebut menggunakan definisi peluang kiasik. Mengingat $\mathrm{A} \subseteq \mathrm{S}$ dan $\varnothing \subseteq \mathrm{A} \subseteq \mathrm{S}$ maka dapat ditulis: $\varnothing \subseteq \mathrm{A} \subseteq \mathrm{S}$

Jika $\mathrm{n}(\varnothing)=$ banyaknya hasil dari kejadian yang mustahil $=0$

$\mathrm{n}(\mathrm{A})=$ banyaknya hasil dari kejadian $\mathrm{A}$

$\mathrm{n}(\mathrm{S})=$ banyaknya hasil dari ruang sampel

maka: $\mathrm{n}(\varnothing) \leq \mathrm{n}(\mathrm{A}) \leq \mathrm{n}(\mathrm{S})$

$$
\begin{aligned}
0 & \leq \mathrm{n}(\mathrm{A}) \leq \mathrm{n}(\mathrm{S}) \\
0 & \leq \frac{n(A)}{n(S)} \leq 1 \\
& \frac{n(A)}{n(S)}=\mathrm{P}(\mathrm{A}), \text { maka } 0 \leq \mathrm{P}(\mathrm{A}) \leq 1 .
\end{aligned}
$$

\section{SIFAT-SIFAT PELUANG}

Misal, S suatu ruang sampel dan A suatu kejadian pada ruang sampel S.

1. Jika $\mathrm{A}=0$ maka $\mathrm{p}(\mathrm{A})=0$

2. Nilai peluang kejadian $\mathrm{A}$, yaitu $\mathrm{p}(\mathrm{A})$ berkisar dari 0 sampai 1 (0 p(A) 1).

3. Jumlah nilai peluang semua hasil dari suatu percobaan sama dengan 1 $(\mathrm{p}(\mathrm{S})=1)$. 


\section{Contoh 14}

Delapan bola yang diberi nomor 1 sampai 8 ditempatkan dalam. Suatu percobaan mengambil satu buah bola dari kotak tersebut. Tentukan:

a. ruang sampelnya.

b. Peluang kejadian

i) terambilnya bola bernomor 6

ii) terambilnya bola bernomor bilangan prima

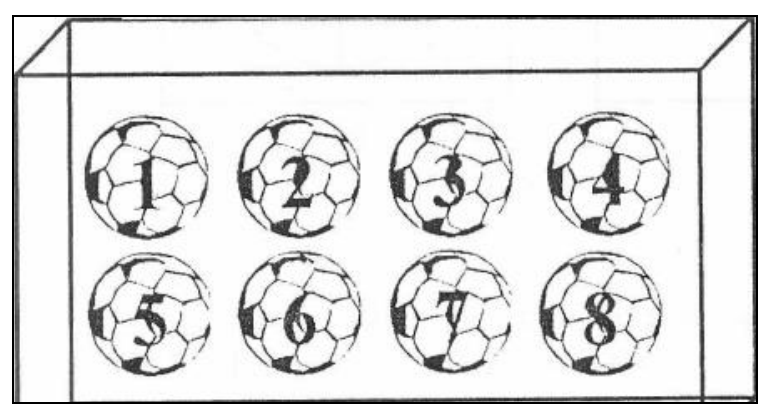

\section{Gambar 8}

Penyelesaian :

a. $\quad$ Ruang sampel $S=\{1,2,3,4,5,6,7,8\}$

b. Misal $\mathrm{A}=$ kejadian terambilnya bola bernomor 6 $\mathrm{B}=$ kejadian terambilnya bola bernomor bilangan prima $\mathrm{n}(\mathrm{A})=$ banyaknya hasil yang mungkin dari kejadian $\mathrm{A}$ $\mathrm{n}(\mathrm{B})=$ banyaknya hasil yang mungkin dari kejadian $\mathrm{B}$ diperoleh : $\mathrm{A}=\{6\} ; \mathrm{B}=\{2,3,5,7\}$

$$
\mathrm{n}(\mathrm{S})=8 \quad \mathrm{n}(\mathrm{A})=1 \quad \mathrm{n}(\mathrm{B})=4
$$

$$
\begin{aligned}
\text { Jadi : i) } \mathrm{P}(\mathrm{A}) & =\frac{n(A)}{n(S)}=\frac{1}{8} \\
\text { ii) } \mathrm{P}(\mathrm{B}) & =\frac{n(B)}{n(S)}=\frac{4}{8}=\frac{1}{2}
\end{aligned}
$$

\section{Contoh 15}

Sebuah kartu diambil dari satu set kartu bridge ( 52 kartu) dengan empat rnacam kartu, yaitu bergambar hati dan wajik berwarna merah, sedangkan sekop dan keriting berwarna hitam. Berapa peluang yang terambil adalah :
a. Kartu As
b. Kartu keriting

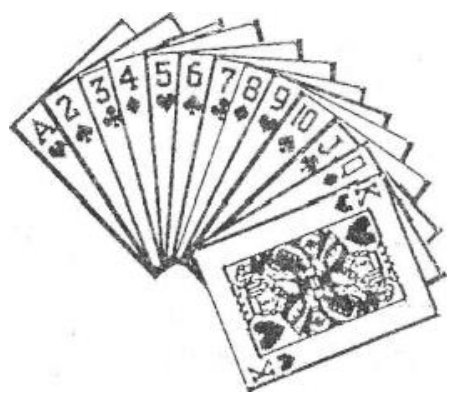

Gambar 9 
Penyelesaian :

Karena ada 52 kartu , maka $n(S)=52$

Dari seperangkat kartu bridge, hanya ada 4 kartu As, maka $n(A s)=4$ dan ada 13 kartu keriting, maka $\mathrm{n}($ Ker $)=13$

Jadi a). $\mathrm{P}(\mathrm{As})=\frac{n(A s)}{n(S)}=\frac{4}{52}=\frac{1}{13} \quad$ b). $\mathrm{P}($ Ker $)=\frac{n(\text { Ker })}{n(S)}=\frac{13}{52}=\frac{1}{4}$

\section{Peluang Bersyarat}

Ketika kita menentukan peluang terjadinya suatu kejadian A pada suatu keadaan dimana kejadian B telah terjadi, maka peluang yang demikian disebut peluang bersyarat (conditional probability), dan dinyatakan dengan notasi $\mathrm{P}(\mathrm{A} \mid \mathrm{B})$. Dalam menentukan $\mathrm{P}(\mathrm{A} \mid \mathrm{B})$, kita membatasi ruang lingkup perhatian kita hanya pada bagian percobaan yang menghasilkan kejadian B. Dengan demikian, peluang bersyarat $\mathrm{P}(\mathrm{A} \mid \mathrm{B})$ pada dasarnya mengukur bagian/pecahan dari kejadian $\mathrm{B}$ yang juga menghasilkan kejadian A. Peluang terjadinya kejadian A dengan syarat bahwa kejadian $\mathrm{B}$ telah terjadi dihitung dengan rumus:

$$
P(A \mid B)=\frac{P(A \cap B)}{P(B)}
$$

Dari definisi peluang bersyarat di atas maka dirumuskan bahwa jika A dan B dua peristiwa yang dapat terjadi pada suatu eksperimen acak, maka :

$$
P(A \cap B)=P(A) P(B \mid A)
$$

atau

$$
P(A \cap B)=P(B) P(A \mid B)
$$

\section{Contoh 16}

Misalnya dalam pengambilan sebuah kartu bridge, diketahui bahwa kartu yang terambil adalah kartu yang berwarna hitam, berapakah peluang terambilnya kartu As?

Penyelesaian :

Dalam hal ini, informasi yang diketahui adalah terpilihnya kartu warna hitam. Dalam satu set kartu bridge terdapat 26 kartu warna hitam (13 kartu - dan 13 kartu s) dan dua di antaranya adalah kartu As. Oleh karena itu, peluang terpilihnya kartu As jika diketahui bahwa kartu yang terpilih tersebut berwarna hitam adalah :

$\mathrm{P}($ As $\mid$ kartu hitam $)=\frac{\text { jumlah kartu As hitam }}{\text { jumlahkartu berwarnahitam. }}=\frac{2}{26}$

$P(A \mid B)=\frac{P(A \cap B)}{P(B)}=\frac{2 / 52}{26 / 52}=\frac{2}{26}$

Nilai peluang tersebut dapat juga dihitung dengan aturan (3). Misalnya kejadian A adalah terpilihnya kartu As, dan B adalah terpilihnya kartu 
berwarna hitam. Maka $\mathrm{P}(\mathrm{A} \cap \mathrm{B})=\mathrm{P}($ As berwarna hitam $)=2 / 52$, dan $\mathrm{P}(\mathrm{B})=\mathrm{P}($ kartu berwarna hitam $)=26 / 52$,

maka $\mathrm{P}(\mathrm{A} \mid \mathrm{B})=P(A \mid B)=\frac{P(A \cap B)}{P(B)}=\frac{2 / 52}{26 / 52}=\frac{2}{26}$

\section{Contoh 17}

Misalkan di suatu daerah terdapat 1000 Pasangan Usia Subur (PUS), dan mereka terbagi dalam klasifikasi berikut :

\begin{tabular}{|l|c|c|c|c|c|}
\hline \multirow{2}{*}{ KB } & \multicolumn{4}{|c|}{ Tingkat Pendidikan } & \multirow{2}{*}{ Jumlah } \\
\cline { 2 - 5 } & SD & SMTP & SMTA & PT & \\
\hline Ya & 150 & 200 & 300 & 50 & 700 \\
\hline Tidak & 100 & 100 & 75 & 25 & 300 \\
\hline Jumlah & 250 & 300 & 375 & 75 & 1000 \\
\hline
\end{tabular}

Jika diambil 1 PUS secara acak dari 1000 PUS di atas, hitunglah ;

a). Peluang terambil PUS yang berpendidikan SMTA

b). Peluang terambil PUS yang berpendidikan SMTP dan peserta KB

c). Peluang terambil PUS yang tidak ikut KB, jika PUS tersebut berpendidikan SD

d). Peluang terambil PUS yang berpendidikan PT, jika PUS tersebut peserta KB

Penyelesaian :

Misalkan $A_{1}, A_{2}, A_{3}, A_{4}$ adalah peristwa-peristiwa terambil PUS yang berpendidikan berturut-turut ; SD, SMTP, SMTA, dan PT. Kita tuliskan pula $B$ peristiwa terambil PUS peserta KB.

Di sini ruang sampel $S$ adalah himpunan ke 1000 PUS tersebut. Jelas $S$ uniform sebab pengambilan dilakukan secara acak. Dengan demikian maka:

a. $\quad P\left(A_{3}\right)=\frac{n\left(A_{3}\right)}{n(S)}=\frac{375}{1000}=0,375$

b. $\quad P\left(A_{2} \cap B\right)=\frac{n\left(A_{2} \cap B\right)}{n(S)}=\frac{200}{1000}=0,2$

c. yang ditanyakan di sini adalah $P\left(B^{C}\right.$ jika diketahui $A_{1}$ telah terjadi $)$.

Peluang ini diberi lambang $P\left(B^{c} \mid A_{1}\right)$ dan dibaca ; "Peluang dari $B^{c}$ jika

$A_{1}$ ". Berdasarkan Tabel di atas, kita peroleh :

$$
P\left(B^{C} \mid A_{1}\right)=\frac{n\left(B^{C} \cap A_{1}\right)}{n(S)}=\frac{100}{250}
$$

d. Yang ditanyakan adalah $P\left(A_{4}\right.$ jika diketahui $B$ telah terjadi $)$

$$
P\left(A_{4} \mid B\right)=\frac{n\left(A_{4} \mid B\right)}{n(B)}=\frac{50}{700}
$$

Perhatikan bahwa contoh di atas menunjukkan 


$$
\begin{aligned}
& P\left(B^{C} \mid A_{1}\right)=\frac{n\left(B^{C} \cap A_{1}\right)}{n\left(A_{1}\right)} \\
& P\left(A_{4} \mid B\right)=\frac{n\left(A_{4} \cap B\right)}{n(B)} \\
& \text { akan tetapi } \\
& \frac{n\left(B^{C} \cap A_{1}\right)}{n\left(A_{1}\right)}=\frac{n\left(B^{C} \cap A_{1}\right) / n(S)}{n\left(A_{1}\right) / n(S)}=\frac{P\left(B^{C} \cap A_{1}\right)}{P\left(A_{1}\right)} \\
& \frac{n\left(A_{4} \mid B\right)}{n(B)}=\frac{n\left(A_{4} \mid B\right) / n(S)}{n(B) / n(S)}=\frac{P\left(A_{4} \mid B\right)}{P(B)} \\
& \text { dengan demikian dapat ditulis : } \\
& \qquad P\left(B^{C} \mid A_{1}\right)=\frac{P\left(B^{C} \cap A_{1}\right)}{P\left(A_{1}\right)} \\
& \quad P\left(A_{4} \mid B\right)=\frac{P\left(A_{4} \mid B\right)}{P(B)}
\end{aligned}
$$

\section{3. SOAL LATIHAN}

1. Untuk mengecat pesawat terbang tersedia 5 macam warna cat, sedangkan ketentuan untuk mengecat pesawat terbang adalah warna sayap, body, dan ekornya harus berlainan. Ada berapa macam cara untuk mengecat pesawat terbang tersebut?

2. Suatu kotak berisi 5 bola merah dan 7 bola putih. Satu bola diambil dan dicatat warnanya, tetapi bola tidak dikembalikan lagi ke dalam kotak. Kemudian, diambil lagi satu buah bola dan dicatat warnanya. Berapa peluang bola yang terambil adalah bola warna merah diikuti bola putih?

3. Sebuah kartu diambil dari seperangkat kartu bridge yang telah dikocok. Kemudian, kartu tersebut dikembalikan dan kartu dikocok kembali. Satu buah kartu diambil lagi dari kocokan kedua. Berapa peluang diperoleh kartu As pada pengambilan pertama dan kartu King pada pengambilan kedua?

4. Suatu Sekolah Dasar (SD) masih mempunyai 6 orang guru yang belum memiliki ijazah S1. Pada tahun ajaran 2007/2008 sekolah tersebut mendapat kesempatan untuk gurunya mengikuti Program S1 PGSD di Universitas Terbuka sebanyak 4 orang. Berapakah banyaknya cara pimpinan sekolah itu memilih 4 orang dari 6 orang yang ada?

5. Dibentuk bilangan yang terdiri dari 3 angka berbeda yang disusun dari bilangan 1, 2, 3, 4, dan 5. Berapa peluang bilangan yang terbentuk lebih besar dari 500 ?

6. Sebuah kotak berisi empat buah bola yang diberi nomor 1 sampai 4. Satu buah bola diambil dari kotak dan dicatat nomornya, lalu bola tersebut dikembalikan ke dalam kotak. Kemudian, bola kedua diambil dan dicatat nomornya. Tentukan:

a. semua basil yang mungkin-dari pengambilan dua bola tersebut.

b. peluang jumlah angka dari kedua bola yang terambil kurang dari

7. Percobaan dan pertanyaan sama dengan soal nomor 6 tetapi bola pertama 
tidak dikembalikan ke dalam kotak.

8. Data yang dimiliki oleh badan koordinasi penanaman modal (BKPM) mengenai asal investasi dan bidang investasi pada suatu periode tertentu tercatat sebagai berikut :

\begin{tabular}{|c|c|c|c|}
\hline \multirow{2}{*}{$\begin{array}{c}\text { Asal } \\
\text { Investasi }\end{array}$} & \multicolumn{2}{|c|}{ Bidang Investasi } & \multirow{2}{*}{ Jumlah } \\
\cline { 2 - 3 } & Sektor Investasi & Sektor-Non Investasi & \\
\hline PMDN & 110 & 10 & 120 \\
\hline PMA & 50 & 30 & 80 \\
\hline Jumlah & 160 & 40 & 200 \\
\hline
\end{tabular}

PMDN : Penanaman Modal Dalam Negeri

PMA : Penanaman Modal Asing

Jika tersiar kabar bahwa salah seorang inverstor akan memperbesar investasinya. Berapa peluang bahwa investor tersebut adalah :

a. seorang investor asing yang menanam modalnya di sektor non industri

b. seorang investor asing atau seorang investor yang menanam modalnya di sektor non industri

9. Di Perguruan Tinggi A, $25 \%$ mahasiswanya gagal dalam ujian matematika, $15 \%$ gagal dalam ujian statistika, dan $10 \%$ gagal dalam keduanya. Seorang mahasiswa dipanggil secara acak

a. Berapa peluangnya bahwa ia gagal dalam matematika atau statistika

b. Jika ia gagal dalam matematika, berapa peluangnya gagal dalam statistika

c. Jika ia gagal dalam statistika, berapa peluangnya ia gagal di matematika

\section{DAFTAR PUSTAKA}

Hakim, A. 2002. Statistik Induktif (untuk Ekonomi dan Bisnis). Ekonisia. Yogyakarta.

Kusnandar, D. 2004. Metode Statistika dan Aplikasinya dengan Minitab dan Excel. Madyan Press. Yogyakarta.

Saefuddin, A., dkk. 2009. Statistika Dasar. Grasindo. Jakarta.

Sukirman, dkk.2008. Matematika. Universitas Terbuka. Jakrta. 


\section{BAB VI \\ DISTRIBUSI NORMAL}

\subsection{PENGANTAR}

Materi yang akan dibahas dalam bab ini adalah mengenai distribusi normal yaitu materi peluang nilai-nilai dalam distribusi normal standar dan nonstandar atau mengenai luas daerah di bawah kurva. Setelah mempelajari materi ini, Anda dapat menyelesaikan masalah yang menggunakan variabel acak kontinu dalam hal menentukan peluang dan luas daerah di bawah kurva, serta dapat membaca tabel distribusi normal.

\subsection{URAIAN MATERI}

\section{A. Distribusi Normal}

Distibusi normal merupakan distribusi peluang bagi variabel acak kontinu. Kurva Normal mempunyai bentuk seperti genta (lonceng) yang simetris (Gambar 1).

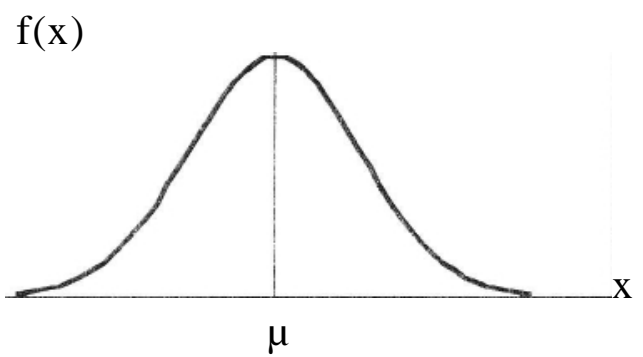

Gambar 1

Distribusi normal adalah distribusi variabel kontinyu dengan fungsi matematis

$$
f(x)=\frac{1}{\sigma \sqrt{2 \pi}} e^{-\frac{1}{2}\left(\frac{x-\mu}{\sigma}\right)^{2}} ;-\infty<x<\infty
$$

dimana $\pi=$ konstanta, sama dengan 3,1416

$e=$ konstanta, sama dengan 2,7183

$\mu=$ parameter, nilai rata-rata dari distribusi populasi

populasi

$\sigma=$ parameter, merupakan simpangan baku distribusi

$-\infty<x<\infty$

$x=$ peubah kontinu yang daerah (jangkauan) nilainya

Selain menggunakan metode integral, penghitungan probabilitas (peluang) distribusi normal juga bisa menggunakan tabel distribusi normal, yaitu tabel yang memuat probabilitas dari berbagai nilai variabel dalam distribusi normal. Metode ini lebih praktis untuk keperluan penelitian. Yang menjadi masalah dalam 
penyusunan tabel tersebut adalah kenyataan bahwa terdapat banyak sekali macam distribusi normal, dipengaruhi oleh besarnya nilai mean $(\mu)$ dan standar deviasinya/simpangan baku $(\sigma)$.

Suatu variabel (peubah) acak yang berdistribusi normal disebut sebagai variabel acak normal (normal random variable) dan mempunyai fungsi kepekatan/kepadatan peluang yang disebut sebagai fungsi kepekatan normal (normal density function). Sebuah variabel acak normal dapat mengambil sembarang nilai dalam sistem bilangan nyata, mulai dari $-\infty$ sampai $+\infty$. Suatu fungsi kepekatan normal dapat didefinisikan secara lengkap oleh nilai ratarata/mean/nilai harapan $(\mu)$ dan variansnya $\left(\sigma^{2}\right)$. Oleh karena itu, terdapat berbagai fungsi kepekatan normal yang berbeda antara satu dan lainnya jika nilai rata-ratanya atau variansnya berbeda. Gambar 2.a menunjukkan tiga fungsi kepekatan normal yang mempunyai varians yang sama tetapi nilai rata-ratanya berbeda, sedangkan Gambar 2.b menunjukkan tiga fungsi kepekatan normal yang mempunyai nilai rata-rata yang sama tetapi variansnya berbeda.

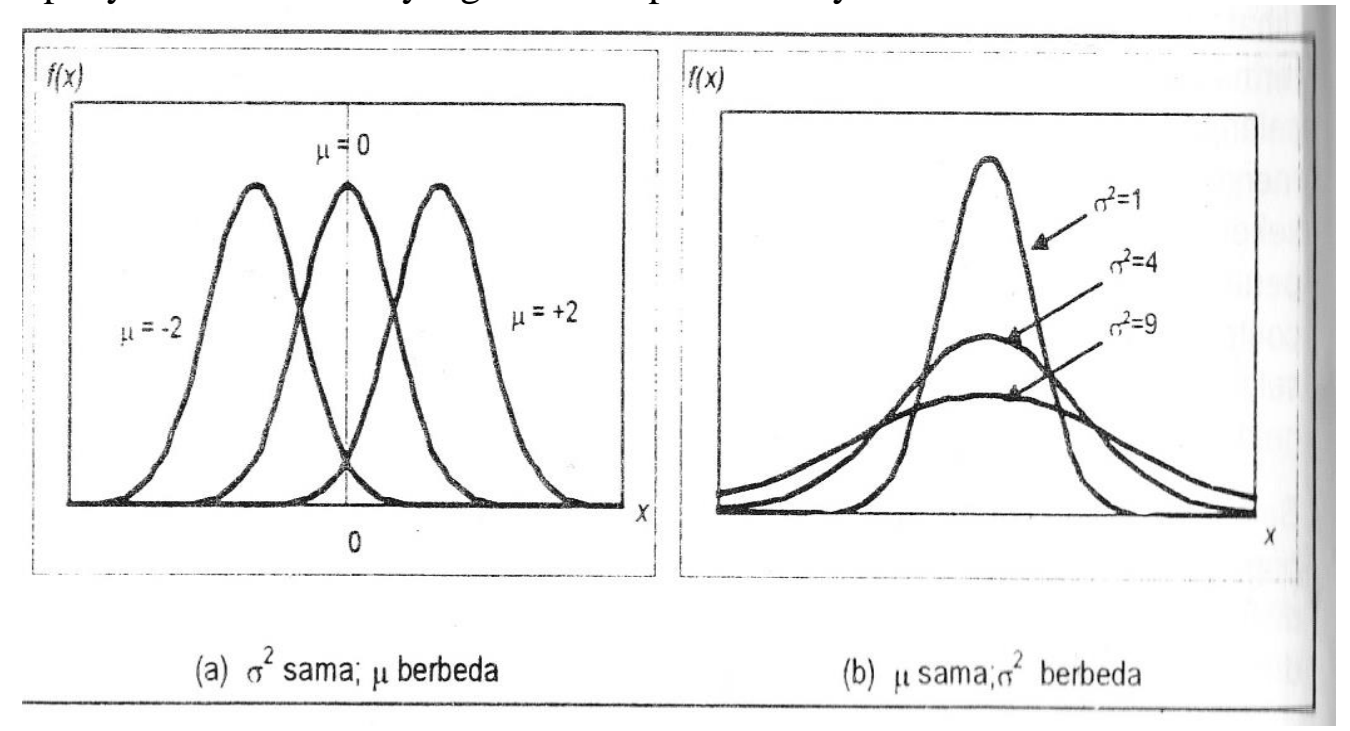

\section{Gambar 2}

Perhatikan bahwa ketiga kurva normal daiam gambar 2.a.mempunyai bentuk yang sama tetapi terpusat pada posisi yang berbeda. Sebaliknya, pada gambar 2.b ketiga kurva tersebut mempunyai pusat distribusi yang sama, tetapi bentuk distribusinya berbeda. Makin besar variansnya makin rendah bentuk kurvanya dan makin lebar distribusinya. Hal ini disebabkan karena luas di bawah kurva fungsi kepekatan peluang harus sama dengan satu.

Untuk mengatasi hal tersebut, maka para ahli hanya membuat satu buah tabel, yaitu tabel untuk menghitung nilai-nilai peluang distribusi normal standar, sedangkan jika kita akan menghitung peluang nilai-nilai variabel distribusi normal yang tidak standar, kita tetap bisa menggunakan tabel distribusi normal standar tersebut dengan memakai metode transformasii. Yang dimaksud distribusi normal standar adalah distribusi normal dengan sifat khusus, yaitu distribusi normal dengan mean $=0$ dan standar deviasi $=1$. 
Misalkan $X$ adalah sebuah variabel (peubah) acak normal dengan nilai rata-rata $\mu_{\mathrm{x}}$ dan varians $\sigma_{x}^{2}$, maka nilai-nilai peluang bagi $X$ ditentukan dengan luas di bawah kurva normal tersebut. Secara konvensional, penentuan nilai-nilai peluang $\mathrm{X}$ tersebut biasa dilakukan dengan menggunakan bantuan tabel bagi variabel normal baku (standard normal random variabel), yaitu suatu variabel acak yang berditribusi normal dengan $\mu=0$ dan $\sigma^{2}=1$. Tabel tersebut disajikan dalam Tabel Normal Baku 1 dan Tabel Normal Baku 2. Untuk dapat menggunakan tabel tersebut, variabel normal $\mathrm{X}$ harus ditransformasi agar mempunyai nilai rata-rata sama dengan 0 dan varians sama dengan 1 . Hal ini dapat dilakukan dengan transformasi berikut:

$$
z=\frac{x-\mu}{\sigma}
$$

Tabel Normal Baku 1 menyajikan nilai-nilai peluang (luas daerah di bawah kurva normal baku) bagi $\mathrm{Z}>\mathrm{z}$, yaitu $\mathrm{P}(\mathrm{Z}>\mathrm{z})$. Kolom pertama tabel tersebut mencantumkan nilai-nilai $\mathrm{z}$ dalam satu desimal, sedangkan desimal keduanya diletakkan sepanjang baris pertama dari tabel tersebut. Sebagai ilustrasi, untuk menentukan $\mathrm{P}(\mathrm{Z}>1,85)$, pertama-tama cari nilai $\mathrm{z}=1,8$ dalam kolom yang pertama (kolom paling kiri) dari Tabel 1 tersebut, kemudian cari pertemuan baris tersebut dengan kolom yang pada baris pertamanya benilai 0,05 . Pertemuan baris dan kolom tersebut menunjukkan angka 0,0322. Dengan demikian $P(Z>1,85)=$ 0,0322 .

\section{B. Menghitung Peluang (probabilitas) Nilai-nilai dalam Distribusi Normal Standar (Baku)}

Jika terdapat distribusi normal baku (variabelnya dilambangkan dengan $\mathrm{z}$ ), yaitu distribusi yang mempunyai mean $\mu=0$ dan standar deviasi $\sigma=1$, maka kita bisa langsung menggunakan tabel distribusi normal untuk mencari peluangnya.

\section{Contoh 1}

Suatu variabel berdistribusi normal dengan $\mu=0$ dan $\sigma=1$. Hitunglah peluang nilai $\mathrm{z}$ antara:

a. -1 sampai dengan 0

b. 1 sampai dengan 2

c. -1 sampai dengan 2

Penyelesaian :

a. Untuk mencari peluang antara 0 sampai dengan -1 , berarti $\mathrm{z}=-1$. Dalam membaca tabel, nilai $\mathrm{z}=-1$ kita baca sebagai nilai $\mathrm{z}=1$, sehingga peluangnya (luas di bawah kurva) adalah

$\mathrm{P}(-1<\mathrm{Z}<0)=\mathrm{P}(0<\mathrm{Z}<1)=0,3413$. 


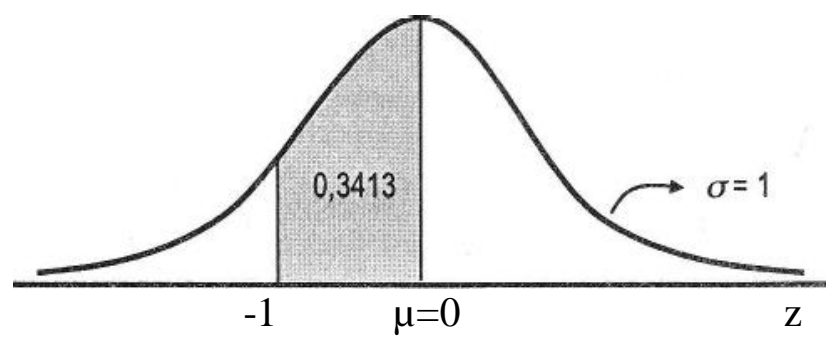

Gambar 3 Luas daerah di bawah kurva normal standar antara -1 dan 0

b. Untuk mencari peluang antara 1 sampai dengan 2 kita harus melalui dua tahap karena 1 dan 2 bukan nilai mean (rata-rata). Pertama, cari peluang antara 0 dan 2, kedua, cari peluang antara 0 dan 1, kemudian hasilnya dikurangkan

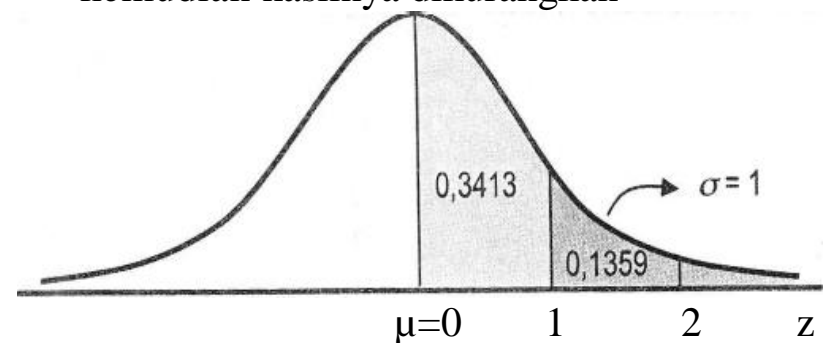

Gambar 4 Luas daerah di bawah kurva normal standar antara 1 dan 2

(1) $\mathrm{P}(0<\mathrm{Z}<1)=0,3413$.

(2) $\mathrm{P}(0<\mathrm{Z}<2)=0,4772$.

Maka peluang antara 1 dan 2 adalah

$\mathrm{P}(1<\mathrm{Z}<2)=0,4772-0,3413=0,1359$

c. Untuk mencari peluang antara -1 sampai dengan 2 kita harus melalui dua tahap karena -1 dan 2 bukan nilai mean. Pertama, cari peluang antara -1 dan 0 , kedua, cari peluang antara 0 dan 2 , kemudian hasilnya dijumlahkan.

(1) $\mathrm{P}(-1<\mathrm{Z}<0)=0,3413$.

(2) $\mathrm{P}(0<Z<2)=0,4772$

Maka peluang antara -1 dan 2 adalah

$\mathrm{P}(-1<\mathrm{Z}<2)=0,3413+0,4772=0,8185$

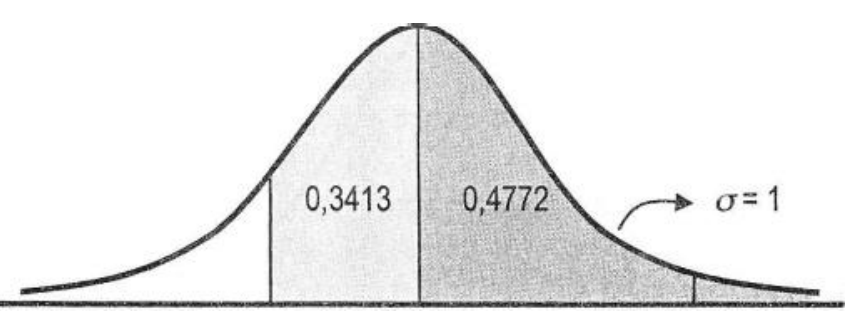

Gambar 5 Luas daerah di bawah kurva normal standar antara -1 dan 2
$-1 \quad \mu=0$
$2 \quad \mathrm{Z}$ 


\section{Menghitung Peluang Nilai-nilai dalam Distribusi Normal Non-Standar}

Distribusi normal non-standar adalah distribusi normal dengan dengan $\mu \neq 0$ at a u $\sigma \neq 1$ (variabelnya dilambangkan dengan $\mathrm{x}$ ). Untuk mencari probabilitas dalam distribusi tersebut, variabel $\mathrm{x}$ harus kita konversi ke nilai $\mathrm{z}$ dengan rumus:

$$
z=\frac{x-\mu}{\sigma}
$$

dimana $\mathrm{x}=$ nilai variabel yang hendak kita cari probabilitasnya, $u$ dan $\sigma$ masing-masing adalah rata-rata dan standar deviasi dari variabel $\mathrm{x}$.

\section{Contoh 2}

Diketahui suatu distribusi normal dengan $\mu=10$ dan $\sigma^{2}=4$. Hitunglah nilai-nilai :
a. antara 10 sampai dengan 12
c. antara 9 sampai dengan 13
b. antara 8 sampai dengan 10
d. antara 8 sampai dengan 9

Penyelesaian :

a. Antara 10 dan 12. Karena 10 adalah nilai mean, maka kita cukup mencari nilai $\mathrm{z}$ untuk $\mathrm{x}=12$.

$z=(\mathrm{x}-\mu) / \sigma=(12-10) / 2=2 / 2=1$

$\mathrm{P}(10<\mathrm{X}<12)=\mathrm{P}(0<\mathrm{Z}<1)=0,3413$.

Maka, peluang nilai-nilai antara 10 dan 12 adalah 0,3413.

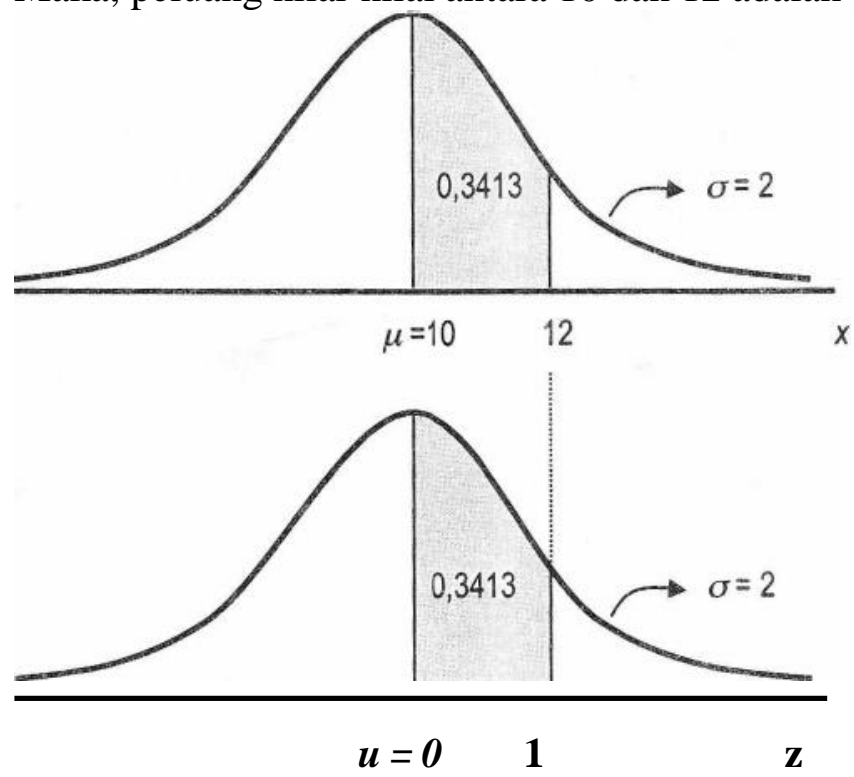

Gambar 6 Perbandingan antara distribusi normal standar dengan distribusi normal non-standar $\left(\mu=10, \quad \sigma^{2}=4, \quad x=10\right.$ d a n $\mathrm{x}=12$ )

b. Antara 8 dan 10 . Karena 10 adalah nilai mean, maka kita cukup mencari nilai $\mathrm{z}$ untuk $\mathrm{x}=8$.

$z=(\mathrm{x}-\mu) / \sigma=(8-10) / 2=-2 / 2=-1$

$\mathrm{P}(8<\mathrm{X}<10)=\mathrm{P}(-1<\mathrm{Z}<0)=\mathrm{P}(0<\mathrm{Z}<1)=0,3413$ 


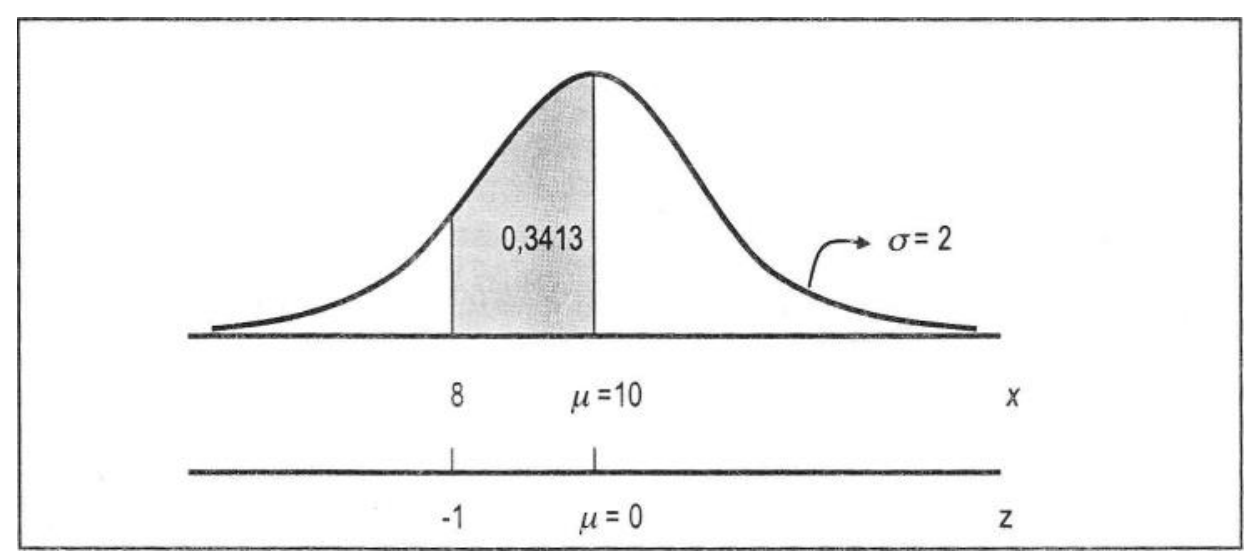

Gambar 7 Perbandingan antara distribusi normal standar dengan distribusi normal non-standar $\left(\mu=10, \quad \sigma^{2}=4, \quad x=8\right.$ d a n $\mathrm{x}=10$ )

c. Antara 9 dan 13. Karena 9 dan 13 bukan nilai rata-rata, maka kasus ini harus kita selesaikan dalam dua tahap: pertama, cari peluang antara 9 dan 10; kedua, cari peluangnya antara 10 dan 13, kemudian hasil pada dua tahap tersebut kita jumlahkan

(1) Antara 9 dan 10

$$
z=(\mathrm{x}-\mu) / \sigma=(9-10) / 2=-1 / 2=-0,5
$$

$$
\mathrm{P}(9<\mathrm{X}<10)=\mathrm{P}(-0,5<\mathrm{Z}<0)=\mathrm{P}(0<\mathrm{Z}<0.5)=0,1915
$$

(2) Antara 10 dan 13

$$
\begin{aligned}
z=(\mathrm{x}-\mu) / \sigma=(13-10) / 2=3 / 2=1,5 \\
\mathrm{P}(10<\mathrm{X}<13)=\mathrm{P}(0<\mathrm{Z}<1,5)=0,4332
\end{aligned}
$$

Maka nilai peluang antara 9 dan 13 adalah

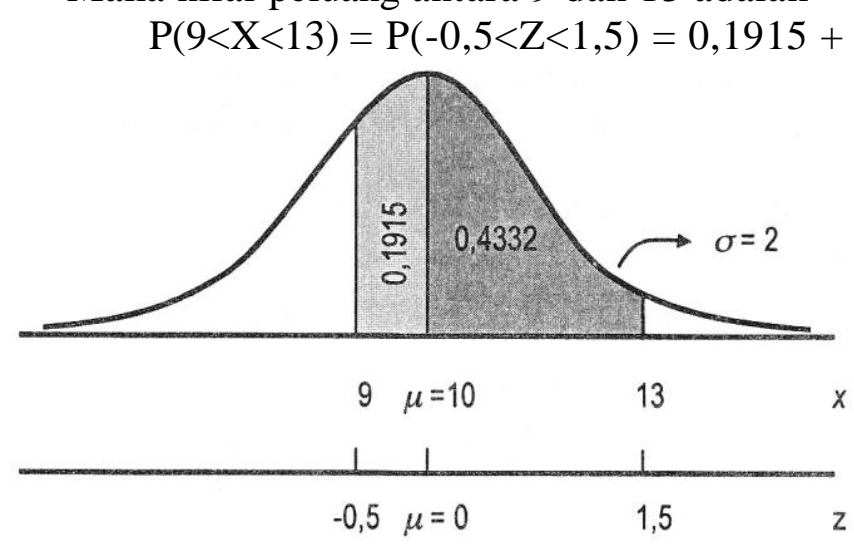

Gambar 8 Perbandingan antara distribusi normal standar dengan distribusi normal non-standar $\left(\mu=10, \quad \sigma^{2}=4, \quad \mathrm{x}=9\right.$ d a n $\mathrm{x}=13$ )

d. Antara 8 dan 9. Karena 8 dan 9 bukan nilai rata-rata, maka kasus ini harus kita selesaikan dalam dua tahap: pertama, cari peluang antara 8 dan 10; kedua, cari peluangnya antara 9 dan 10, kemudian hasil pada dua tahap tersebut kita kurangkan.

(1) $\mathrm{P}(8<\mathrm{X}<10)=\mathrm{P}(-1<\mathrm{Z}<0)=0,3413$ (sama dengan soal $\mathrm{b}$ di atas)

(2) $\mathrm{P}(9<\mathrm{X}<10)=\mathrm{P}(-0,5<\mathrm{Z}<0)=0,1915$ (sama dengan soal $\mathrm{c}(1))$

Maka nilai peluang antara 8 dan 9 adalah

$\mathrm{P}(8<\mathrm{X}<9)=\mathrm{P}(-1<\mathrm{Z}<-0,5) 0,3413-0,1915=0,1498$. 


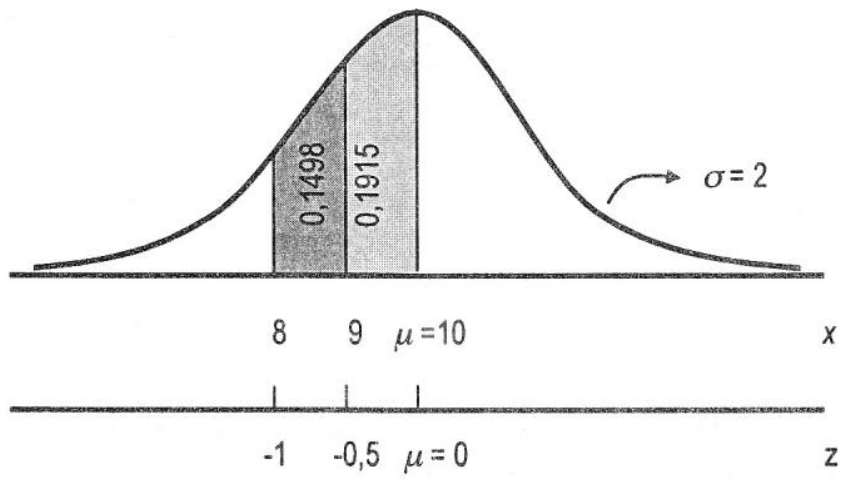

Gambar 9 Perbandingan antara distribusi normal standar dengan distribusi normal non-standar $\left(\mu=10, \quad \sigma^{2}=4, \quad \mathrm{x}=8\right.$ d a n $\mathrm{x}=9$ )

Contoh di atas (Contoh 1 dan 2), dijawab berdasarkan Tabel Normal Baku 2. Jika menggunakan Tabel Normal Baku 1, maka hasilnya tetap sama jika menggunakan Tabel Normal Baku 2, hanya cara penyelesaiannya sesuai dengan jenis tabel yang akan digunakan (Tabel Normal Baku 1).

Untuk Contoh 2 bagian $\mathbf{c}$ dan d, dapat diperlihatkan pengerjaannya sebagai berikut :

\section{c. Antara 9 sampai dengan 13}

$$
\begin{aligned}
& z=(\mathrm{x}-\mu) / \sigma=(9-10) / 2=-1 / 2=-0,5 \\
& z=(\mathrm{x}-\mu) / \sigma=(13-10) / 2=3 / 2=1,5 \\
& \text { maka nilai peluangnya adalah } \\
& \begin{aligned}
\mathrm{P}(9<\mathrm{X}<13)=\mathrm{P}(-0,5<\mathrm{Z}<1,5) & =1-\mathrm{P}(\mathrm{Z}<-0,5)-\mathrm{P}(\mathrm{Z}>1,5) \\
& =1-\mathrm{P}(\mathrm{Z}>0,5)-\mathrm{P}(\mathrm{Z}>1,5) \\
& =1-0,3085-0,0668=0,6247
\end{aligned}
\end{aligned}
$$

\section{d. antara 8 sampai dengan}

$$
\begin{aligned}
& z=(\mathrm{x}-\mu) / \sigma=(8-10) / 2=-2 / 2=-1 \\
& z=(\mathrm{x}-\mu) / \sigma=(9-10) / 2=-1 / 2=-0,5 \\
& \text { maka nilai peluangnya adalah } \\
& \begin{aligned}
\mathrm{P}(8<\mathrm{X}<9)=\mathrm{P}(-1<\mathrm{Z}<-0,5) & =\mathrm{P}(\mathrm{Z}<-0,5)-\mathrm{P}(\mathrm{Z}<-1) \\
& =\mathrm{P}(\mathrm{Z}>0,5)-\mathrm{P}(\mathrm{Z}>1) \\
& =0,3085-0,1587=0,1498
\end{aligned}
\end{aligned}
$$

\section{Contoh 3}

Diketahui gaji karyawan per bulan pada suatu perusahaan tertentu berdistribusi normal dengan rata-rata Rp. 1,73 juta dengan simpangan baku Rp. 200 ribu. Tentukan peluang bahwa seorang karyawan yang dipilih secara acak akan mempunyai gaji per bulan lebih kecil dari Rp. 1,5 juta.

\section{Penyelesaian}

$z=(\mathrm{x}-\mu) / \sigma=(1.500 .000-1.730 .000) / 200.000=-1,15$ Oleh karena itu, $\mathrm{P}(\mathrm{X}<1.500 .000)=\mathrm{P}(\mathrm{Z}<-1,15)=\mathrm{P}(\mathrm{Z}>1,15)=0,1251$. Sehingga peluang bahwa seorang karyawan yang dipilih secara acak akan mempunyai gaji per bulan lebih kecil dari Rp. 1,5 juta adalah 0,1251. 


\section{BAB VII ANALISIS KOMPONEN UTAMA (PRINCIPAL COMPONENT ANAL YSIS)}

\subsection{PENGANTAR}

Dalam bab ini akan dibaahs berkaitan dengan analisis kompoenen utama (principal component analysis) yang merupakan salah satu analisis peubah ganda. Analisis peubah ganda atau analisis multivariat (multivariate analysis) merupakan analisis statistika yang menyertakan lebih dari satu peubah. Dalam analisis peubah ganda sering terjadi multikolinieritas, masalah multikolinieritas muncul ketika terdapat korelasi di antara peubah bebasnya, sehingga hal ini akan mempengaruhi ragam dari penduga kuadrat terkecil dan penduga model yang dibuat. Salah satu cara untuk mengatasi multikolinieritas adalah dengan menggunakan Analisis Komponen Utama. Analisis ini merupakan Analisis Peubah Ganda yang tertua, diperkenalkan oleh Garson pada tahun 1901, selanjutnya dikembangkan oleh Hotelling pada tahun 1933 dan Rao dkk pada tahun 1964. Konsep analisis Komponen Utama yang diterapkan terhadap vektor acak dikembangkan oleh Hotelling, sedangkan Rao menghadirkan penerapan analisis komponen utama di berbagai bidang terapan dan memberikan landasan matematika formal yang lebih kokoh. Sebagai salah satu teknik analisis peubah ganda, penggunaan analisis komponen utama semakin meluas dengan semakin mudahnya mendapatkan fasilitas komputasi berkecepatan tinggi oleh para peneliti.

\subsection{URAIAN MATERI}

Pada dasarnya, analisis komponen utama (principal component analysis) bertujuan menerangkan struktur ragam-peragam melalui kombinasi linier dari variabel-variabel. Secara umum, analisis komponen utama bertujuan untuk mereduksi data khususnya peubah dan menginterpretasikannya. Meskipun dari $\mathrm{p}$ buah variable asal dapat diturunkan $\mathrm{p}$ buah komponen utama untuk menerangkan keragaman total sistem, namun sering kali keragaman total itu dapat diterangkan oleh sejumlah kecil komponen utama, katakanlah olek $\mathrm{k}$ komponen utama, dimana $\mathrm{k}<\mathrm{p}$.

Dalam bab ini Anda akan mempelajari analisis komponen utama yang mencakup materi-materi bahasan sebagai berikut : Konsep Dasar Analisis Komponen Utama, Model Komponen Utama, dan Penentuan Banyaknya Komponen Utama.

\section{A. Konsep Dasar Analisis Komponen Utama}

Komponen Utama adalah kombinasi linier dari peubah yang diamati. Analisis komponen utama adalah metode analisis peubah ganda yang bertujuan memperkecil dimensi peubah asal sehingga diperoleh peubah baru (komponen utama) yang tidak saling berkorelasi dengan tetap menyimpan sebagian besar informasi yang terkandung pada peubah asal. Misalkan $\mathrm{X}_{1}, \mathrm{X}_{2}, \mathrm{X}_{3}, \ldots, \mathrm{X}_{\mathrm{p}}$ adalah peubah acak yang menyebar menurut sebaran tertentu dengan vektor nilai tengah $\mu$ dan matriks kovarian $\sum$. Komponen utama merupakan kombinasi linier 
terboboti dari peubah-peubah asal yang mampu menerangkan data secara maksimum.

Komponen Utama ke-j dari p peubah dapat dinyatakan sebagai :

$$
Y_{j}=a_{1 j} X_{1}+a_{2 j} X_{2}+\ldots+a_{p j} X_{p}=\underline{\mathbf{a}} \underline{\underline{x}}
$$

dan keragaman Komponen Utama ke-j dari p peubah dapat dinyatakan sebagai :

$$
\operatorname{Var}\left(\mathrm{Y}_{\mathrm{j}}\right)=\lambda_{\mathrm{j}} ; \mathrm{j}=1,2, \ldots, \mathrm{p}
$$

$\lambda_{1}, \lambda_{2}, \ldots, \lambda_{\mathrm{p}}$ adalah akar ciri (nilai eigen) yang diperoleh dari persamaan

$$
\left|\sum-\lambda_{\mathrm{j}} \mathrm{I}\right|=0 \text {, di mana } \lambda_{1} \geq \lambda_{2} \geq \ldots . . \geq \lambda_{\mathrm{p}} \geq 0 \text {. }
$$

Vektor ciri (vektor eigen) a sebagai pembobot dari transformasi linier peubah asal diperoleh dari persamaan $\left(\sum-\lambda_{\mathrm{j}} \mathrm{I}\right) \underline{\mathbf{a}}_{\mathrm{j}}=0$

Total keragaman komponen utama adalah :

$\left(\lambda_{1}+\lambda_{2}+\ldots . .+\lambda_{\mathrm{p}}\right)=\operatorname{tr}\left(\sum\right)$

dan persentase total keragaman data yang mampu diterangkan oleh komponen utama ke-j adalah : $\left(\frac{\lambda_{j}}{\operatorname{tr}(\Sigma)} \times 100 \%\right)$. Persentase keragaman dianggap cukup mewakili jika total keragaman data $75 \%$ atau lebih.

Korelasi antara peubah ke-i dengan komponen utama ke-j dinyatakan sebagai :

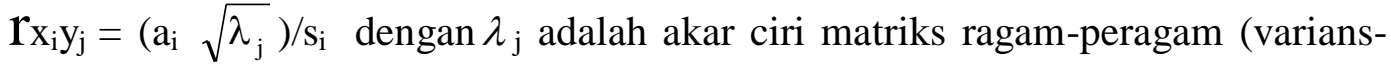
kovarians) $\mathrm{S}$ (penduga $\sum$ ).

Pembangkitan komponen utama tergantung dari jenis data asal yang digunakan. Apabila data yang digunakan memiliki satuan pengukuran yang sama, maka digunakan matriks ragam-peragam, dan jika tidak sama maka digunakan matriks korelasi. Komponen utama yang dihasilkan dengan menggunakan matriks peragam merupakan kombinasi linier dari peubah asal X. Komponen Utamanya ditulis dalam bentuk $\mathrm{K}=\mathrm{f}(\mathrm{X})$. Komponen utama yang dibangkitkan dari matriks korelasi merupakan kombinasi linier nilai baku $Z$ dari peubah asal yaitu $K=f(Z)$, dan $Z$ adalah fungsi dari $X$, di mana $Z=\frac{X_{j}-\bar{X}}{s}$.

\section{Komponen Utama yang Dibangkitkan dari Matriks Ragam-Peragam}

Tahapan :

1. Membuat matriks ragam-peragam $\left(\sum\right)$ dari ragam setiap peubah.

2. Mencari akar ciri $(\lambda)$ dan vektor ciri (a) dari matriks ragam peragam $(\Sigma)$.

3. Menentukan persamaan Komponen Utama dari vektor ciri.

4. Menentukan Komponen Utama yang akan dipilih berdasarkan total keragaman yang dapat diterangkan oleh Komponen Utama tersebut.

5. Mencari peubah yang paling berpengaruh dari setiap Komponen Utamanya.

\section{Komponen Utama yang Dibangkitkan dari Matriks Korelasi}

Secara garis besar, tahap-tahap Komponen Utama yang dibangkitkan dari matriks korelasi sama dengan Komponen Utama yang dibangkitkan dari matriks ragam-peragam. Hanya saja data asal ditransformasi terlebih dahulu menjadi nilai baku Z, melalui transformasi : $\mathrm{Z}=\frac{\mathrm{X}_{\mathrm{j}}-\overline{\mathrm{X}}}{\mathrm{s}}$

Sedangkan matriks pertama yang dibuat adalah matriks korelasi $\rho$. 
Tahapan selanjutnya sama dengan Komponen Utama dari matriks ragamperagam. Dalam banyak literatur seringkali dianjurkan untuk menggunakan matriks korelasi.

\section{B. Model Komponen Utama}

Andaikan bahwa kita memiliki $\mathrm{p}$ buah variabel asal $\mathrm{X}$, yaitu $X_{1}, X_{2}, \ldots, X_{p}$ dimana diasumsikan bahwa :

$$
\underline{\mathrm{X}} \sim \mathrm{N}_{\mathrm{p}}(\underline{\mu}, \Sigma), \quad \underline{X}^{\prime}=\left(X_{1}, X_{2}, \ldots, X_{p}\right)
$$

$\mathrm{E}(\mathrm{X})=\underline{\mu}, \quad \operatorname{Cov}(\mathrm{X})=\Sigma$

Dalam bentuk pernyataan dikatakAn bahwa vektor $\mathrm{X}$ berdistribusi multinormal dengan vektor rataan $\underline{\mu}$ dan matriks peragam $\Sigma$. Jika kita mendefinisikan A sebagai matriks konstan berukuran $p \times p$, maka komponen utama didefinisikan sebagai kombinasi linier dari variabel asal ( $\mathrm{p}$ buah variabel asal) yang dinyatakan dalam bentuk persamaan matriks, sebagai berikut :

$$
\underline{Y}=\mathrm{A} \underline{X}
$$

Dalam bentuk yang lebih jelas, maka persamaan (1) dapat dinyatakan sebagai berikut:

$$
\begin{aligned}
& Y_{1}=a_{11} X_{1}+a_{21} X_{2}+\ldots+a_{p 1} X_{p} \\
& Y_{2}=a_{11} X_{1}+a_{22} X_{2}+\ldots+a_{p 2} X_{p} \\
& \text { : : : : : } \\
& \dot{Y}_{p}=a_{1 p} X_{1}+a_{2 p} X_{2}+\ldots+a_{p p} X_{p}
\end{aligned}
$$

Jika didefinisikan $\underline{Y}=\mathrm{A} \underline{\mathrm{X}}$, sedangkan diketahui bahwa $\operatorname{Cov}(\mathrm{X})=\Sigma$, maka diperoleh :

$\operatorname{Cov}(\mathrm{Y})=\mathrm{A} \Sigma \mathrm{A}^{\prime}$ atau dapat juga dinyatakan sebagai :

$\operatorname{Cov}(\mathrm{Y})=\sum_{1=1}^{p} \sum_{j=1}^{p} a_{i} a_{j} \sigma_{i j}$

Jika analisis komponen utama dilakukan terhadap data contoh (sample), maka matriks peragam $\Sigma$ dapat diduga dengan matriks $S$ berikut :

$$
\begin{aligned}
& S=\frac{1}{n-1} \sum_{h=1}^{n}\left(x_{h}-\bar{x}\right)\left(x_{h}-\bar{x}\right)^{\prime} \\
& n=\text { ukuran contoh (sample) }
\end{aligned}
$$

Selanjutnya didefinisikan komponen utama pertama sebagai kombinasi linier variabel asal yang dinyatakan sebagai berikut :

$$
\begin{aligned}
& Y_{1}=a_{11} X_{1}+a_{21} X_{2}+\ldots+a_{p 1} X_{p} \\
& =a_{1}^{\prime} x \\
& s_{Y_{1}}^{2}=\sum_{i=1}^{p} \sum_{j=1}^{p} a_{i 1} a_{j 1} s_{i j} \\
& \quad=a_{1}^{\prime} S a_{1}
\end{aligned}
$$

Kita menginginkan agar ragam komponen pertama maksimum untuk semua koefisien normal $a_{1}{ }^{\prime} a_{1}=1$. Permasalahan sekarang adalah bagaimana menentukan vektor koefisien komponen utama pertamam $\mathrm{Y}_{1}$, yang memaksimumkan ragam komponen utama pertama $S_{Y_{1}}$, dengan kendala $a_{1}{ }^{\prime} a_{1}=1$. Persoalan ini dapat diselesaikan menggunakan fungsi Lagrange (metode pengganda Lagrange). Jadi perumusan masalah secara matematik adalah :

$$
\text { Maksimum } s_{Y_{1}}^{2}=\mathrm{a}_{1} ’ \mathrm{~S} \mathrm{a}_{1}
$$


dengan kendala : $\mathrm{a}_{1} \mathrm{a}_{1}=1$ atau $\mathrm{a}_{1}{ }^{\prime} \mathrm{a}_{1}-1=0$

Fungsi Lagrange dibentuk sebagai berikut :

$$
\mathrm{L}=\mathrm{a}_{1}, \mathrm{~S} \mathrm{a}_{1}-\lambda_{i}\left(\mathrm{a}_{1}{ }^{\prime} \mathrm{a}_{1}-1\right)
$$

Apabila $\mathrm{L}$ diturunkan terhadap vektor $\mathrm{a}_{1}$, maka diperoleh :

$$
\begin{aligned}
& \frac{\partial L}{\partial a_{1}}=2 a_{1}^{\prime} S-2 \lambda_{1} a_{1}=0 \\
& =2\left(S-\lambda_{1} I\right) a_{1}=0 \\
& =\left(S-\lambda_{1} I\right) a_{1}=0
\end{aligned}
$$

Dengan demikian untuk memperoleh vektor koefisien kompoen utama pertama, $\mathrm{Y}_{1}$, yang memaksimumkan ragam komponen utama pertama, $s_{Y_{1}}^{2}$, dengan kendala $a_{1}{ }^{\prime} a_{1}=1$, maka kita perlu menyelesaikan persamaan linier berikut yang merupakan hasil diferensiasi dari fungsi Lagrange terhadap vektor $\mathrm{a}_{1}$;

$$
\left(S-\lambda_{1} I\right) a_{1}=0
$$

Persamaan (5) dikenal sebagai persamaan ciri (characteristic equation) dari matriks peragam $S, \lambda_{1}$ adalah akar ciri dari matriks $S, a_{1}$ adalah vektor ciri dari matriks $\mathrm{S}$ sedangkan I adalah matriks identitas.

Agar persamaan (5) menghasilkan solusi yang tidak sama dengan nol untuk nilai $a_{1}$, maka matriks $\left(S-\lambda_{1} I\right)$ haruslah merupakan matriks singular yaitu matriks yang tidak mempunyai invers. Hal ini berarti, haruslah determinan dari matriks itu sama dengan nol Jadi, haruslah :

$$
\left|S-\lambda_{1} I\right|=0
$$

Dengan demikian haruslah dipenuhi konsep determinan $\left|S-\lambda_{1} I\right|=0$ agar diperoleh solusi $\mathrm{a}_{1}$ tidak trivial. Dari persamaan (5), bentuk $S$ dikenal sebagai matriks peragam dugaan sebagai penduga bagi matriks peragam populasi $\Sigma, \lambda_{1}$ adalah akar ciri dari matriks $S, a_{1}$ adalah vektor ciri dari matriks S. Penentuan akar ciri mana dari $\mathrm{p}$ buah akar ciri yang ada untuk dipergunakan dalam komponen utama pertama, dilakukan dengan jalan menggandaawalkan (premultiply) sistem persamaan (5) dengan a sebagai berikut :

Persamaan : $\left(S-\lambda_{1} I\right) a_{1}=0$
diubah menjadi $; S a_{1}-\lambda_{1} I a_{1}=0$

$S a_{1}=\lambda_{1} I a_{1}$

Jika kedua sisi persamaan (7) digandaawalkan dengan $a_{1}^{\prime}$ akan menjadi :

$$
a_{1}^{\prime} S a_{1}=a_{1}^{\prime} \lambda_{1} I a_{1}
$$

karena telah diberikan batasan bahwa $a_{1}^{\prime} a_{1}=1$ maka diperoleh :

$$
a_{1}^{\prime} S a_{1}=\lambda_{1}
$$

Dengan demikian diperoleh :

$$
\lambda_{1}=a_{1}^{\prime} S a_{1}=S_{Y_{1}}^{2}
$$

Dari persamaan (8) tampak bahwa agar ragam komponen utama maksimum maka haruslah dipilih akar ciri terbesar dari matriks $\mathrm{S}$.

Berdasarkan kenyataan di atas maka dapat dibuat pernyataan berikut :

Komponen utama pertama adalah kombinasi libear variabel asal yang dapat menerangkan keragaman terbesar. Komponen utama pertama dapat dituliskan sebagai : 


$$
\begin{aligned}
& Y_{1}=a_{11} X_{1}+a_{21} X_{2}+\ldots+a_{1 p} X_{p} \\
& =a_{1}^{\prime} x
\end{aligned}
$$

Vektor $a_{1}^{\prime}$ adalah vektor normal serta $a_{1}^{\prime} a_{1}=1$ dipilih agar keragaman komponen utama menjadi maksimum.

Ragam komponen pertama adalah :

$$
s_{Y_{1}}^{2}=\sum_{i=1}^{p} \sum_{j=1}^{p} a_{i 1} a_{j 1} s_{i j}=a_{1}^{\prime} S a_{1}=\lambda_{1}
$$

Selanjutnya degan prosedur yang sama, kita dapat membentuk komponen utama kedua, $\mathrm{Y}_{2}$.

Komponen utama kedua didefinisikan sebagai kombinasi linier variabel asal yang dinyatakan sebagai berikut :

$$
\begin{aligned}
& Y_{2}=a_{12} X_{1}+a_{22} X_{2}+\ldots+a_{p 2} X_{p} \\
& =a_{2}^{\prime} x \\
& s_{Y_{2}}^{2}=\sum_{i=1}^{p} \sum_{j=1}^{p} a_{i 2} a_{j 2} s_{i j} \\
& =a_{2}^{\prime} S a_{2}
\end{aligned}
$$

Kita menginginkan juga agar ragam komponen utama kedua maksimum untuk semua koefisien normal $a_{2}^{\prime} a_{2}=1$ serta komponen utama kedua tidak berkorelasi dengan komponen utama pertama yang berarti haruslah $a_{1}^{\prime} a_{2}=0$. Sehingga permasalahannya sekarang adalah bagaimana memnentukan vektor koefisien komponen utama kedua $Y_{2}$, yang memaksimumkan ragam komponen utama kedua $s_{Y_{2}}^{2}$, serta orthogonal terhadap komponen utama pertama, jadi diberikan kendala $a_{2}^{\prime} a_{2}=1$ dan $a_{1}^{\prime} a_{2}=0$. Permasalahan di atas dapat diselesaikan menggunakan fungsi Lagrange dengan merumuskan persoalan secara matematik sebagai berikut :

Maksimum : $s_{Y_{2}}^{2}=a_{2}^{y} S a_{2}$

dengan kendala : $a_{2}^{\prime} a_{2}=1$ atau $a_{2}^{\prime} a_{2}-1=0$

$a_{2}^{\prime} a_{2}=0$

Fungsi Lagrange dibentuk sebagai berikut :

$$
L=a_{2}^{\prime} S a_{2}-\lambda_{2}\left(a_{2}^{\prime} a_{2}-1\right)-u a_{1}^{\prime} a_{2}
$$

Selanjutnya L diturunkan terhadap vektor $a_{2}$, sehingga diperoleh :

$$
\begin{aligned}
& \frac{\partial L}{\partial a_{2}}=2 a_{2}^{\prime} S-2 \lambda_{2} a_{2}-u a_{1}=0 \\
& =2\left(S-\lambda_{2} I\right) a_{2}-u a_{1}=0 \\
& =\left(S-\lambda_{2} I\right) a_{2}-u a_{1}=0
\end{aligned}
$$

Selanjutnya, apabila hasil diferensiasi di atas digandaawalkan dengan vektor $a_{1}^{\prime}$ akan diperoleh :

$a_{1}^{\prime} S a_{2}-a_{1}^{\prime} \lambda_{2} I a_{2}-a_{1}^{\prime} u a_{1}=0$

Karena kita mengetahui dari kendala bahwa : $a_{1}^{\prime} a_{2}=0$ serta $a_{2}^{\prime} a_{2}=1$, maka hasil penggandaawalan dengan vektor $a_{1}^{\prime}$ adalah :

$$
0-0-u=0 \text { atau } u=0
$$

Jika $u=0$ berarti hasil diferensiasi dari fungsi Lagrange terhadap vektor $a_{2}$ akan menjadi :

$$
\left(S-\lambda_{2} I\right) a_{2}=0
$$


Dengan demikian permasalahannya sekarang adalah bagaimana memecahkan sistem persamaan (10). Persamaan (10) akan mempunyai solusi yang tidak sama dengan nol untuk nilai $a_{2}$ apabila dipenuhi syarat bahwa $\left(S-\lambda_{2} I\right)$ adalah merupakan matriks singular yang tidak mempunyai invers. Hal ini berarti, haruslah determinan dari matriks itu sama dengan nol, jadi harulah dipenuhi :

$$
\left|S-\lambda_{2} I\right|=0
$$

Dengan demikian kita harus menyelesaikan sistem persamaan ciri (10) untuk membangun komponen utama kedua yang memenuhi criteria memiliki ragam komponen utama maksimum dan tidak berkorelasi dengan komponen utama pertama.

Jika sistem persamaan (10) digandaawalkan dengan $a_{2}^{\prime}$ akan diperoleh :

$$
\begin{aligned}
& a_{2}^{\prime} S a_{2}-a_{2}^{\prime} \lambda_{2} I a_{2}=0 \\
& a_{2}^{\prime} S a_{2}=a_{2}^{\prime} \lambda_{2} I a_{2}
\end{aligned}
$$

Karena telah diberikan batasan bahwa $a_{2}^{\prime} a_{2}=1$, maka diperoleh :

$$
a_{2} S a_{2}=\lambda_{2}
$$

Dengan demikian diperoleh hasil :

$$
\lambda_{2}=a_{2} S a_{2}=s_{Y_{2}}^{2}
$$

Dengan demikian diketahui bahwa agar ragam komponen utama kedua maksimum perlu dipilih akar ciri $\lambda_{2}$ terbesar. $\lambda_{2}$ adalah akar ciri terbesar kedua setelah $\lambda_{1}$. Jadi, dalam hal ini $\lambda_{1}>\lambda_{2}$.

Berdasarkan uraian yang dikemukakan, maka dapat dibuat penyataan berikut. Komponen utama kedua adalah kombinasi linear variabel asal yang tidak berkorelasi dengan komponen utama pertama serta memaksimumkan sisa keragaman data setelah diterangkan oleh komponen utama pertama. Komponen utama kedua dapat ditulis sebagai :

$$
\begin{aligned}
Y_{2} & =a_{12} X_{1}+a_{22} X_{2}+\ldots+a_{p 2} X_{p} \\
& =a_{2}^{\prime} x
\end{aligned}
$$

Vektor $a_{2}^{\prime}$ adalah vektor normal yang dipilih sehingga keragaman komponen utama kedua maksimum serta orthogonal terhadap vektor $a_{1}^{z}$ dari komponen utama pertama. Agar komponen utama kedua maksimum serta antara komponen utama kedua tidak berkorelasi dengan komponen utama pertama, maka vektor $a_{2}^{\prime}$ haruslah dipilih dengan kendala $a_{2}^{\prime} a_{2}=1$ dan $a_{1}^{\prime} a_{2}=0$.

Ragam komponen utama kedua adalah :

$$
s_{Y_{2}}^{2}=\sum_{i=1}^{p} \sum_{j=1}^{p} a_{i 2} a_{j 2} s_{i j}=a_{2}^{\prime} S a_{2}=\lambda_{2}
$$

Koefisien $a_{i 2}$ adalah elemen-elemen dari vektor ciri yang berhubungan dengan akar ciri terbesar kedua, $\lambda_{2}$, yang diturunkan dari matriks peragam S. Jika koefisien $a_{i 2}$ dinormalkan sehingga $a_{2}^{\prime} a_{2}=1$, maka akar ciri $\lambda_{2}$ dapat diinterpretasikan sebagai ragam contoh (sample variance) dari komponen utama kedua, $Y_{2}$. 
Secara umum dengan prosedur serupa, vektor komponen utama ke-j $(j=1,2$, $\ldots$, p) yaitu $a_{j}^{\prime}$ ditentukan dengan jalan menyelesaikan sistem persamaan berikut :

$$
\left(s-\lambda_{j} I\right) a_{j}=0
$$

Agar persamaan (12) menghasilkan vektor $a_{j}$ yang tidak sama dengan nol maka haruslah dipenuhi syarat bahwa determinan dari matriks $\left(s-\lambda_{j} I\right)$ sama dengan nol, jadi : $\left|S-\lambda_{j} I\right|=0$

Jika persamaan (13) diganda awalkan dengan vektor $a_{j}^{\prime}$, maka akan menghasilkan :

$$
\begin{aligned}
& a_{j}^{\prime} S a_{j}-a_{j}^{\prime} \lambda_{j} I a_{j}=0 \\
& a_{j}^{\prime} S a_{j}=a_{j}^{\prime} \lambda_{j} I a_{j}
\end{aligned}
$$

Dengan memberikan batasan $a_{j}^{\prime} a_{j}=1$ maka diperoleh :

$$
a_{j}^{\prime} S a_{j}=\lambda_{j}
$$

Dengan demikian diperoleh hasil :

$$
\lambda_{j}=a_{j} S a_{j}=s_{Y_{j}}^{2}
$$

Berdasarkan kenyataan di atas maka dapat dibuatkan pernyataan umum yang berkaitan dengan konsep analisis komponen utama sebagai berikut :

Komponen utama ke- $\mathrm{j}(\mathrm{j}=1,2, \ldots, \mathrm{p})$ dari contoh pengamatan berdimensi $\mathrm{p}$ variabel adalah merupakan kombinasi linier variable asal yang dinyatakan dalam bentuk persamaan berikut :

$$
\begin{aligned}
& Y_{1}=a_{1 j} X_{1}+a_{2 j} X_{2}+\ldots+a_{p j} X_{p} \\
& =a_{j}^{\prime} x
\end{aligned}
$$

Vektor $a_{j}^{\prime}$ adalah vektor normal yang dipilih sehingga keragaman komponen utama ke-j maksimum serta ortogonal terhadap vektor $a_{i}^{z}$ dari komponen utama ke-i $(i \neq j, i, j=1,2, \ldots, p)$. Agar ragam dari komponen utama ke-j tidak berkorelasi dengan komponen utama ke-i untuk $i \neq j$ maka vektor $a_{j}^{\prime}$ haruslah dipilih dengan kendala :

$$
a_{j}^{\prime} a_{j}=1 \text { serta } a_{i}^{\prime} a_{j}=0 \text {, untuk } i \neq j, i, j=1,2, \ldots, p
$$

Dengan kendala di atas maka akar ciri $\lambda_{j}$ dapat diinterpretasikan sebagai ragam komponen utama ke-j serta sesama komponen utama tidak berkorelasi. Dengan demikian berlaku :

$$
\begin{aligned}
& \lambda_{j}=a_{j} S a_{j}=s_{Y_{j}}^{2} \\
& \operatorname{cov}\left(Y_{i}, Y_{j}\right)=0, \text { untuk } \mathrm{i} \neq \mathrm{j}(\mathrm{i}, \mathrm{j}=1,2, \ldots, \mathrm{p})
\end{aligned}
$$

\section{Komponen Utama dengan Variabel yang Distandarisasi}

Matriks peragam $\mathrm{S}$ digunakan dalam analisis komponen utama apabila semua variabel yang diamati ( $\mathrm{p}$ buah variabel) diukur dalam satuan pengukuran yang sama. Jika dari $\mathrm{p}$ buah variabel yang diamati itutidak semuanya menggunakan satuan pengukuran yang sama, maka variabel asal perlu dibakukan 
ke dalam variabel baku. Pembakuan variabel asal $\mathrm{X}$ ke dalam variabel baku Z, dapat dilakukan sebagai berikut :

$$
\begin{gathered}
Z_{1}=\frac{\left(X_{1}-u_{1}\right)}{\sqrt{\sigma_{11}}} \\
Z_{2}=\frac{\left(X_{2}-u_{2}\right)}{\sqrt{\sigma_{22}}} \\
\vdots \\
Z_{p}=\frac{\left(X_{p}-u_{p}\right)}{\sqrt{\sigma_{p p}}}
\end{gathered}
$$

Catatan :

Dalam kasus data contoh (sample), maka kita boleh menduga $u_{1}, u_{2}, \ldots, u_{p}$ dengan $\overline{X_{1}}, \overline{X_{2}}, \ldots, \overline{X_{p}}$ yang merupakan nilai rata-rata contoh serta simpangan baku populasi $\sqrt{\sigma_{i i}}$ dapat diduga berdasarkan simpangan baku contoh $\sqrt{s_{i i}}$ yang merupakan akar pangkat dua dari elemen diagonal utama dalam matriks peragam $S$

Persamaan transformasi z (persamaan 17) dapat dinyatakan secara singkat dalam bentuk matriks berikut :

$$
Z=\left(V^{1 / 2}\right)^{-1}(X-u)
$$

dimana $V^{1 / 2}$ adalah matriks simpangan baku dengan elemen diagonal utama adalah $\left(\sigma_{i i}\right)^{1 / 2}$ sedangkan elemen lainnya adalah nol. Nilai harapan dari variabel $\mathrm{Z}$ adalah nol, $\mathrm{E}(\mathrm{Z})=0$ sedangkan ragamnya adalah :

$$
\operatorname{Cov}(Z)=\left(V^{1 / 2}\right)^{-1} \Sigma\left(V^{1 / 2}\right)^{-1}=\rho
$$

Dengan demikian komponen utama dari $\mathrm{Z}$ dapat ditentukan dari vektor ciri matriks korelasi asal $\rho$. Dalam situasi dimana data pengamatan merupakan contoh (sample) maka matriks korelasi populasi $\rho$ diduga berdasarkan matriks korelasi contoh R. Prosedur analisis serupa dengan menggunakan matriks peragam $\mathrm{S}$ dimana dalam kasus variabel asal tidak mempunyai satuan pengukuran yang sama maka kita menggantikan matriks $\mathrm{S}$ dengan matriks $\mathrm{R}$ sehingga komponen utama diturunkan dari matriks korelasi R.

Dengan demikian dapat dibuatkan suatu pernyataan umum yang berkaitan dengan analisis komponen utama yangditurunkan dari matriks korelasi R sebagai berikut.

Komponen utama ke-j $(j=1,2, \ldots, p)$ daru contoh pengamatan berdimensi p variabel baku (variabel asal yang dibakukan satuan pengukurannya) adalah merupakan kombinasi linear variabel baku yang dinyatakan dalam bentuk berikut

$$
\begin{aligned}
& Y_{j}=a_{1 j} Z_{1}+a_{2 j} Z_{2}+\ldots+a_{p j} Z_{p} \\
& =a_{j}^{\prime} z
\end{aligned}
$$

Vektor $a_{j}^{\prime}$ ditentukan dengan jalan menyelesaikan sisetm persamaan ciri berikut : 


$$
\left(R-\lambda_{j} I\right) a_{j}=0
$$

Agar persamaan (20) menghasilkan solusi vektor $a_{j}$ yang tidak sama dengan nol maka haruslah dipenuhi syarat bahwa determinan dari matriks $\left(R-\lambda_{j} I\right)$ sama dengan nol, jadi haruslah :

$$
\left|R-\lambda_{j} I\right|=0
$$

Ragam dari komponen utama ke-j adalah sama dengan akar ciri ke-j serta antara komponen utama ke-j dan komponen utama ke-i tidak berkorelasi untuk $i \neq j,(i, j=1,2, \ldots, p)$.

Pentingnya suatu komponen utama tertentu, $Y_{j}$, diukur dengan besarnya bagian atau persentase keragaman total yang mampu diterangkan oleh komponen utama ke-j yaitu sebesaar ragam komponen ke-j dibagi dengan ragam total. Untuk komponen utama yang diturunkan dari matriks peragam $\mathrm{S}$, maka ukuran ini tidak lain merupakan rasio akar ciri ke-j, $\lambda_{j}$, dibagi teras matriks $\mathrm{S}$, sebagai berikut :

$$
\text { Peranankomponenutama } Y_{j}=\frac{\lambda_{j}}{\operatorname{tr}(S)}
$$

Apabila komponen utama diturunkan dari matriks korelasi R maka peranan komponen utama ke-j diukur sebagai berikut :

$$
\begin{aligned}
& \text { Peranankomponenutama } Y_{j}=\frac{\lambda_{j}}{\operatorname{tr}(R)}=\frac{\lambda_{j}}{p} \\
& p=\text { banyaknya variabel asal }
\end{aligned}
$$

\section{Catatan :}

Penjumlahan dari semua akar ciri suatu matriks akan sama dengan teras matriks itu. Untuk matriks korelasi berlaku $\operatorname{tr}(\mathrm{R})=\mathrm{p}=$ banyaknya variable asal.

Untuk mengukur keeratan hubungan (korelasi) anatara variabel asal dan komponen utama dapat dilihat melalui besarnya koefisien korelasi antara variabel asal dan komponen utama itu. Untuk komponen utama yang diturunkan dari matriks peragam S maka besarnya koefisien korelasi antara variabel asal ke-i dan komponen utama ke-j dihitung menggunakan persamaan (23) sedangkan apabila komponen utama itu diturunkan dari matriks korelasi $\mathrm{R}$ maka koefisien korelasi antara variabel baku ke-i dan komponen utama ke-j dihitung menggunakan persamaan (24).

$$
\begin{aligned}
& r_{X_{i}} r_{X_{j}}=r_{i j}=\frac{a_{i j} \sqrt{\lambda_{j}}}{s_{i}} \\
& s_{i}=\text { simpangan baku dari variabel } X_{i} \\
& r_{Z_{i}} r_{Y_{j}}=r_{i j}=a_{i j} \sqrt{\lambda_{j}}
\end{aligned}
$$

Variabel baku $Z_{i}$ memiliki nilai simpangan baku, $s_{i}=1$

\section{Penentuan Banyaknya Komponen Utama}

Metode pertama, didasarkan pada kumulatif proporsi keragaman total yang mampu dijelaskan. Metode ini merupakan metode yang paling banyak digunakan, dan bisa diterapkan pada penggunaan matriks korelasi maupun matriks ragam peragam. Minimum persentase kergaman yang mampu dijelaskan ditentukan terlebih dahulu, dan selanjutnya banyaknya komponen yang paling kecil hingga batas itu terpenuhi dijadikan sebagai banyaknya komponen utama yang 
digunakan. Tidak ada patokan baku berapa batas minimum tersebut, sebagian buku menyebutkan $70 \%, 80 \%$, bahkan ada yang $90 \%$. Metode berikutnya hanya bisa diterapkan pada penggunaan matriks korelasi. Ketika menggunakan matriks ini, peubah asal ditransformasi menjadi peubah yang memiliki ragam sama yaitu satu. Pemilihan komponen utama didasarkan pada ragam komponen utama, yang tidak lain adalah akar ciri (nilai iegen). Metode ini disarankan oleh Kaiser (1960) yang berargumen bahwa jika peubah asal saling bebas maka komponen utama tidak lain adalah peubah asal, dan setiap komponen utama akan memiliki ragam satu. Dengan cara ini, komponen yang berpadanan dengan akar ciri kurang dari satu tidak digunakan. Jollife (1972) setelah melakukan studi mengatakan bahwa cut off yang lebih baik adalah 0.7. Metode yang terakhir adalah penggunaan grafik yang disebut plot scree. Cara ini bisa digunakan ketika titik awalnya matriks korelasi maupun ragam peragam. Plot scree merupakan plot antara akar ciri $\lambda_{\mathrm{k}}$ dengan $\mathrm{k}$. Dengan menggunakan metode ini, banyaknya komponen utama yang dipilih, yaitu $\mathrm{k}$, adalah jika pada titik $\mathrm{k}$ tersebut plotnya curam ke kiri tapi tidak curam di kanan. Ide yang ada di belakang metode ini adalah bahwa banyaknya komponen utama yang dipilih sedemikian rupa sehingga selisih antara akar ciri yang berurutan sudah tidak besar lagi. Interpretasi terhadap plot ini sangat subjektif.

\section{ILUSTRASI}

Dalam konteks Provinsi NTT, ada beberapa masalah yang menyebabkan terjadinya kasus human trafficking seperti kemiskinan, penghasilan dari pekerjaan yang ada tidak memadai, keinginan menjadi kaya, persoalan kekurangan informasi, budaya dan pemahaman regulasi dan informasi lain. Masalah-masalah di atas akan menjadi fokus kajian tentang faktor penyebab masalah human trafficking. Faktor-faktor ini dirincikan dalam 37 variabel atau atribut pernyataan mengenai masalah kemiskinan, kurangnya kesadaran/pemahaman, keinginan cepat kaya, rendahnya pendidikan, minimnya kesempatan kerja, kurangnya akses informasi tentang resiko pekerjaan, ekonomi, budaya, migrasi, hukum dan aturan hukum, dan penegak hukum. Faktor-faktor budaya berikut memberikan kontribusi terhadap terjadianya perdagangan orang yaitu peran perempuan dalam keluarga, peran anak dalam keluarga, perkawinan dini, dan sejarah pekerjaan karena hutang (Geradus dkk, 2018). Pernyataan-pernyataan tersebut ditampilkan dalam Tabel 2.1 berikut.

\section{Tabel 7.1 Variabel Penelitian}

\begin{tabular}{|c|c|}
\hline Variabel & Pernyataan \\
\hline $\mathrm{X} 1$ & $\begin{array}{l}\text { Saya menjadi TKW karena saya tidak mengetahui kalau itu ada } \\
\text { bentuk penipuan }\end{array}$ \\
\hline $\mathrm{X} 2$ & $\begin{array}{l}\text { Saya menjadi TKW karena saya tidak tahu TKW biasanya } \\
\text { menjadi budak }\end{array}$ \\
\hline $\mathrm{X} 3$ & Saya menjadi TKW karena saya diajak teman \\
\hline $\mathrm{X} 4$ & $\begin{array}{l}\text { Saya menjadi TKW karena saya tidak mempunyai biaya yang } \\
\text { cukup untuk kehidupan sehari-hari }\end{array}$ \\
\hline $\mathrm{X} 5$ & Saya menjadi TKW karena saya ingin mempunyai banyak uang \\
\hline X6 & Sayamenjadi TKW karena saya merasa miskin \\
\hline
\end{tabular}


X7 Saya menjadi TKW karena saya ingin cepat kaya

X8 Saya menjadi TKW karena saya ingin memiliki barang-barang berharga

X9 Saya menjadi TKW karena saya ingin mempunyai rumah yang mewah

X10 Saya menjadi TKW karena saya mempunyai kehidupan yang tidak layak

X11 Saya menjadi TKW karena saya mempunyai banyak utang

X12 Saya menjadi TKW karena budaya kami mendiskriminasi perempuan

X13 Saya menjadi TKW karena saya perempuan

X14 Saya menjadi TKW karena saya sebagai perempuan dianggap lebih mudah mencari pekerjaan di luar daerah

X15 Saya menjadi TKW karena saya hanya lulusan SD/SMP

X16 Saya menjadi TKW karena pendidikan saya rendah

X17 Saya menjadi TKW karena saya putus sekolah

X18 Saya menjadi TKW karena saya sulit mendapat pekerjaan yang lain

X19 Saya menjadi TKW karenasaya sulit mendapat pekerjaan yang layak

X20 Saya menjadi TKW karena saya hanya bisa menjadi pembantu rumah tangga

X21 Saya menjadi TKW karena saya tidak pernah mendapatkan informasi tentang bahaya/risiko menjadi TKW

X22 Saya menjadi TKW karena saya mendapati nformasi bahwa TKW mendapat gaji yang besar

X23 Saya menjadi TKW karena saya menjadi tulang punggung keluarga dalam mencari nafkah

X24 Saya menjadi TKW karena saya dianggap paling mampu mencar iuang di luar daerah

X25 Saya menjadi TKW karena saya membiayai saudara saya yang sedang sekolah

X26 Saya menjadi TKW karena orang tua ingin saya membangun rumah

X27 Saya menjadi TKW karena saya ingin mempunyai suami orang luar negeri

X28 Saya menjadi TKW karena saya menikah di usia dini dan suami tidak bertanggung jawab

X29 Saya menjadi TKW karena saya gagal dalam berumah tangga

X30 Saya menjadi TKW karena saya mempunyai anak yang membutuhkan biaya

X31 Saya menjadi TKW karena saya ingin keluar dari kampung/daerah saya

X32 Saya menjadi TKW karena saya merasa tidak berkembang tinggal di kampung

X33 Saya menjadi TKW karena saya ditawarkan pekerjaan

X34 Saya menjadi TKW karena saya beranggapan bahwa hukum di Indonesia bisa diatur 
X35 Saya menjadi TKW karena saya merasa aturan hukum Indonesia melindungi saya

X36 Saya menjadi TKW karena penegak hukum di Indonesia bisa membantu saya untuk mendapatkan pekerjaan

X37 Saya menjadi TKW karena saya merasa penegak hukum melindungi saya apabila saya mendapat masalah

Karena banyaknya variabel yang akan diteliti maka akan digunakan suatu metode yang akan menyeleksi variabel-variabel tersebut. Principal component analysis (PCA) dapat digunakan untuk menghindari kasus multikolinieritas. Tentukan banyaknya komponen utama yang bisa digunakan untuk analisis lanjut!

Jawab :

Dengan menggunakan software Minitab, diperoleh hasil sebagai berikut :

Principal Component Analysis: X1, X2, X3, X4, X5, X6, X7, X8, X9, X10, X11, $\mathrm{X} 12, \ldots, \mathrm{X} 37$

\begin{tabular}{|c|c|c|c|c|c|c|c|c|c|}
\hline Eigenvalue & 11.898 & 3.910 & 2.970 & 2.518 & 2.293 & 1.695 & 1.402 & $02 \quad 1.241$ & 1.184 \\
\hline Proportion & 0.322 & 20.106 & 0.080 & 0.068 & 0.062 & 0.046 & $0.03 \varepsilon$ & $\begin{array}{ll}38 & 0.034\end{array}$ & 0.032 \\
\hline Cumulative & 0.322 & 20.427 & 0.508 & 0.576 & 0.638 & 0.683 & 0.721 & 210.755 & 0.787 \\
\hline igenvalue & 0.971 & 0.819 & 0.780 & 0.699 & 0.647 & 0.538 & 0.513 & 130.400 & 0.378 \\
\hline roportion & 0.026 & 0.022 & 0.021 & 0.019 & 0.017 & 0.015 & 0.014 & $14 \quad 0.011$ & 0.010 \\
\hline Cumulative & 0.813 & 0.835 & 0.856 & 0.875 & 0.893 & 0.907 & 0.921 & 0.932 & 0.942 \\
\hline igenvalue & 0.323 & 0.292 & 0.238 & 0.228 & 0.169 & 0.164 & 0.134 & $34 \quad 0.119$ & 0.099 \\
\hline roportion & 0.009 & 0.008 & 0.006 & 0.006 & 0.005 & 0.004 & 0.004 & $04 \quad 0.003$ & 0.003 \\
\hline Cumulative & 0.951 & 0.959 & 0.965 & 0.971 & 0.976 & 0.980 & 0.984 & $84 \quad 0.987$ & 0.990 \\
\hline igenvalue & 0.089 & 0.079 & 0.051 & 0.038 & 0.035 & 0.033 & 0.027 & $27 \quad 0.012$ & 0.008 \\
\hline Proportion & 0.002 & 0.002 & 0.001 & 0.001 & 0.001 & 0.001 & 0.001 & 010.000 & 0.000 \\
\hline Cumulative & 0.992 & 0.994 & 0.996 & 0.997 & 0.998 & 0.999 & \multicolumn{2}{|c|}{0.999} & 1.000 \\
\hline Eigenvalue & 0.004 & & & & & & & & \\
\hline Proportion & 0.000 & & & & & & & & \\
\hline Cumulative & 1.000 & & & & & & & & \\
\hline Variable & $\mathrm{PC} 1$ & $\mathrm{PC} 2$ & $\mathrm{PC} 3$ & PC 4 & PC5 & & PC 6 & PC7 & PC 8 \\
\hline $\mathrm{X} 1$ & 0.129 & -0.124 & -0.192 & -0.139 & 0.418 & & 123 & -0.008 & 0.009 \\
\hline$x 2$ & 0.151 & -0.068 & -0.150 & -0.142 & 0.411 & -0 & .012 & -0.158 & 0.116 \\
\hline X3 & 0.187 & -0.083 & -0.206 & -0.084 & -0.014 & -0 & .084 & -0.147 & -0.014 \\
\hline X4 & 0.155 & -0.165 & -0.138 & -0.253 & -0.090 & & .044 & 0.114 & -0.233 \\
\hline X5 & 0.171 & -0.078 & -0.229 & -0.127 & 0.010 & & 224 & -0.139 & -0.130 \\
\hline$x 6$ & 0.163 & -0.195 & -0.286 & -0.025 & -0.018 & & .048 & 0.244 & 0.010 \\
\hline X7 & 0.204 & -0.101 & -0.178 & 0.051 & -0.068 & & 130 & 0.193 & 0.242 \\
\hline X8 & 0.120 & -0.060 & -0.193 & 0.266 & 0.119 & & 339 & 0.109 & -0.217 \\
\hline X9 & 0.174 & -0.063 & -0.213 & 0.144 & -0.137 & & .092 & -0.203 & 0.090 \\
\hline $\mathrm{X} 10$ & 0.204 & -0.002 & -0.122 & -0.006 & -0.043 & & .077 & 0.108 & 0.303 \\
\hline$X 11$ & 0.195 & -0.195 & -0.023 & 0.078 & -0.055 & & 118 & 0.159 & 0.032 \\
\hline $\mathrm{X} 12$ & 0.192 & 0.069 & -0.119 & 0.273 & 0.159 & & 049 & 0.055 & -0.091 \\
\hline$X 13$ & 0.164 & -0.052 & -0.102 & 0.184 & -0.162 & & 123 & -0.055 & 0.058 \\
\hline X14 & 0.197 & -0.073 & -0.114 & -0.104 & -0.077 & & .087 & -0.168 & 0.069 \\
\hline X15 & 0.197 & -0.108 & 0.103 & -0.096 & -0.087 & & 139 & 0.371 & 0.033 \\
\hline X16 & 0.165 & -0.113 & 0.240 & -0.168 & -0.137 & & 151 & 0.321 & -0.191 \\
\hline X17 & 0.195 & 0.015 & 0.267 & -0.013 & 0.044 & & 141 & 0.267 & 0.010 \\
\hline X18 & 0.176 & 0.049 & 0.231 & -0.108 & 0.005 & & 221 & -0.162 & 0.033 \\
\hline X19 & 0.202 & 0.065 & 0.111 & -0.193 & 0.152 & & 172 & 0.060 & 0.113 \\
\hline
\end{tabular}




\begin{tabular}{|c|c|c|c|c|c|c|c|c|}
\hline $\mathrm{x} 20$ & 0.167 & 0.058 & 0.162 & 0.131 & 0.015 & 0.263 & 0.057 & -0.230 \\
\hline X21 & 0.130 & 0.046 & 0.072 & -0.218 & 0.345 & -0.215 & -0.019 & -0.082 \\
\hline X22 & 0.143 & 0.012 & 0.237 & -0.314 & 0.120 & -0.038 & -0.281 & -0.091 \\
\hline X23 & 0.223 & 0.032 & 0.069 & 0.004 & -0.143 & -0.002 & -0.231 & 0.077 \\
\hline X24 & 0.213 & -0.027 & 0.091 & -0.078 & -0.213 & -0.073 & -0.317 & 0.111 \\
\hline X25 & 0.215 & -0.090 & 0.066 & 0.006 & -0.223 & -0.141 & -0.108 & 0.065 \\
\hline X26 & 0.183 & -0.045 & 0.107 & 0.038 & -0.250 & 0.159 & -0.143 & -0.363 \\
\hline X27 & 0.093 & 0.193 & -0.095 & 0.321 & 0.100 & -0.122 & -0.149 & -0.050 \\
\hline X28 & 0.183 & 0.139 & 0.074 & 0.290 & 0.174 & -0.189 & -0.042 & -0.058 \\
\hline X29 & 0.204 & 0.155 & 0.144 & 0.215 & 0.074 & -0.191 & -0.047 & -0.078 \\
\hline 30 & 0.175 & 0.013 & 0.184 & 0.190 & 0.148 & -0.153 & 0.072 & -0.270 \\
\hline X31 & 0.122 & 0.299 & 0.084 & 0.027 & 0.006 & 0.184 & 0.114 & 0.303 \\
\hline X32 & 0.128 & 0.221 & 0.099 & 0.070 & -0.067 & -0.236 & 084 & 0.370 \\
\hline X33 & 0.070 & 0.277 & 0.055 & -0.191 & -0.008 & 0.408 & -0.012 & 034 \\
\hline X34 & 0.063 & 0.416 & -0.159 & -0.117 & 0.140 & 0.027 & & 53 \\
\hline$\times 35$ & -0.018 & 0.279 & -0.276 & -0.187 & -0 & -0.1 & & -0.266 \\
\hline$\times 36$ & 0.069 & 0 . & -0.183 & -0.048 & -0 & -0 . & -0 . & -0.169 \\
\hline$\times 37$ & 0.048 & 0.321 & -0.179 & -0.181 & -0.152 & -0.168 & 0.137 & -0.032 \\
\hline Var: & PC 9 & & $\mathrm{PC} 11$ & $\mathrm{PC} 12$ & $\mathrm{PC} 13$ & PC14 & PC15 & PC1 6 \\
\hline X1 & 0.071 & -0.098 & -0.241 & 0.076 & -0.117 & 0.004 & 0.100 & 0.072 \\
\hline $\mathrm{x} 2$ & -0.061 & -0.207 & -0.102 & 0.132 & -0.087 & 0.072 & 0.098 & -0.141 \\
\hline X3 & 0.177 & -0.006 & -0.159 & -0.187 & -0.228 & 0.485 & -0.039 & 213 \\
\hline X4 & 0.028 & 0 & -0.089 & -0.184 & 0.235 & -0.020 & 0.229 & -0.228 \\
\hline$x 5$ & 0.131 & 0. & 0.069 & -0.080 & .71 & 0.195 & -0.223 & 402 \\
\hline x6 & -0.171 & 0.048 & 0.158 & 0.030 & -0 . & 0.141 & -0.298 & 0.164 \\
\hline$\times 7$ & -0.287 & 0 . & 0.006 & 15 & -0 . & 0 . & -0.227 & 0.111 \\
\hline$x 8$ & 0.147 & 0 . & 0.040 & -0.232 & -0 . & -0.299 & 0.025 & -0.172 \\
\hline X9 & 27 & -0 . & -0.189 & 0.123 & 24 & -0 . & 0.351 & 93 \\
\hline $\mathrm{X} 10$ & -0.271 & 0 & -0.062 & -0.114 & -0 . & -0 . & 0.117 & 057 \\
\hline $\mathrm{X} 11$ & 0.050 & 0 . & -0.379 & & -0 . & -0 . & -0.051 & -0.105 \\
\hline $\mathrm{X} 12$ & 0.181 & -0 & 0.096 & 09 & 97 & -0 . & -0.148 & -0.155 \\
\hline $\mathrm{x} 13$ & 0.360 & 0 . & 0.341 & 20 & -0 . & -0 . & 0 . & \\
\hline X14 & 83 & -0 . & 0.197 & 77 & -0 & -0 . & 0.061 & 140 \\
\hline X15 & 0.141 & -0 & 0.146 & -0 . & -0 . & -0 . & 0.063 & -0 \\
\hline X16 & 0.106 & -0 . & 0.101 & -0 . & -0 & -0.066 & -0.073 & -0.049 \\
\hline $\mathrm{X} 17$ & -0.025 & 0 . & -0.105 & 26 & -0 . & 0 & 0.421 & 226 \\
\hline X18 & 0.029 & -0 . & -0.193 & -0 . & -0 . & -0.243 & -0.374 & 158 \\
\hline X19 & -0.186 & -0 & 0.305 & 0 . & 6 & 0 . & 0.161 & -0 \\
\hline X20 & -0.012 & -0 & -0.128 & 09 & 7 & 0.212 & -0.089 & -0 \\
\hline X21 & -0.001 & 0. & 0.245 & -0.206 & 4 & -0.240 & -0.149 & -0.084 \\
\hline$\times 22$ & 0.147 & 0. & -0.095 & -0.092 & & -0.166 & -0.077 & 228 \\
\hline X23 & -0.337 & 0. & 0.042 & -0.147 & & 0. & -0.009 & -0.162 \\
\hline X24 & -0.150 & -0 & 0.041 & 0. & & -0 & 33 & 203 \\
\hline X25 & -0.106 & -0 & 0.102 & -0 . & & 0 . & 0.023 & -0.030 \\
\hline x26 & 0.041 & -0 & -0.008 & -0.135 & -0 . & -0 & 61 & 99 \\
\hline X27 & 0.005 & -0 & 0.113 & -0 . & -0 . & 0 . & 0.231 & 07 \\
\hline X28 & -0.157 & 0. & 0.178 & & & 0 . & -0.156 & -0.100 \\
\hline X29 & -0.109 & 0. & 0.011 & 18 & -0 . & 0 . & -0.068 & 169 \\
\hline 30 & -0.157 & 0.2 & -0.230 & 0 . & -0 . & 0 . & 0.089 & 040 \\
\hline X31 & 0.251 & -0.0 & -0.163 & 0 . & 1 & 0. & -0.107 & -0.303 \\
\hline X32 & 0.287 & 0.1 & -0.125 & -0.248 & 6 & 0. & -0.034 & 0.183 \\
\hline$\times 33$ & 0.079 & 0.2 & 0.191 & -0.002 & -0 & 0.242 & 0.163 & -0.083 \\
\hline X34 & -0.022 & 0.0 & 0.065 & 0 . & 0 . & -0.092 & 0.090 & 0.128 \\
\hline X35 & -0.191 & 0.0 & 0.045 & 0.219 & -0 . & 0. & 0.085 & 0.039 \\
\hline X36 & -0.030 & 0.029 & -0.212 & -0.074 & -0.133 & -0.187 & -0.157 & -0.246 \\
\hline X37 & 0.023 & -0.315 & -0.141 & 0.022 & 0.253 & -0.001 & -0.051 & 0.19 \\
\hline Varia & PC1 7 & & PC19 & $\mathrm{PC} 20$ & & $\mathrm{PC} 22$ & PC23 & C2 4 \\
\hline $\mathrm{X} 1$ & 0.152 & -0.051 & -0.049 & 0.080 & -0.169 & 0.017 & 0.284 & -0.207 \\
\hline $\mathrm{x} 2$ & -0.019 & 0.171 & -0.015 & -0.245 & 0.086 & 0.123 & 0.146 & 0.146 \\
\hline X3 & 0.036 & -0.247 & -0.256 & 0.021 & -0.078 & 0.089 & -0.215 & 0.080 \\
\hline $\mathrm{X} 4$ & 0.250 & 0.191 & 0.118 & 0.067 & 0.220 & -0.060 & -0.090 & 0.029 \\
\hline X5 & 0.031 & 0.421 & 0.209 & 0.175 & -0.134 & 0.054 & 0.126 & -0.071 \\
\hline X6 & -0.003 & -0.183 & 0.035 & -0.147 & 0.244 & -0.264 & -0.118 & 0.12 \\
\hline
\end{tabular}




\begin{tabular}{|c|c|c|c|c|c|c|c|c|}
\hline$\times 7$ & -0.061 & 0.146 & -0.113 & -0.134 & -0.030 & 0.010 & -0.161 & -0.159 \\
\hline $\mathrm{x} 8$ & -0.223 & 0.153 & -0.151 & -0.079 & -0.257 & -0.252 & 0.050 & 0.048 \\
\hline$\times 9$ & -0.220 & -0.185 & -0.050 & 0.229 & -0.200 & 0.103 & -0.148 & -0.038 \\
\hline X10 & 0.302 & -0.136 & -0.109 & 0.070 & 0.104 & 0.081 & 0.049 & 0.079 \\
\hline X11 & -0.391 & -0.140 & 0.407 & -0.306 & -0.052 & 0.125 & 0.009 & -0.130 \\
\hline $\mathrm{X} 12$ & 0.154 & -0.231 & 0.272 & 0.314 & 0.305 & 0.156 & 0.259 & 0.210 \\
\hline X13 & 0.247 & -0.124 & -0.203 & -0.331 & -0.153 & 0.093 & 0.126 & 0.154 \\
\hline X14 & -0.176 & 0.146 & -0.025 & 0.268 & 0.156 & -0.259 & -0.218 & -0.101 \\
\hline X15 & 0.108 & -0.023 & 0.028 & 0.141 & 0.040 & 0.050 & 0.033 & -0.258 \\
\hline X16 & -0.021 & 0.111 & -0.028 & 0.066 & -0.370 & 0.018 & 0.066 & 0.030 \\
\hline $\mathrm{X} 17$ & -0.000 & 0.006 & 0.148 & -0.089 & -0.022 & -0.082 & 0.113 & 0.296 \\
\hline 18 & -0.015 & -0.110 & 0.016 & 0.197 & -0.106 & 0.090 & -0.138 & 0.275 \\
\hline 19 & -0.194 & -0.090 & 0.013 & 0.071 & 0.084 & -0.059 & -0.063 & -0.165 \\
\hline $\mathrm{x} 20$ & 0.356 & -0.268 & 0.020 & -0.096 & -0.168 & -0.163 & -0.234 & -0.127 \\
\hline X21 & -0.195 & -0.211 & -0.070 & -0.058 & -0.109 & 0.077 & -0.219 & 0.088 \\
\hline $\mathrm{x} 22$ & 0.128 & -0.081 & 0.060 & -0.244 & 0.124 & -0.257 & 0.008 & -0.040 \\
\hline X23 & 0.018 & -0.065 & -0.055 & 0.235 & -0.123 & -0.266 & 0.330 & -0.014 \\
\hline X24 & 0.059 & 0.100 & 0.107 & -0.198 & -0.042 & -0.088 & 0.007 & -0.033 \\
\hline X25 & 0.086 & 0.188 & 0.018 & -0.055 & -0.143 & 0.381 & -0.075 & 0.224 \\
\hline X26 & -0.272 & -0.085 & -0.217 & -0.145 & 0.489 & 0.224 & 0.148 & -0.101 \\
\hline X27 & 0.126 & 0.061 & 0.238 & -0.187 & -0.012 & -0.269 & -0.255 & -0.059 \\
\hline X28 & -0.151 & 0.007 & -0.049 & -0.035 & -0.090 & 0.049 & 0.246 & -0.062 \\
\hline X29 & 0.037 & 0.216 & 0.158 & 0.007 & 0.104 & 0.101 & -0.049 & -0.174 \\
\hline 30 & -0.015 & 0.179 & -0.383 & 0.201 & 0.074 & -0.074 & -0.162 & 0.094 \\
\hline X31 & -0.026 & 0.339 & -0.080 & -0.125 & 0.130 & -0.060 & -0.040 & 0.272 \\
\hline 32 & -0.137 & -0.095 & 0.069 & 0.187 & 0.058 & -0.161 & -0.018 & -0.072 \\
\hline 33 & -0.077 & -0.146 & 0.080 & -0.058 & -0.129 & 0.106 & 0.132 & -0.152 \\
\hline 34 & 0.038 & 0.066 & -0.088 & -0.013 & 0.029 & 0.353 & -0.281 & -0.120 \\
\hline 35 & -0.179 & -0.086 & 0.258 & 0.063 & -0.111 & -0.101 & -0.021 & 0.442 \\
\hline 36 & 0.167 & -0.008 & 0.092 & -0.038 & -0.078 & 0.059 & 0.031 & -0.273 \\
\hline X37 & -0.082 & -0.016 & -0.341 & -0.137 & 0.031 & -0.202 & 0.312 & -0.011 \\
\hline Var & PC2 5 & PC2 6 & $\mathrm{PC} 27$ & $\mathrm{PC} 28$ & 29 & & 1 & C32 \\
\hline $\mathrm{X} 1$ & 0.207 & -0.224 & -0.181 & -0.030 & -0.303 & -0.392 & 0.015 & 0.104 \\
\hline $\mathrm{x} 2$ & 0.002 & -0.091 & 0.274 & -0.003 & 0.222 & 0.367 & -0.210 & 0.035 \\
\hline X3 & -0.194 & 0.171 & -0.131 & 0.049 & 0.206 & 0.054 & 0.252 & -0.073 \\
\hline $\mathrm{X} 4$ & 0.084 & -0.150 & -0.090 & -0.251 & 0.275 & -0.107 & -0.160 & -0.065 \\
\hline$x 5$ & 0.114 & 0.203 & 0.107 & 0.066 & 0.103 & 0.071 & 0.193 & 0.003 \\
\hline$x 6$ & -0.078 & -0.149 & -0.121 & 0.195 & -0.095 & 0.065 & -0.168 & 0.188 \\
\hline X7 & -0.215 & -0.178 & 0.011 & -0.408 & -0.138 & -0.124 & 0.074 & -0.156 \\
\hline X8 & -0.061 & 0.093 & 0.075 & 0.225 & -0.027 & 0.006 & -0.042 & 0.101 \\
\hline X9 & -0.236 & -0.300 & -0.194 & 0.080 & 0.099 & 0.128 & -0.066 & -0.023 \\
\hline $\mathrm{X} 10$ & 0.236 & 0.323 & -0.033 & 0.225 & 0.199 & -0.030 & -0.116 & -0.010 \\
\hline X11 & 0.173 & 0.190 & 0.155 & 0.031 & -0.051 & -0.000 & 0.050 & -0.076 \\
\hline X12 & -0.346 & -0.005 & 0.198 & -0.074 & -0.128 & -0.118 & 0.010 & -0.169 \\
\hline X13 & 0.197 & -0.116 & 0.111 & -0.036 & 0.018 & -0.007 & 0.185 & -0.161 \\
\hline X14 & 0.110 & 0.339 & -0.115 & -0.193 & -0.193 & 0.016 & -0.185 & -0.006 \\
\hline X15 & -0.053 & -0.096 & -0.014 & 0.157 & -0.002 & 0.379 & 0.136 & 0.303 \\
\hline X16 & -0.133 & -0.190 & 0.061 & -0.003 & 0.223 & -0.148 & -0.122 & -0.078 \\
\hline X17 & -0.162 & 0.286 & -0.191 & -0.297 & -0.122 & 0.115 & 0.213 & 0.003 \\
\hline $\mathrm{X} 18$ & 0.130 & -0.068 & -0.020 & -0.189 & 0.183 & -0.045 & -0.093 & 0.001 \\
\hline X19 & 0.110 & 0.019 & 0.048 & 0.304 & 0.133 & -0.305 & 0.261 & -0.393 \\
\hline $\mathrm{x} 20$ & 0.242 & 0.071 & 0.098 & -0.038 & 0.015 & 0.016 & -0.117 & 0.098 \\
\hline X21 & 0.135 & -0.007 & 0.011 & -0.202 & -0.146 & 0.209 & 0.038 & -0.106 \\
\hline $\mathrm{x} 22$ & -0.329 & 0.013 & -0.164 & 0.263 & -0.124 & -0.013 & 0.041 & 0.038 \\
\hline $\mathrm{x} 23$ & 0.164 & -0.147 & 0.110 & -0.153 & -0.178 & 0.310 & 0.230 & 0.102 \\
\hline X24 & -0.301 & 0.005 & 0.314 & -0.001 & 0.098 & -0.287 & 0.087 & 0.242 \\
\hline X25 & 0.032 & 0.135 & -0.094 & 0.200 & -0.444 & -0.079 & -0.313 & 0.005 \\
\hline $\mathrm{x} 26$ & 0.238 & -0.143 & -0.020 & -0.083 & -0.006 & -0.082 & 0.051 & 0.149 \\
\hline X27 & 0.084 & -0.093 & 0.020 & -0.156 & 0.036 & -0.044 & -0.056 & -0.048 \\
\hline $\mathrm{x} 28$ & -0.055 & 0.211 & -0.438 & -0.095 & 0.327 & -0.160 & -0.101 & 0.295 \\
\hline X29 & 0.004 & -0.171 & -0.180 & 0.162 & 0.121 & 0.242 & -0.068 & -0.306 \\
\hline 30 & -0.052 & 0.013 & 0.301 & 0.171 & -0.178 & -0.044 & -0.041 & -0.081 \\
\hline X31 & 0.136 & -0.263 & -0.255 & 0.113 & -0.068 & -0.029 & 0.184 & 0.032 \\
\hline X32 & 0.110 & -0.070 & 0.264 & 0.046 & 0.089 & -0.114 & -0.148 & 0.178 \\
\hline
\end{tabular}




\begin{tabular}{|c|c|c|c|c|c|c|c|c|}
\hline$\times 33$ & -0.082 & -0.098 & 0.029 & -0.013 & -0.103 & 0.057 & -0.451 & -0.041 \\
\hline$\times 34$ & -0.106 & 0.076 & 0.178 & -0.088 & -0.031 & -0.061 & 0.176 & 0.396 \\
\hline$\times 35$ & 0.153 & -0.139 & -0.010 & 0.145 & 0.003 & -0.086 & 0.089 & 0.103 \\
\hline$\times 36$ & -0.036 & 0.069 & -0.130 & 0.058 & -0.148 & 0.122 & 0.101 & -0.180 \\
\hline$\times 37$ & -0.096 & 0.181 & 0.085 & -0.116 & 0.055 & 0.026 & -0.211 & -0.242 \\
\hline Variable & PC33 & PC 34 & PC35 & PC 36 & PC37 & & & \\
\hline $\mathrm{X} 1$ & -0.086 & 0.126 & 0.009 & -0.144 & 0.004 & & & \\
\hline $\mathrm{x} 2$ & -0.145 & -0.081 & 0.047 & 0.302 & -0.133 & & & \\
\hline x3 & -0.098 & 0.060 & -0.102 & -0.145 & 0.120 & & & \\
\hline $\mathrm{X} 4$ & 0.211 & 0.205 & 0.023 & 0.120 & 0.094 & & & \\
\hline X5 & -0.003 & -0.172 & 0.152 & -0.155 & -0.054 & & & \\
\hline $\mathrm{x} 6$ & 0.062 & 0.182 & 0.014 & -0.126 & -0.413 & & & \\
\hline $\mathrm{X} 7$ & -0.133 & -0.194 & 0.060 & 0.224 & 0.336 & & & \\
\hline $\mathrm{x} 8$ & -0.134 & 0.297 & -0.097 & 0.102 & 0.209 & & & \\
\hline$\times 9$ & 0.056 & -0.125 & 0.050 & 0.005 & -0.145 & & & \\
\hline $\mathrm{X} 10$ & -0.144 & -0.260 & -0.075 & -0.174 & 0.076 & & & \\
\hline $\mathrm{X} 11$ & 0.316 & -0.070 & -0.136 & -0.067 & 0.013 & & & \\
\hline $\mathrm{X} 12$ & -0.004 & -0.108 & -0.086 & -0.012 & 0.045 & & & \\
\hline $\mathrm{x} 13$ & 0.170 & 0.084 & 0.089 & 0.153 & -0.039 & & & \\
\hline X14 & -0.048 & -0.074 & -0.119 & 0.057 & -0.064 & & & \\
\hline X15 & 0.160 & -0.016 & 0.281 & -0.047 & 0.317 & & & \\
\hline X16 & -0.178 & -0.296 & -0.313 & -0.034 & -0.315 & & & \\
\hline $\mathrm{X} 17$ & -0.195 & 0.172 & 0.104 & 0.003 & -0.159 & & & \\
\hline $\mathrm{X} 18$ & 0.259 & 0.283 & 0.127 & 0.050 & 0.024 & & & \\
\hline X19 & 0.108 & 0.117 & 0.050 & 0.208 & -0.095 & & & \\
\hline X20 & -0.163 & -0.103 & -0.078 & 0.083 & 0.083 & & & \\
\hline X21 & -0.186 & -0.045 & 0.168 & -0.258 & 0.008 & & & \\
\hline $\mathrm{x} 22$ & 0.104 & -0.224 & -0.148 & 0.261 & 0.172 & & & \\
\hline $\mathrm{x} 23$ & 0.169 & 0.022 & -0.334 & 0.055 & -0.067 & & & \\
\hline X24 & -0.143 & 0.192 & 0.198 & -0.365 & -0.007 & & & \\
\hline X25 & 0.024 & 0.106 & -0.051 & 0.157 & 0.051 & & & \\
\hline X26 & -0.252 & -0.104 & -0.004 & -0.029 & -0.013 & & & \\
\hline X27 & 0.149 & -0.205 & 0.018 & -0.162 & -0.061 & & & \\
\hline X28 & 0.165 & -0.103 & 0.157 & 0.152 & -0.006 & & & \\
\hline X29 & -0.216 & 0.355 & -0.267 & -0.194 & 0.181 & & & \\
\hline 30 & 0.234 & -0.140 & 0.292 & -0.054 & -0.063 & & & \\
\hline X31 & 0.066 & -0.197 & -0.036 & -0.199 & -0.038 & & & \\
\hline$\times 32$ & -0.296 & 0.136 & 0.093 & 0.249 & -0.005 & & & \\
\hline X33 & 0.129 & -0.056 & 0.120 & -0.212 & 0.100 & & & \\
\hline$\times 34$ & 0.181 & 0.116 & -0.389 & 0.069 & -0.130 & & & \\
\hline$\times 35$ & -0.128 & -0.126 & 0.067 & 0.100 & 0.324 & & & \\
\hline$\times 36$ & -0.162 & 0.047 & 0.333 & 0.237 & -0.362 & & & \\
\hline$\times 37$ & 0.168 & 0.092 & -0.072 & -0.177 & 0.104 & & & \\
\hline
\end{tabular}

Secara ringkas dapat disajikan dalam Tabel 7.2:

Tabel 7.2 Nilai Komponen Utama dan Varians

\begin{tabular}{|l|c|c|c|c|c|c|}
\hline \multicolumn{1}{|c|}{ Variabel } & \multicolumn{7}{c|}{$\mathrm{Y}_{\mathrm{j}}$} \\
\hline & 1 & 2 & $\ldots$ & 9 & $\ldots$ & 37 \\
\hline $\mathrm{X}_{1}$ & 0.129 & -0.124 & $\ldots$ & 0.071 & $\ldots$ & 0.004 \\
\hline $\mathrm{X}_{2}$ & 0.151 & -0.068 & $\ldots$ & -0.061 & $\ldots$ & -0.133 \\
\hline$\ldots$ & $\ldots$ & $\ldots$ & $\ldots$ & $\ldots$ & $\ldots$ & $\ldots$ \\
\hline $\mathrm{X}_{37}$ & 0.048 & 0.321 & $\ldots$ & 0.023 & $\ldots$ & 0.104 \\
\hline Nilai eigen & 11.898 & 3.910 & $\ldots$ & 1.184 & $\ldots$ & 0.004 \\
\hline Total varians (\%) & 32,2 & 10,6 & $\ldots$ & 3.2 & $\ldots$ & 0 \\
\hline Varians komulatif (\%) & 32.2 & 42.8 & $\ldots$ & 78.7 & $\ldots$ & 100 \\
\hline
\end{tabular}


Dari Tabel 7.2 diperoleh Persamaan Komponen Utama sebagai berikut :

$$
\begin{aligned}
& \mathrm{Y}_{1}=0.129 \mathrm{X}_{1}+0.151 \mathrm{X}_{2}+\ldots+0.071 \mathrm{X}_{9}+\ldots+0.004 \mathrm{X}_{37} \\
& \mathrm{Y}_{2}=0.151 \mathrm{X}_{1}-0.068 \mathrm{X}_{2}+\ldots-0.061 \mathrm{X}_{9}+\ldots-0.133 \mathrm{X}_{37} \\
& \cdot \\
& \cdot \\
& \mathrm{Y}_{37}=0.048 \mathrm{X}_{1}+0.321 \mathrm{X}_{2}+\ldots+0.023 \mathrm{X}_{9}+\ldots+0.104 \mathrm{X}_{37}
\end{aligned}
$$

Hasil penelitian human trafficking menunjukkan nilai eigen untuk komponen utama pertama $\left(\mathrm{PC}_{1}\right)$, ke dua $\left(\mathrm{PC}_{2}\right)$ sampai ke sembilan $\left(\mathrm{PC}_{9}\right)$ adalah

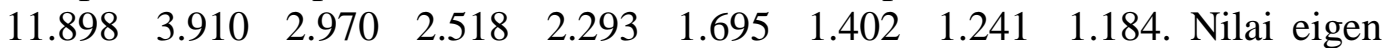

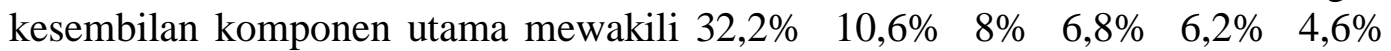
$3,8 \% \quad 3,4 \% 3,2 \%$ dari seluruh variabilitas (keragaman). Bila diakumulasikan, kesembilan komponen utama menyatakan $78,7 \%$ dari total variabilitas. Ini berarti jika 37 variabel direduksi menjadi sembilan variabel, maka kesembilan variabel baru dapat menjelaskan $78,7 \%$ dari total variabilitas ke 37 variabel asal dengan tidak mengurangi informasi awal dari ke 37 variabel. Berdasarkan keragaman total yang diperoleh, maka banyaknya komponen utama yang dipilih untuk tujuan analisis lanjut adalah sembilan komponen utama, karena memiliki keragaman total yang cukup tinggi yaitu mencapai $78,7 \%$ dengan kriteria pemilihan batas nilai eigen lebih besar dari satu

Untuk tujuan analisis selanjutnya yaitu untuk Analisis Faktor, maka perlu dihitung nilai faktor loading berdasarkan nilai eigen dan nilai bobot komponen utama, dan banyaknya faktor yang akan digunakan dalam analisis faktor ada sebanyak sembilan faktor sesuai hasil banyaknya komponen utama dengan tidak mengurangi informasi dari 37 variabel asal yang digunakan.

\section{LATIHAN}

1. Peubah Acak $X_{1}, X_{2}, X_{3}$ mempunyai matriks kovarian sebagai berikut :

$$
\sum=\left[\begin{array}{ccc}
1 & -2 & 0 \\
-2 & 5 & 0 \\
0 & 0 & 2
\end{array}\right]
$$

Tentukan banyaknya komponen utama yang diperoleh!

2. Kovariance Matriks

$$
\Sigma=\left[\begin{array}{cc}
1 & 4 \\
4 & 100
\end{array}\right] \text { maka } \boldsymbol{P}=\left[\begin{array}{cc}
1 & 0.4 \\
0.4 & 1
\end{array}\right]
$$

Tentukan banyaknya komponen utama yang diperoleh! 


\section{BAB VIII \\ ANALISIS FAKTOR (FACTOR ANALYSIS)}

\subsection{PENGANTAR}

Analisis faktor adalah salah satu analisis yang banyak digunakan pada statistik peubah ganda (multivariat), diperkenalkan pertama kali oleh Sperman (1904) dan dikembangkan oleh Thurstone (1947), Thomson (1951), Lawley (1940, 1941) dan lainnya. Pada awalnya analisis ini tergolong kontroversial, namun dalam perkembangannya dirasakan menjadi alat yang sangat berguna, terutama setelah perkembangan komputer dan paket-paket perangkat lunak statistik

Di dalam analisis varian, analisis regresi, dan analisis diskriminan, satu variabel merupakan variabel tak bebas. Di dalam analisis faktor, variabel tidak dikelompokkan menjadi variabel bebas (independent variable) dan tak bebas (dependent variable), sebagai penggantinya seluruk kumpulan variabel dianggap terjadi hubungan interdependensi. Teknik interdependensi bertujuan untuk memberikan arti kepada suatu kumpulan variabel atau mengelompokkan (mereduksi) suatu kumpulan variabel yang jumlahnya banyak menjadi kelompok variabel baru yang jumlahnya lebih sedikit tetapi tidak mengurangi informasi yang terkandung di dalam variabel aslinya.

Tujuan utama dari analisis faktor adalah untuk menguraikan hubunganhubungan kovarians di antara banyak variabel-variabel yang berkaitan (multikorelasi) dengan menggunakan beberapa istilah dasar yang disebut Faktor. Pada dasarnya, model faktor termotivasi oleh argumentasi berikut: diumpamakan bahwa variabel-variabel dapat dikelompokkan menurut hubungan atau korelasi antar variabel. Misalkan semua variabel di dalam kelompok tertentu saling bekorelasi satu sama lain, tetapi mempunyai korelasi-korelasi yang relatif kecil dengan variabel-variabel di suatu kelompok yang berbeda. Maka dapat diasumsikan bahwa kelompok tersebut dapat mewakili variabel-variabel yang saling berkorelasi dan membangun sebuah faktor yang bertanggung jawab dalam pengamatan hubungan antar variabel tersebut.

Dalam bab ini Anda akan mempelajari analisis faktor yang mencakup materi-materi bahasan sebagai berikut : Konsep Dasar Analisis Faktor, Model Faktor, Metode Pendugaan dalam Analisis Faktor, dan Rotasi Faktor.

\subsection{URAIAN}

\section{A. Konsep Dasar Analisis Faktor}

Analisis Faktor merupakan suatu teknik analisis statistika yang digunakan untuk meneliti keterkaitan (interrelationships) peubah-peubah dalam suatu kumpulan data. Dengan kata lain, analisis faktor merupakan salah satu teknik untuk menyederhanakan kumpulan peubah (variabel) yang banyak dan saling berkorelasi menjadi suatu kumpulan peubah baru yang ringkas dan tidak saling berkorelasi yang disebut faktor. Analisis faktor bertujuan untuk mempelajari beberapa sifat yang mendasar namun tidak terobservasi kuantitasnya. 
Analisis Faktor mempunyai karakter khusus yaitu mampu untuk mengurai data. Jika terdapat korelasi dari suatu kumpulan peubah, maka analisis faktor akan memperlihatkan beberapa pola yang mendasari sehingga peubah yang ada dapat dirancang atau dikurangi menjadi suatu kumpulan faktor atau komponen yang lebih kecil.

Analisis Faktor ini dilakukan untuk memperoleh sejumlah kecil faktor yang mempunyai sifat-sifat sebagai berikut:

a. Mampu menerangkan keragaman data secara maksimal.

b. Terdapatnya kebebasan faktor.

c. Tiap faktor dapat dijelaskan dengan sejelas-jelasnya.

Langkah-langkah yang diperlukan di dalam analisis faktor adalah diawali dengan merumuskan masalah, kemudian bentuk matriks korelasi, lalu tentukan metode analisis faktor, selanjutnya lakukan rotasi, dan yang terakhir adalah interpretasikan faktor yang dihasilkan.

\section{B. Model Analisis Faktor}

Misalkan X adalah vektor acak yang diamati (diukur secara langsung) dengan $\mathrm{p}$ jumlah peubah, sebanyak $\mathrm{m}$ faktor dengan rata-rata $\mu$ dan matriks peragam $\Sigma$. Jadi dalam hal ini berlaku :

$\mathrm{X}^{\prime}=\left(\mathrm{X}_{1}, \mathrm{X}_{2}, \cdots, \mathrm{X}_{\mathrm{p}}\right), \mathrm{X} \sim \mathrm{N}_{\mathrm{p}}(\mu, \Sigma)$

$\mathrm{E}(\mathrm{X})=\mu$ dan $\operatorname{Cov}(\mathrm{X})=\Sigma$

Dalam bentuk pernyataan dikatakan bahwa vektor acak $\mathrm{X}$ berdistribusi multinormal dengan nilai rata-rata vektor $\mu$ dan matriks peragam $\Sigma$ dan hubungan antar unsur-unsur vektor $\mathrm{X}$ bisa dituliskan dalam model faktor :

$$
X-\mu=L F+\varepsilon
$$

Model Analisis Faktor menjelaskan bahwa vektor acak $X$ tergantung secara linier pada beberapa variabel acak yang tidak teramati yaitu $F_{1}, F_{2}, \cdots, F_{m}$ yang disebut faktor umum (common factors), $L$ adalah matriks konstanta (matriks loading faktor) yang tidak diketahui nilainya, $\mu$ adalah vektor konstanta, dan $\mathrm{p}$ jumlah peubah, $\varepsilon_{1}, \varepsilon_{2}, \cdots, \varepsilon_{p}$ adalah unsur vektor acak $\varepsilon$ yang disebut faktor khusus atau galat (error). Dalam hal ini diasumsikan bahwa vektor $\mathrm{F}$ dan $\varepsilon$ saling bebas. Jadi model di atas berimplikasi bahwa untuk unsur $X$ tertentu bisa dituliskan sebagai kombinasi linear dari seluruh faktor bersama dan sebuah faktor khusus $\varepsilon_{i}$, atau dapat ditulis:

$$
\begin{aligned}
& X_{1-} \mu_{1}=l_{11} F_{1}+l_{12} F_{2}+\ldots . .+l_{1 m} F_{m}+\varepsilon_{1} \\
& \quad \vdots \\
& X_{p-} \mu_{p}=l_{p 1} F_{1}+l_{p 2} F_{2}+\ldots . .+l_{p m} F_{m}+\varepsilon_{p}
\end{aligned}
$$

\section{Keterangan :}

$X_{i}=$ vektor acak yang memiliki $\mathrm{p}$ komponen pada amatan ke-i

$\mu_{i}=$ rataan dari peubah $\mathrm{ke}-\mathrm{i}$

$L_{i j}=(\mathrm{i}=1,2, \cdots, \mathrm{p} ; \mathrm{j}=1,2, \cdots, \mathrm{m})$ adalah factor loading atau bobot faktor dari peubah ke-i pada faktor bersama ke-j 
$F_{j}=$ faktor umum ke-j

$\varepsilon_{i}=$ sisaan atau error ke-i

Dalam notasi matriks, persamaan (2) dapat dinyatakan sebagai berikut :

$$
\begin{aligned}
& X-\mu=L \quad F+\varepsilon \\
& (p x 1) \quad(p x m)(m x 1) \quad(p x 1)
\end{aligned}
$$

Dimana :

$$
\begin{aligned}
\mathrm{X}^{\prime} & =\left[\begin{array}{llll}
\mathrm{X}_{1} & \mathrm{X}_{2} & \cdots & \mathrm{X}_{\mathrm{p}}
\end{array}\right] \\
\mu^{\prime} & =\left[\begin{array}{llll}
\mu_{1} & \mu_{2} & \cdots & \mu_{\mathrm{p}}
\end{array}\right] \\
L & =\left[\begin{array}{cccc}
l_{11} & l_{12} & \cdots & l_{1 m} \\
l_{21} & l_{22} & \cdots & l_{2 m} \\
\vdots & \vdots & \vdots & \vdots \\
l_{p 1} & l_{p 1} & \cdots & l_{p m}
\end{array}\right] \text { disebut matriks bobot faktor (matrix of factor loadings) } \\
F^{\prime} & =\left[\begin{array}{llll}
\mathrm{F}_{1} & \mathrm{~F}_{2} & \cdots & \mathrm{F}_{m}
\end{array}\right] \quad \varepsilon^{\prime}=\left[\begin{array}{llll}
\varepsilon_{1} & \varepsilon_{2} & \cdots & \varepsilon_{\mathrm{p}}
\end{array}\right]
\end{aligned}
$$

\section{Dengan asumsi bahwa :}

1. $E(F)=0$

2. $E(\varepsilon)=0$

3. $\operatorname{Cov}(\mathrm{F}, \varepsilon)=0$

4. $\operatorname{Cov}(F)=\operatorname{Var}(F)=E\left(F F^{\prime}\right)=I_{m x m}$

5. $\operatorname{Cov}(\varepsilon)=\operatorname{Var}(\varepsilon)=\mathrm{E}\left(\varepsilon \varepsilon^{\prime}\right)=\psi=\left[\begin{array}{cccc}\psi_{1} & 0 & \cdots & 0 \\ 0 & \psi_{2} & \cdots & 0 \\ \vdots & \vdots & \ddots & \vdots \\ 0 & 0 & \cdots & \psi_{\mathrm{p}}\end{array}\right]$ dengan $\psi_{\mathrm{i}}>0$

Jika $F$ dan $\varepsilon$ saling bebas maka $\operatorname{Cov}\left(\varepsilon F^{\prime}\right)=\mathrm{E}\left(\varepsilon F^{\prime}\right)=0$

Dengan asumsi di atas maka membawa implikasi pada stuktur kovarians untuk matriks $X$ dari persamaan (1) menjadi :

$$
\begin{aligned}
(X-\mu)(X-\mu)^{\prime} & =(L F+\varepsilon)(L F+\varepsilon)^{\prime} \\
& =(L F+\varepsilon)\left((L F)^{\prime}+\varepsilon^{\prime}\right) \\
& =L F(L F)^{\prime}+\varepsilon(L F)^{\prime}+L F \varepsilon^{\prime}+\varepsilon \varepsilon^{\prime} \\
& =L F F^{\prime} L^{\prime}+\varepsilon F^{\prime} L^{\prime}+L F \varepsilon^{\prime}+\varepsilon \varepsilon^{\prime}
\end{aligned}
$$

Sehingga:

$$
\begin{aligned}
\sum=\operatorname{Cov}(X) & =E(X-\mu)(X-\mu)^{\prime} \\
& =E\left(L F F^{\prime} L^{\prime}+\varepsilon F^{\prime} L^{\prime}+L F \varepsilon^{\prime}+\varepsilon \varepsilon^{\prime}\right) \\
& =L E\left(F F^{\prime}\right) L^{\prime}+E\left(\varepsilon F^{\prime}\right) L^{\prime}+L E\left(F \varepsilon^{\prime}\right)+E\left(\varepsilon \varepsilon^{\prime}\right) \\
& =L I L^{\prime}+0+0+\Psi \\
& =L L^{\prime}+\Psi
\end{aligned}
$$

Menurut persamaan (4). Karena saling lepas, maka $\operatorname{Cov}(\varepsilon, F)=E\left(\varepsilon, F^{\prime}\right)=0$ 
Dari persamaan (1) kita peroleh:

$$
\begin{aligned}
& (X-\mu) F^{\prime}=(L F+\varepsilon) F^{\prime}=L F F^{\prime}+\varepsilon F^{\prime} \\
& \operatorname{Cov}(X, F)=E(X-\mu) F^{\prime}=L E\left(F F^{\prime}\right)+E\left(\varepsilon F^{\prime}\right)=L
\end{aligned}
$$

Bentuk Covarians Dari Model Faktor Orthogonal

$$
\begin{aligned}
& \operatorname{Cov}(X)=L L^{\prime}+\Psi \quad \text { atau } \\
& \operatorname{Var}\left(X_{i}\right)=\sigma_{i i}=l^{2}{ }_{i 1}+l_{i 2}^{2}+\ldots .+l^{2}{ }_{i m}+\Psi
\end{aligned}
$$

atau

$$
\begin{aligned}
& \operatorname{Var}\left(X_{i}\right)=\sigma_{i i}=h_{i}^{2}+\Psi_{i} \\
& \operatorname{Var}\left(\mathrm{X}_{\mathrm{i}}\right)=\text { komunaliti }+ \text { spesifik varian }
\end{aligned}
$$

Dimana : $h_{i}^{2}=l^{2}{ }_{i 1}+l_{i 2}^{2}+\ldots .+l^{2}{ }_{i m}=\sum_{j=1}^{m} l_{i j}$

Dari persamaan (5) tampak bahwa ragam dari vektor acak $\mathrm{X}_{\mathrm{i}}$ diterangkan oleh dua komponen yaitu komponen $h_{i}^{2}$ (communality ke-i) dan komponen $\Psi_{i}$ (varian spesifik ke-i). Bagian dari $\operatorname{Var}\left(\mathrm{X}_{\mathrm{i}}\right)$ yang dapat diterangkan oleh faktor bersama disebut komunalitas (communality) ke-i atau $h_{i}^{2}$. Sedangkan bagian dari $\operatorname{Var}\left(\mathrm{X}_{\mathrm{i}}\right)$ karena faktor spesifik disebut varian spesifik ke-i atau $\Psi_{i}$.

Misalkan untuk vektor acak $\mathrm{X}_{\mathrm{i}}$ dan $\mathrm{X}_{\mathrm{k}}, \mathrm{i} \neq \mathrm{k}(\mathrm{i}, \mathrm{k}=1,2, \ldots, \mathrm{p})$ dimana $l_{i}$ dan $l_{k}$ adalah baris ke-i dan kolom ke-j dari matriks L maka peragamnya dapat ditulis sebagai berikut :

$$
\operatorname{cov}\left(x_{i}, x_{k}\right)=\sum_{j=1}^{m} l_{i j} l_{k j}=l_{i 1} l_{k 1}+l_{i 2} l_{k 2}+\ldots+l_{i m} l_{k m}
$$

sedangkan untuk vektor acak $\mathrm{X}_{\mathrm{i}}$ dan faktor ke-j $\left(\mathrm{F}_{\mathrm{j}}\right)$, ditentukan sebagai berikut :

$$
\begin{array}{r}
\operatorname{cov}\left(x_{i}, x_{j}\right)=l_{i j} \quad ; i=1,2, \cdots, p \\
j=1,2, \cdots, m
\end{array}
$$

Apabila Analisis Faktor didasarkan pada matriks peragam $\Sigma$ maka besarnya keragaman yang dapat diterangkan oleh faktor ke-j $(j=1,2, \ldots, m)$ ditentukan sebagai berikut :

Peranan $\mathrm{F}_{\mathrm{j}}=\frac{l_{1 j}^{2}+l_{2 j}^{2}+\cdots+l_{p j}^{2}}{\lambda_{1}+\lambda_{2}+\cdots+\lambda_{p}} \times 100 \%=\frac{\sum_{i=1}^{p} l_{i j}^{2}}{\operatorname{tr}(\Sigma)} \times 100 \%$

Sedangkan apabila didasarkan pada matriks korelasi $\mathrm{R}$ dimana $\mathrm{p}$ adalah banyaknya variabel $\mathrm{X}_{\mathrm{i}}$ maka dapat ditentukan sebagai berikut:

$$
\text { Peranan } \mathrm{F}_{\mathrm{j}}=\frac{\sum_{i=1}^{p} l_{i j}^{2}}{\operatorname{tr}(R)} \times 100 \%=\frac{\sum_{i=1}^{p} l_{i j}^{2}}{p} \times 100 \%
$$

\section{Statistik yang Relevan dengan Analisis Faktor}

Statistik yang relevan dengan analisis faktor adalah : Bartlett's test of sphericity, yaitu suatu uji statistik yang dipergunakan untuk menguji hipotesis bahwa variabel tidak saling berkorelasi dalam populasi, dengan kata lain matriks korelasi populasi merupakan matriks identitas; Communality ialah jumlah varian yang disumbangkan oleh suatu variabel dengan seluruh variabel lainnya dalam 
analisis, dapat juga disebut proporsi atau bagian varian yang dijelaskan oleh common factor atau besarnya sumbangan suatu faktor terhadap varians seluruh variabel; Eigenvalue merupakan jumlah varians yang dijelaskan oleh setiap faktor; Factor loadings adalah korelasi sederhana antara variabel dengan faktor; Factor loading plot ialah suatu plot dari variabel asli dengan menggunakan fakcor loadings sebagai koordinat; Factor matrix yaitu yang memuat semua factor loading dari semua variabel pada semua factor extracted; Factor scores merupakan skor komposit yang diduga untuk setiap responden pada faktor turunan (derived factors); Kaiser-Meyer-Olkin (KMO), Measure of Sampling Adequacy (MSA) merupakan suatu indeks yang dipergunakan untuk meneliti ketepatan analisis faktor. Nilai tinggi antara 0,5 - 1,0 berarti analisis faktor tepat, kalau kurang dari 0,5 analisis faktor dikatakan tidak tepat; Percentage of variance merupakan persentase varians total yang disumbangkan oleh setiap faktor; Residuals adalah perbedaan antara korelasi yang terobservasi berdasarkan input correlation matrix dan korelasi hasil reproduksi yang diperkirakan dari matriks faktor; Scree plot merupakan plot dari nilai eigen sebagai sumbu tegak (vertical) dan banyaknya faktor sebagai sumbu datar, untuk menentukan banyaknya faktor yang bisa ditarik (factor extraction).

\section{Metode Pendugaan Analisis Faktor}

Metode pendugaan dalam analisis faktor terdiri dari metode non-iteratif dan metode iteratif. Metode yang termasuk dalam kelompok non-iteratif antara lain : metode komponen utama (principal component method), metode faktor utama (principal factor method), analisis citra (image analysis) dan analisis faktor kanonik non-iteratif Harris (Harris' non-iterative canonical factor analysis). Sedangkan yang termasuk dalam kelompok metode iteratif adalah metode kemungkinan maksimum (maximum likelihood method), metode kuadrat kecil tak terboboti (unweighted least squares, ULS), metode komponen utama iteratif (iterative principal component method), dan analisis faktor alpha (alpha factor analysis).

Metode pendugaan yang akan dibahas dalam buku ini adalah bagian dari metode non-iteratif yaitu metode komponen utama (KU). Metode komponen utama pada analisis faktor adalah metode yang paling sederhana.

Beberapa prosedur bisa digunakan dalam penentuan banyaknya faktor yang akan digunakan, antara lain penentuan secara apriori (berdasarkan pengalaman sebelumnya peneliti sudah tahu berapa banyaknya faktor yang sebenarnya), penentuan berdasarkan eigen values (hanya faktor dengan nilai eigen lebih besar dari satu yang digunakan dalam moodel), dan berdasarkan scree plot.

Misal $\boldsymbol{\Sigma}$ merupakan matriks peragam dari matriks pengamatan $\mathbf{X}$ yang memiliki pasangan nilai akar ciri (eigen value) dan vektor cirinya $\left(\lambda_{\mathrm{i}}, \underline{\mathbf{e}}_{\mathrm{i}}\right)$ dengan $\lambda_{1} \geq \lambda_{2} \geq \ldots \geq \lambda_{\mathrm{p}}$. Dengan spectral dekomposisi didapatkan

$$
\Sigma=\lambda_{1} \underline{\mathbf{e}}_{1} \underline{\mathbf{e}}_{1} \underline{\prime}+\lambda_{2} \underline{\mathbf{e}}_{2} \underline{\mathbf{e}}_{2} \underline{\prime}+\ldots . .+\lambda_{\mathrm{p}} \underline{\mathbf{e}}_{\mathrm{p}} \underline{\mathbf{e}}_{\mathrm{p}} \text {, }
$$




$$
=\left[\sqrt{ } \lambda_{1} \underline{\mathbf{e}}_{1}\left|\sqrt{ } \lambda_{2} \underline{\mathbf{e}}_{2}\right| \sqrt{ } \lambda_{3} \underline{\mathbf{e}}_{3}|\ldots| \sqrt{ } \lambda_{\mathrm{p}} \underline{\mathbf{e}}_{\mathrm{p}}\right]\left[\begin{array}{c}
\sqrt{\lambda_{1}} \underline{\mathbf{e}}_{1} \\
\sqrt{\lambda_{2}} \underline{\mathbf{e}}_{2} \\
\vdots \\
\sqrt{\lambda_{p}} \underline{\mathbf{e}}_{p}
\end{array}\right]
$$

Dari penjelasan di atas, bila $\mathrm{m}=\mathrm{p}$, maka

$$
\begin{aligned}
& \boldsymbol{\Sigma}=\mathbf{L} \quad \mathbf{L}^{\prime}+\mathbf{O}=\mathbf{L} \mathbf{L}^{\prime} \\
& \text { (pxp) (pxp) (pxp) (pxp) }
\end{aligned}
$$

Hal tersebut di atas kurang bagus untuk menyamakan model KU dengan model faktor. Akan tetapi dapat dikatakan bahwa nilai akar ciri sebanyak p-m cukup kecil dan dapat diabaikan sehingga matriks kovarian di atas dapat diubah

$$
\boldsymbol{\Sigma} \cong\left[\sqrt{ } \lambda_{1} \underline{\mathbf{e}}_{1}\left|\sqrt{ } \lambda_{2} \underline{\mathbf{e}}_{2}\right| \sqrt{ } \lambda_{3} \underline{\mathbf{e}}_{3}|\ldots| \sqrt{ } \lambda_{\mathrm{m}} \underline{\mathbf{e}}_{\mathrm{m}}\right]\left[\begin{array}{c}
\sqrt{\lambda_{1}} \underline{\mathbf{e}}_{1} \\
\sqrt{\lambda_{2}} \underline{\mathbf{e}}_{2} \\
\vdots \\
\sqrt{\lambda_{p}} \underline{\mathbf{e}}_{m}
\end{array}\right]
$$

$$
=\mathbf{L} \quad \mathbf{L}
$$

pxm mxp

Nilai pendekatan diatas akan menghasilkan suatu galat, oleh itu nilai spesifik factor dapat ditambahkan sebagai pendekatan. Sehingga model tersebut menjadi

$$
\boldsymbol{\Sigma} \cong\left[\sqrt{ } \lambda_{1} \underline{\mathbf{e}}_{1}\left|\sqrt{ } \lambda_{2} \underline{\mathbf{e}}_{2}\right| \sqrt{ } \lambda_{3} \underline{\mathbf{e}}_{3}|\ldots| \sqrt{ } \lambda_{\mathrm{m}} \underline{\mathbf{e}}_{\mathrm{m}}\right]\left[\begin{array}{c}
\sqrt{\lambda_{1}} \underline{\mathbf{e}}_{1} \\
\sqrt{\lambda_{2}} \underline{\mathbf{e}}_{2} \\
: \\
\sqrt{\lambda_{p}} \underline{\mathbf{e}}_{m}
\end{array}\right]+\left[\begin{array}{cccc}
\psi_{1} & 0 & 0 & 0 \\
0 & \psi_{2} & 0 & 0 \\
: & : & : & : \\
0 & 0 & 0 & \psi_{p}
\end{array}\right]
$$

Dimana

$\Psi \mathrm{i}=\sigma_{i i}-\sum_{j=1}^{m} l_{i j}^{2}$ untuk $\mathrm{i}=1,2, \ldots, \mathrm{p}$

Misal $\boldsymbol{\Sigma}$ merupakan matriks peragam dari matriks pengamatan $\mathbf{X}$ yang memiliki pasangan nilai akar ciri (eigenvalue) dan vektor cirinya $\left(\lambda_{\mathrm{i}}, \underline{\mathbf{e}}_{\mathrm{i}}\right)$ dengan $\lambda_{1} \geq \lambda_{2} \geq \ldots \geq \lambda_{\mathrm{p}}$. Misalkan $\mathrm{m}<\mathrm{p}$ merupakan jumlah peubah dari faktor umum (common factor).

- Matriks penduga faktor loadingnya $\left\{1_{\mathrm{ij}}\right\}$ yaitu: $\mathbf{L}=\left[\sqrt{ } \lambda_{1} \underline{\mathbf{e}}_{1}\left|\sqrt{ } \lambda_{2} \underline{\mathbf{e}}_{2}\right| \sqrt{ } \lambda_{3} \underline{\mathbf{e}}_{3}|\ldots| \sqrt{\lambda_{\mathrm{m}}} \underline{\mathbf{e}}_{\mathrm{m}}\right]$

- Penduga ragam spesifik adalah $\Psi=\mathbf{S}-\mathbf{L}^{\prime} \mathbf{L}^{\prime}$ dan $R \approx \hat{L} \hat{L}^{\prime}+\hat{\Psi}$

- Nilai komunalitas untuk peubah ke-i: $\mathrm{h}_{\mathrm{i}}{ }^{2}=\mathrm{l}_{\mathrm{i} 1}{ }^{2}+\mathrm{l}_{\mathrm{i} 2}{ }^{2}+\ldots+\mathrm{l}_{\mathrm{im}}{ }^{2}$

Kontribusi total dari ragam peubah contoh yaitu:

$$
\mathrm{s}_{11}+\mathrm{s}_{22}+\ldots+\mathrm{s}_{\mathrm{pp}}=\operatorname{tr}(\mathrm{S})
$$

Secara umum proporsi dari total ragam peubah untuk faktor yang ke-j adalah: 
$\mathrm{s}_{11}+\mathrm{s}_{22}+\ldots+\mathrm{s}_{\mathrm{pp}}$

Untuk analisis faktor R (matriks korelasi)

$\mathrm{p}$

\section{E. Rotasi Faktor}

Faktor-faktor yang diperoleh melalui metode komponen utama kadang masih sulit untuk diinterpretasikan. Seringkali variabel memiliki nilai yang hampir sama dan nampaknya tidak mempunyai korelasi dengan faktor manapun. Faktor penimbang awal yang diperoleh seringkali sulit untuk diinterpretasikan sehingga biasanya dilakukan suatu rotasi sampai struktur yang lebih sederhana diperoleh.

Hal ini dilakukan dengan cara merotasi matriks loading yaitu antara lain dengan: rotasi orthogonal varimax, rotasi quartimax, atau rotasi equimax. Penjelasan rotasi-rotasi tersebut adalah sebagai berikut:

1. Rotasi orthogonal varimax adalah rotasi yang menyederhanakan kolom dalam matriks faktor. Dengan rotasi varimax nilai variabel terbentang antara +1 sampai -1, beberapa nilai loading mendekati 0 didalam tiap kolom. Sehingga dalam interpretasi varimax dapat dilakukan dengan mudah dengan melihat korelasi dalam setiap faktor dengan memperhatikan nilainya:

A. Jika nilainya dekat dengan +1 atau -1 , mengindikasikan variabel tersebut memiliki korelasi positif atau negatif kuat dengan faktor yang terbentuk.

B. Jika nilainya dekat dengan 0 mengindikasikan bahwa korelasi variabel asal terhadap faktor yang terbentuk kecil.

2. Rotasi quartimax adalah menyederhanakan baris dalam matriks faktor. Rotasi quartimax lebih memfokuskan pada faktor terdepan sehingga diusahakan variabel memiliki nilai tertinggi di salah satu faktor dan memiliki nilai serendah-rendahnya di semua faktor yang lain. Dengan rotasi ini, banyak variabel memiliki nilai yang tinggi maupun hampir sama karena teknik ini memfokuskan pada penyederhanaan baris. Dengan quartimax tidak dapat menjelaskan dengan sukses penyederhanaan struktur, sehingga sulit dalam interpretasi faktor pertama terhadap faktor lainnya. Rotasi quartimax bukan merupakan tujuan dari rotasi yang baik.

3. Rotasi equimax yang merupakan rotasi antara varimax dan quartimax. Nilai variabel dalam masing-masing faktor terbentuk tidak maksimum dan cenderung saling berdekatan, sehingga rotasi ini jarang dipakai. Dalam penelitian sering digunakan rotasi orthogonal varimax dengan memakai rotasi tegak lurus varimax terhadap matriks loading $\hat{L}$.

$$
\hat{L}_{p x m}^{*}=\hat{L}_{p x m} T_{m x m}
$$

Dimana $\hat{L}^{*}$ adalah matriks bobot faktor (matriks loading) setelah dirotasikan dan $\mathrm{T}$ adalah matriks transformasi yang dipilih sehingga $\mathrm{TT}^{\prime}=\mathrm{T}^{\prime \prime} \mathrm{T}=1$. Dari perumusan ini terlihat jelas bahwa rotasi merupakan suatu upaya untuk menghasilkan fakor penimbang baru agar lebih mudah untuk diinterpretasikan, yaitu dengan cara mengalikan faktor penimbang awal dengan suatu matriks transformasi yang bersifat orthogonal. Walaupun telah dirotasi, matriks kovarian 
(korelasi) tidak berubah karena $\hat{L} \hat{L}^{\prime}+\hat{\Psi}=\hat{L} \mathrm{TT}^{\prime} \hat{L}^{\prime}+\hat{\Psi}=\hat{L}^{*} \hat{L}^{*}+\hat{\Psi}$ selanjutnya varian spesifik $\Psi_{i}$ dan communality $h_{i}^{2}$ juga tidak berubah.

Rotasi varimax merupakan rotasi yang membuat jumlah varian faktor loading atau bobot faktor dalam masing-masing faktor akan menjadi maksimum, dimana nantinya peubah asal hanya akan mempunyai korelasi yang tinggi dan kuat dengan faktor tertentu saja (korelasi mendekati 1) dan tentunya memiliki korelasi lemah dengan faktor lainnya (korelasi mendekati 0).

\section{F. ILUSTRASI}

Pada Tabel 8.1 terdapat 37 variabel yang diamati dan merupakan motivasi seseorng menjadi tenaga kerja illegal (Geradus dkk, 2018).

\section{Tabel 8.1 Variabel Penelitian}

\begin{tabular}{|c|c|}
\hline variabel & Pernyataan \\
\hline$\overline{\mathrm{X} 1}$ & $\begin{array}{l}\text { Saya menjadi TKW karena saya tidak mengetahui kalau itu ada bentuk } \\
\text { penipuan }\end{array}$ \\
\hline $\mathrm{X} 2$ & $\begin{array}{l}\text { Saya menjadi TKW karena saya tidak tahu TKW biasanya menjadi } \\
\text { budak }\end{array}$ \\
\hline $\mathrm{X} 3$ & Saya menjadi TKW karena saya diajak teman \\
\hline $\mathrm{X} 4$ & $\begin{array}{l}\text { Saya menjadi TKW karena saya tidak mempunyai biaya yang cukup } \\
\text { untuk kehidupan sehari-hari }\end{array}$ \\
\hline $\mathrm{X} 5$ & Saya menjadi TKW karena saya ingin mempunyai banyak uang \\
\hline X6 & Sayamenjadi TKW karena saya merasa miskin \\
\hline $\mathrm{X} 7$ & Saya menjadi TKW karena saya ingin cepat kaya \\
\hline $\mathrm{X} 8$ & Saya menjadi TKW karena saya ingin memiliki barang-barang berharga \\
\hline $\mathrm{X} 9$ & Saya menjadi TKW karena saya ingin mempunyai rumah yang mewah \\
\hline $\mathrm{X} 10$ & Saya menjadi TKW karena saya mempunyai kehidupan yang tidak layak \\
\hline $\mathrm{X} 11$ & Saya menjadi TKW karena saya mempunyai banyak utang \\
\hline $\mathrm{X} 12$ & Saya menjadi TKW karena budaya kami mendiskriminasi perempuan \\
\hline $\mathrm{X} 13$ & Saya menjadi TKW karena saya perempuan \\
\hline X14 & $\begin{array}{l}\text { Saya menjadi TKW karena saya sebagai perempuan dianggap lebih } \\
\text { mudah mencari pekerjaan di luar daerah }\end{array}$ \\
\hline $\mathrm{X} 15$ & Saya menjadi TKW karena saya hanya lulusan SD/SMP \\
\hline $\mathrm{X} 16$ & Saya menjadi TKW karena pendidikan saya rendah \\
\hline $\mathrm{X} 17$ & Saya menjadi TKW karena saya putus sekolah \\
\hline $\mathrm{X} 18$ & Saya menjadi TKW karena saya sulit mendapat pekerjaan yang lain \\
\hline X19 & Saya menjadi TKW karenasaya sulit mendapat pekerjaan yang layak \\
\hline $\mathrm{X} 20$ & $\begin{array}{l}\text { Saya menjadi TKW karena saya hanya bisa menjadi pembantu rumah } \\
\text { tangga }\end{array}$ \\
\hline $\mathrm{X} 21$ & $\begin{array}{l}\text { Saya menjadi TKW karena saya tidak pernah mendapatkan informasi } \\
\text { tentang bahaya/risiko menjadi TKW }\end{array}$ \\
\hline $\mathrm{X} 22$ & $\begin{array}{l}\text { Saya menjadi TKW karena saya mendapati nformasi bahwa TKW } \\
\text { mendapat gaji yang besar }\end{array}$ \\
\hline $\mathrm{X} 23$ & $\begin{array}{l}\text { Saya menjadi TKW karena saya menjadi tulang punggung keluarga } \\
\text { dalam mencari nafkah }\end{array}$ \\
\hline $\mathrm{X} 24$ & $\begin{array}{l}\text { Saya menjadi TKW karena saya dianggap paling mampu mencar iuang } \\
\text { di luar daerah }\end{array}$ \\
\hline $\mathrm{X} 25$ & $\begin{array}{l}\text { Saya menjadi TKW karena saya membiayai saudara saya yang sedang } \\
\text { sekolah }\end{array}$ \\
\hline
\end{tabular}


X26 Saya menjadi TKW karena orang tua ingin saya membangun rumah

X27 Saya menjadi TKW karena saya ingin mempunyai suami orang luar negeri

X28 Saya menjadi TKW karena saya menikah di usia dini dan suami tidak bertanggung jawab

X29 Saya menjadi TKW karena saya gagal dalam berumah tangga

X30 Saya menjadi TKW karena saya mempunyai anak yang membutuhkan biaya

X31 Saya menjadi TKW karena saya ingin keluar dari kampung/daerah saya

X32 Saya menjadi TKW karena saya merasa tidak berkembang tinggal di kampung

X33 Saya menjadi TKW karena saya ditawarkan pekerjaan

X34 Saya menjadi TKW karena saya beranggapan bahwa hukum di Indonesia bisa diatur

X35 Saya menjadi TKW karena saya merasa aturan hukum Indonesia melindungi saya

X36 Saya menjadi TKW karena penegak hukum di Indonesia bisa membantu saya untuk mendapatkan pekerjaan

X37 Saya menjadi TKW karena saya merasa penegak hukum melindungi saya apabila saya mendapat masalah

Setiap variabel yang diamati diberi nilai 1-5, yaitu :

$1=$ Sangat tidak setuju

2 = Tidak setuju

$3=$ Cukup setuju

$4=$ Setuju

5 = Sangat setuju

1. Apa faktor-faktor penyebab terjadinya human trafficking di NTT?

2. Apakah faktor utama penyebab terjadinya human trafficking?

\section{Jawab :}

\section{Uji KMO, Bartlett, dan MSA}

Sebagaimana diketahui bahwa data merupakan komponen sangat penting dalam analisis kuantitatif. KMO ini merupakan suatu uji untuk menunjukkan apakah metode sampling yang digunakan memenuhi syarat atau tidak, yang berimplikasi apakah data dapat dianalisis lebih lanjut atau tidak. Sedangkan uji Bartlett adalah pengujian yang digunakan untuk melihat apakah variabel yang digunakan berkorelasi dengan variabel lainnya. Jika tidak berkorelasi maka tidak dapat dianalisi lebih lanjut.

\section{Tabel 8.2 Uji KMO and Bartlett}

\begin{tabular}{llr}
\hline $\begin{array}{l}\text { Kaiser-Meyer-Olkin Measure of Sampling } \\
\text { Adequacy }\end{array}$ & 0.729 \\
\hline Bartlett's Test of & Approx. Chi-Square & $1.173 \mathrm{E} 3$ \\
Sphericity & df & 465 \\
& Sig. & 0.000 \\
\hline
\end{tabular}


Berdasarkan Tabel 8.2, diketahui bahwa nilai KMO adalah 0.729 dengan nilai signifikansi Bartlett sbesar 0.000. Hal ini menunjukkah bahwa variabel dan sampel yang ada sudah bisa dianalisis lebih lanjut dengan menggunakan analisis faktor.

Untuk Tabel 8.3 (Lampiran 1) dapat kita peroleh informasi mengenai nilai MSA 37 variabel. Pada Tabel 8.3 tersebut nilai MSA terletak pada diagonal Anti Image Correlation, dan terlihat bahwa nilai MSA beberapa variabel berada di bawah 0.5 sehingga variabel-variabel tersebut satu persatu dikeluarkan dengan cara mrngeluarkan terlebih dahulu variabel dengan nilai MSA terkecil dan dilakukan pengujian ulang sampai diperoleh nilai MSA semua variabel bernilai minimal 0.5. Setelah melalui delapan kali pengujian ulang maka diperoleh nilai MSA setiap variabel di atas 0.5 dengan tersisa 31 variabel yaitu $X_{1}, X_{2}, X_{3}, X_{4}$, $\mathrm{X}_{5}, \mathrm{X}_{6}, \mathrm{X}_{7}, \mathrm{X}_{8}, \mathrm{X}_{9}, \mathrm{X}_{10}, \mathrm{X}_{11}, \mathrm{X}_{12}, \mathrm{X}_{13}, \mathrm{X}_{14}, \mathrm{X}_{15}, \mathrm{X}_{16}, \mathrm{X}_{17}, \mathrm{X}_{18}, \mathrm{X}_{19}, \mathrm{X}_{20}, \mathrm{X}_{21}, \mathrm{X}_{22}$, $X_{23}, X_{24}, X_{25}, X_{26}, X_{27}, X_{28}, X_{29}, X_{30}, X_{32}$. Sedangkan enam variabel yaitu $X_{31}$, $X_{33}, X_{34}, X_{35}, X_{36}, X_{37}$ tidak dimasukkan ke dalam analisis faktor, di mana keenam variabel yang dimaksud semuanya berhubungan dengan masalah hukum kecuali $\mathrm{X}_{31}$. Hal ini berarti bahwa untuk 31 variabel tersebut bisa dilakukan proses analisis faktor.

\section{Analisis Faktor}

Nilai komunalitas merupakan proporsi varian variabel awal yang dapat dijelaskan oleh faktor yang ada. Semakin besar nilai komunalitas maka semakin besar pula hubungan variabel dengan faktor. Hal ini dijelaskan oleh nilai komunalitas Extraction seperti pada Tabel 8.4. Berdasarkan tabel tersebut, terlihat bahwa semua nilai komunalitas Extraction di atas 0.5, artinya hubungan antara variabel dan faktor relative besar. Dengan hasil yang diperoleh tersebut maka variabel-variabel yang digunakan telah mendapatkan faktor yang baik, karena faktor merepresentasikan keragaman/varians dari variabel-variabel yang digunakan yang ditunjukkan oleh tingginya hubungan antara variabel dan faktor. Nilai komunalitas adalah jumlah kuadrat masing-masing faktor loading (bobot faktor). Misalnya untuk $\mathrm{X}_{1}$ : Kumunalitas $=(0.200)^{2}+(-0.081)^{2}+(0.064)^{2}+$ $(0.104)^{2}+(0.162)^{2}+(0.850)^{2}+(0.178)^{2}=0.842$

Untuk variabel $\mathrm{X}_{1}$, nilai komunalitasnya adalah 0.842 , hal ini berarti sekitar $84.2 \%$ varians $\mathrm{X}_{1}$ bisa dijelaskan oleh faktor yang terbentuk. Untuk variabel $\mathrm{X}_{2}$ nilai komunalitasnya sebesar 0.837 yang berarti bahwa $83.7 \%$ varians $\mathrm{X}_{2}$ bisa dijelaskan oleh faktor yang terbentuk. Dan seterusnya sampai variabel ke31 yaitu $\mathrm{X}_{32}$ dengan nilai kumunalitas 0.635 atau sekitar $63.5 \%$ varians $\mathrm{X}_{32}$ bisa dijelaskan oleh faktor uang terbentuk. Begitupula untuk variabel-variabel yang lain, dengan ketentuan bahwa semakin besar nilai komunalitas sebuah variabel, berarti semakin erat hubungannya dengan faktor yang terbentuk.

Nilai-nilai yang ada (Tabel 8.4) menunjukkan kemampuan faktor-faktor yang terbentuk dalam menjelaskan varians peubah asal. Nilai yang terbesar dimiliki variabel $\mathrm{X}_{7}$ yaitu sebesar 0,897 artinya sebesar $89.7 \%$ varians dari variabel $\mathrm{X}_{7}$ dapat dijelaskan oleh faktor yang terbentuk. Sedangkan nilai yang terkecil dimiliki variabel $\mathrm{X}_{27}$ sebesar 0,620. Semakin besar nilai komunaliti sebuah variabel, maka semakin erat hubungannya dengan faktor yang terbentuk. 
Tabel 8.4 Nilai komunalitas

\begin{tabular}{cccccc} 
Variabel & Initial & Extraction & Variabel & Initial & Extraction \\
\hline X1 & 1.000 & 0.842 & X17 & 1.000 & 0.763 \\
X2 & 1.000 & 0.837 & X18 & 1.000 & 0.698 \\
X3 & 1.000 & 0.669 & X19 & 1.000 & 0.764 \\
X4 & 1.000 & 0.673 & X20 & 1.000 & 0.692 \\
X5 & 1.000 & 0.691 & X21 & 1.000 & 0.688 \\
X6 & 1.000 & 0.810 & X22 & 1.000 & 0.833 \\
X7 & 1.000 & 0.897 & X23 & 1.000 & 0.820 \\
X8 & 1.000 & 0.763 & X24 & 1.000 & 0.845 \\
X9 & 1.000 & 0.695 & X25 & 1.000 & 0.735 \\
X10 & 1.000 & 0.767 & X26 & 1.000 & 0.804 \\
X11 & 1.000 & 0.656 & X27 & 1.000 & 0.620 \\
X12 & 1.000 & 0.778 & X28 & 1.000 & 0.839 \\
X13 & 1.000 & 0.727 & X29 & 1.000 & 0.842 \\
X14 & 1.000 & 0.692 & X30 & 1.000 & 0.676 \\
X15 & 1.000 & 0.768 & X32 & 1.000 & 0.635 \\
X16 & 1.000 & 0.893 & & & \\
\hline
\end{tabular}

Pemfaktoran merupakan proses inti dalam analisis faktor, yaitu melakukan sejumlah ekstraksi pada variabel-variabel yang ada, sehingga terbentuk satu atau lebih faktor yang berisi sejumlah variabel. Banyak metode yang dapat digunakan untuk melakukan proses ekstraksi untuk menduga bobot faktor. Namun pada penelitian ini, peneliti menggunakan Metode Komponen Utama (Principal Component Analysis). Dalam metode komponen utama, kriteria penentuan jumlah faktor yang akan terbentuk dapat dilihat dari variabel yang memiliki nilai eigen $\lambda_{\mathrm{i}} \geq 1$. Penentuan total keragaman (varians) sangat dibutuhkan untuk dapat melihat seberapa besar informasi yang dijelaskan oleh faktor yang akan dibentuk terhadap variabel-variabel di dalam faktor tersebut.. Ada 31 variabel yang dimasukkan ke dalam analisis faktor. Berdasarkan Tabel 8.5, diketahui bahwa faktor ke-1 mempunyai nilai eigen 11.602 dengan varians $37.425 \%$. Faktor ke-2 nilai eigen 2.939 dengan varians $9.482 \%$, faktor ke-3 nilai eigen 2.570 dengan varians $8.289 \%$ dan seterusnya sampai faktor ke-31 dengan nilai eigen 0.02 dan varians $0.063 \%$.

Tabel 8.5 Hasil ekstraksi faktor dengan metode komponen utama

\begin{tabular}{|c|c|c|c|c|c|c|c|c|c|}
\hline \multirow{2}{*}{$\begin{array}{l}\text { Comp } \\
\text { onent }\end{array}$} & \multicolumn{3}{|c|}{ Initial Eigenvalues } & \multicolumn{3}{|c|}{$\begin{array}{l}\text { Extraction Sums of Squared } \\
\text { Loadings }\end{array}$} & \multicolumn{3}{|c|}{$\begin{array}{c}\text { Rotation Sums of Squared } \\
\text { Loadings }\end{array}$} \\
\hline & Total & $\begin{array}{c}\% \text { of } \\
\text { Variance }\end{array}$ & $\begin{array}{c}\text { Cumulative } \\
\%\end{array}$ & Total & $\begin{array}{c}\% \text { of } \\
\text { Variance }\end{array}$ & $\begin{array}{c}\text { Cumulative } \\
\%\end{array}$ & Total & $\begin{array}{c}\% \text { of } \\
\text { Variance }\end{array}$ & $\begin{array}{c}\text { Cumulative } \\
\%\end{array}$ \\
\hline 1 & 11.602 & 37.425 & 37.425 & 11.602 & 37.425 & 37.425 & 4.115 & 13.275 & 13.275 \\
\hline 2 & 2.939 & 9.482 & 46.907 & 2.939 & 9.482 & 46.907 & 3.998 & 12.896 & 26.171 \\
\hline 3 & 2.570 & 8.289 & 55.196 & 2.570 & 8.289 & 55.196 & 3.965 & 12.790 & 38.961 \\
\hline 4 & 2.171 & 7.004 & 62.200 & 2.171 & 7.004 & 62.200 & 3.154 & 10.174 & 49.135 \\
\hline 5 & 1.501 & 4.840 & 67.040 & 1.501 & 4.840 & 67.040 & 3.090 & 9.969 & 59.105 \\
\hline 6 & 1.411 & 4.551 & 71.592 & 1.411 & 4.551 & 71.592 & 3.027 & 9.764 & 68.869 \\
\hline 7 & 1.217 & 3.927 & 75.519 & 1.217 & 3.927 & 75.519 & 2.061 & 6.650 & 75.519 \\
\hline 8 & 0.947 & 3.055 & 78.574 & & & & & & \\
\hline 9 & 0.827 & 2.669 & 81.243 & & & & & & \\
\hline 10 & 0.786 & 2.536 & 83.779 & & & & & & \\
\hline
\end{tabular}




\begin{tabular}{llll}
11 & 0.745 & 2.403 & 86.182 \\
12 & 0.607 & 1.957 & 88.139 \\
13 & 0.571 & 1.842 & 89.982 \\
14 & 0.453 & 1.460 & 91.441 \\
15 & 0.383 & 1.237 & 92.678 \\
16 & 0.356 & 1.147 & 93.825 \\
17 & 0.311 & 1.003 & 94.829 \\
18 & 0.268 & 0.865 & 95.693 \\
19 & 0.262 & 0.847 & 96.540 \\
20 & 0.201 & 0.648 & 97.188 \\
21 & 0.145 & 0.467 & 97.655 \\
22 & 0.139 & 0.447 & 98.102 \\
23 & 0.119 & 0.383 & 98.485 \\
24 & 0.110 & 0.355 & 98.840 \\
25 & 0.093 & 0.302 & 99.142 \\
26 & 0.073 & 0.235 & 99.377 \\
27 & 0.056 & 0.181 & 99.557 \\
28 & 0.046 & 0.148 & 99.705 \\
29 & 0.042 & 0.134 & 99.839 \\
30 & 0.030 & 0.098 & 99.937 \\
31 & 0.020 & 0.063 & 100.000 \\
\hline
\end{tabular}

Berdasarkan Tabel 8.5, jika 31 variabel diekstraksi menjadi satu faktor maka varians yang bisa dijelaskan oleh satu faktor adalah $37.425 \%$. Jika 31 variabel diekstraksi menjadi dua faktor maka varians 31 variabel yang bisa dijelaskan oleh kedua faktor adalah $46.907 \%$. Jika diekstraksi menjadi tiga faktor maka ketiga faktor bisa menjelaskan $55.196 \%$ dari variabilitas 31 variabel awal. Jika diekstraksi menjadi empat faktor maka varians 31 variabel awal yang bisa dijelaskan oleh empat faktor sebesar $62.2 \%$, jika 31 variabel diekstraksi menjadi lima faktor maka varians 31 variabel aswal yang bisa dijelaskan oleh lima faktor adalah $67.04 \%$, dan jika 31 variabel diekstraksi menjadi enam faktor maka varians 31 variabel yang bisa dijelaskan oleh keenam faktor adalah sebesar $71.519 \%$. Dengan melihat komponen-komponen (variabel-variabel) pada Tabel 8.5, hanya tujuh faktor yang digunakan untuk menjelaskan 31 variabel awal karena ada tujuh faktor yang mempunyai nilai eigen lebih besar dari satu dengan nilai komulatif varians sebesar $75.519 \%$. Gambar 8.1 memperlihatkan tampilan plot scree diagram 31 nilai eigen yang dihasilkan oleh metode komponen (faktor) utama. Ini berarti jika 31 variabel diekstraksi menjadi tujuh faktor, maka ketujuh faktor dapat menjelaskan total variabilitas 31 variabel awal sebesar $75.519 \%$ dengan tidak mengurangi informasi awal dari semua variabel tersebut, sedangkan sisanya sebesar $24.481 \%$ dijelaskan oleh faktor lain yang tidak diteliti. Untuk mempermudah interpretasi terhadap faktor, akan dilakukan rotasi faktor. 


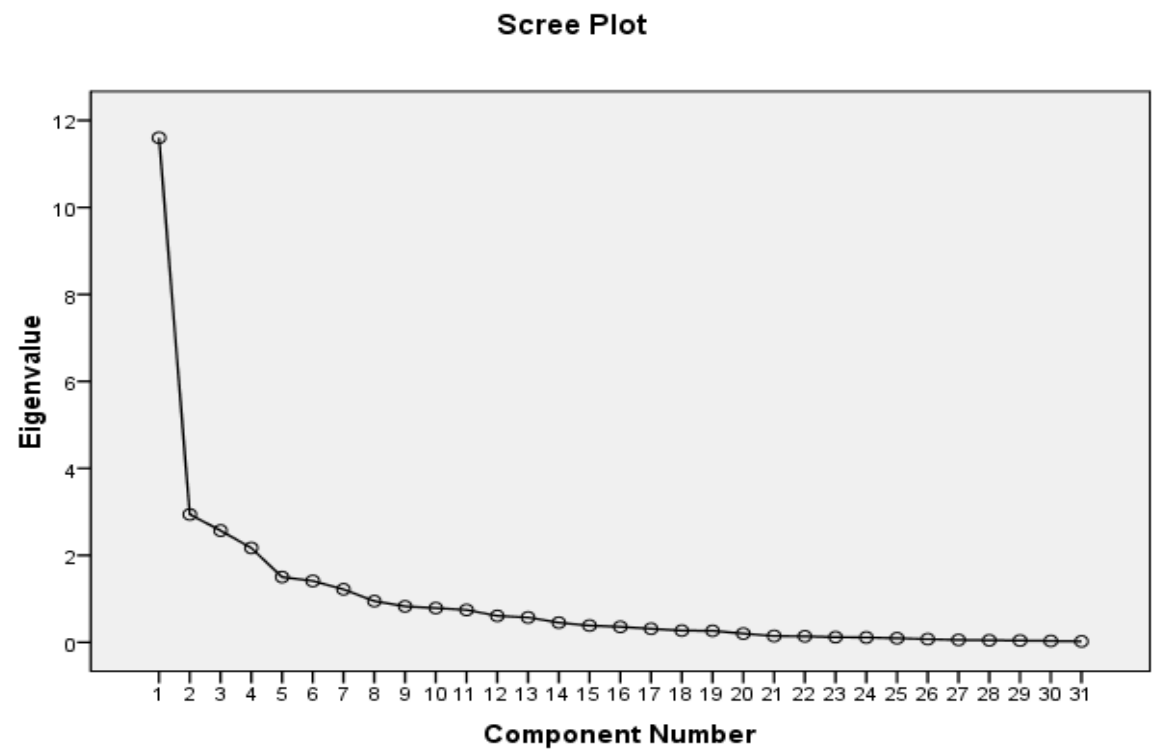

Gambar 8.1 Scree Plot

Tabel 8.6 Faktor loading (bobot faktor) setelah dirotasi varimax

\begin{tabular}{|c|c|c|c|c|c|c|c|}
\hline \multirow{2}{*}{ Variabel } & \multicolumn{7}{|c|}{ Komponent } \\
\hline & 1 & 2 & 3 & 4 & 5 & 6 & 7 \\
\hline $\mathrm{X} 1$ & 0.200 & -0.081 & 0.064 & 0.104 & 0.162 & 0.850 & 0.178 \\
\hline $\mathrm{X} 2$ & 0.168 & 0.161 & 0.099 & -0.079 & 0.258 & 0.826 & 0.136 \\
\hline X3 & 0.674 & 0.077 & 0.116 & 0.126 & 0.211 & 0.358 & 0.083 \\
\hline$X 4$ & 0.505 & 0.099 & -0.238 & 0.458 & 0.218 & 0.294 & 0.090 \\
\hline$\times 5$ & 0.573 & 0.259 & -0.103 & -0.004 & 0.223 & 0.328 & 0.357 \\
\hline$x 6$ & 0.372 & -0.096 & -0.064 & 0.275 & 0.658 & 0.240 & 0.302 \\
\hline$\times 7$ & 0.281 & 0.139 & 0.131 & 0.199 & 0.833 & 0.103 & 0.194 \\
\hline$x 8$ & 0.214 & -0.024 & 0.198 & 0.020 & 0.200 & 0.090 & 0.793 \\
\hline X9 & 0.612 & 0.194 & 0.196 & -0.117 & 0.392 & -0.019 & 0.277 \\
\hline $\mathrm{X} 10$ & 0.233 & 0.238 & 0.224 & 0.127 & 0.750 & 0.164 & 0.002 \\
\hline $\mathrm{X} 11$ & 0.410 & 0.049 & 0.202 & 0.524 & 0.358 & 0.127 & 0.159 \\
\hline$X 12$ & 0.284 & 0.067 & 0.607 & 0.081 & 0.170 & 0.219 & 0.491 \\
\hline $\mathrm{X} 13$ & 0.696 & -0.064 & 0.403 & 0.222 & 0.101 & -0.094 & 0.086 \\
\hline $\mathrm{X} 14$ & 0.714 & 0.208 & 0.122 & 0.192 & 0.135 & 0.261 & -0.008 \\
\hline$X 15$ & 0.251 & 0.207 & 0.137 & 0.743 & 0.272 & 0.133 & 0.001 \\
\hline $\mathrm{X} 16$ & 0.176 & 0.321 & 0.038 & 0.866 & 0.029 & 0.048 & -0.064 \\
\hline $\mathrm{X} 17$ & -0.084 & 0.515 & 0.301 & 0.567 & 0.222 & 0.099 & 0.144 \\
\hline$X 18$ & 0.094 & 0.783 & 0.133 & 0.155 & 0.065 & 0.154 & 0.072 \\
\hline X19 & -0.025 & 0.618 & 0.163 & 0.209 & 0.372 & 0.415 & 0.026 \\
\hline X20 & 0.007 & 0.555 & 0.306 & 0.241 & 0.060 & -0.029 & 0.477 \\
\hline X21 & 0.017 & 0.216 & 0.244 & 0.232 & -0.064 & 0.706 & -0.157 \\
\hline X22 & 0.215 & 0.633 & 0.030 & 0.232 & -0.253 & 0.467 & -0.224 \\
\hline X23 & 0.339 & 0.603 & 0.348 & 0.073 & 0.447 & 0.029 & -0.116 \\
\hline X24 & 0.517 & 0.625 & 0.196 & 0.128 & 0.292 & 0.015 & -0.217 \\
\hline X25 & 0.505 & 0.443 & 0.239 & 0.301 & 0.349 & -0.045 & -0.111 \\
\hline X26 & 0.452 & 0.598 & 0.110 & 0.283 & 0.001 & -0.205 & 0.327 \\
\hline
\end{tabular}




\begin{tabular}{rrrrrrrr} 
X27 & 0.123 & 0.024 & 0.700 & -0.273 & 0.040 & 0.033 & 0.191 \\
X28 & 0.056 & 0.197 & 0.848 & 0.099 & 0.155 & 0.173 & 0.118 \\
X29 & 0.119 & 0.347 & 0.798 & 0.222 & 0.103 & 0.097 & 0.033 \\
X30 & -0.006 & 0.267 & 0.595 & 0.425 & 0.037 & 0.163 & 0.207 \\
X32 & 0.204 & 0.061 & 0.629 & 0.189 & 0.072 & -0.008 & -0.390 \\
\hline
\end{tabular}

Tabel 8.6 menunjukkan nilai bobot faktor (faktor loading) setelah melalui proses rotasi. Bobot masing-masing variabel dapat diinterpretasikan sebagai berikut :

1) $X_{1}$, korelasi antara variabel $X_{1}$ dengan faktor 6 paling besar nilainya $(0.850)$ di antara faktor-faktor lainnya sehingga variabel $\mathrm{X}_{1}$ dimasukkan sebagai komponen faktor 6.

2) $\mathrm{X}_{2}$, juga dimasukkan sebagai komponen faktor 6 karena nilai faktor loading paling besar $(0,826)$ terletak pada faktor 6 .

3) $\mathrm{X}_{3}$, dimasukkan sebagai komponen faktor 1 karena nilai faktor loading paling besar $(0,674)$ terletak pada faktor 1 .

4) $\mathrm{X}_{4}$, variabel ini masuk faktor 1 , karena nilai faktor loading paling besar $(0,505)$ terletak pada faktor 1 .

5) $X_{5}$, variabel ini masuk faktor 1 , karena nilai faktor loading paling besar $(0,573)$ terletak pada faktor 1 .

6) $\mathrm{X}_{6}$, variabel ini masuk faktor 5 , karena nilai faktor loading paling besar $(0,658)$ terletak pada faktor 5 .

7) $X_{7}$, dimasukkan sebagai komponen faktor 5 karena nilai faktor loading paling besar $(0,833)$ terletak pada faktor 5 .

8) $\mathrm{X}_{8}$, merupakan komponen dari faktor 7 karena nilai faktor loading paling besar $(0,793)$ terletak pada faktor 7 .

9) $\mathrm{X}_{9}$, merupakan komponen dari faktor 1 karena nilai faktor loading paling besar $(0,612)$ terletak pada faktor 1 .

10) $X_{10}$, merupakan komponen dari faktor 5 karena nilai faktor loading paling besar $(0,750)$ terletak pada faktor 5 .

11) $X_{11}$, variabel ini masuk faktor 4 , karena nilai faktor loading paling besar $(0,524)$ terletak pada faktor 4 .

12) $X_{12}$, merupakan komponen dari faktor 3 karena nilai faktor loading paling besar $(0,607)$ terletak pada faktor 3 .

13) $\mathrm{X}_{13}$, merupakan komponen dari faktor 1 karena nilai faktor loading paling besar $(0,696)$ terletak pada faktor 1 .

14) $X_{14}$, variabel ini masuk faktor 1 , karena nilai faktor loading paling besar $(0,714)$ terletak pada faktor 1.

15) $X_{15}$, variabel ini masuk faktor 4 , karena nilai faktor loading paling besar $(0,743)$ terletak pada faktor 4 .

16) $X_{16}$, variabel ini masuk faktor 4 , karena nilai faktor loading paling besar $(0,866)$ terletak pada faktor 4 .

17) $X_{17}$, korelasi antara variabel $X_{17}$ dengan faktor 4 paling besar nilainya (0.567) di antara faktor-faktor lainnya sehingga variabel $\mathrm{X}_{17}$ dimasukkan sebagai komponen faktor 4.

18) $\mathrm{X}_{18}$, dimasukkan sebagai komponen faktor 2 karena nilai faktor loading paling besar $(0,783)$ terletak pada faktor 2 . 
19) $X_{19}$, dimasukkan sebagai komponen faktor 2 karena nilai faktor loading paling besar $(0,618)$ terletak pada faktor 2 .

20) $X_{20}$, variabel ini masuk faktor 2 , karena nilai faktor loading paling besar $(0,555)$ terletak pada faktor 2 .

21) $X_{21}$, variabel ini masuk faktor 6 , karena nilai faktor loading paling besar $(0,706)$ terletak pada faktor 6 .

22) $X_{22}$, variabel ini masuk faktor 2 , karena nilai faktor loading paling besar $(0,633)$ terletak pada faktor 2 .

23) $\mathrm{X}_{23}$, dimasukkan sebagai komponen faktor 2 karena nilai faktor loading paling besar $(0,603)$ terletak pada faktor 2 .

24) $X_{24}$, korelasi antara variabel $X_{24}$ dengan faktor 2 paling besar nilainya $(0.625)$ di antara faktor-faktor lainnya sehingga variabel $\mathrm{X}_{24}$ dimasukkan sebagai komponen faktor 2.

25) $X_{25}$, merupakan komponen dari faktor 1 karena nilai faktor loading paling besar $(0,505)$ terletak pada faktor 1 .

26) $X_{26}$, merupakan komponen dari faktor 2 karena nilai faktor loading paling besar $(0,598)$ terletak pada faktor 2 .

27) $X_{27}$, korelasi antara variabel $X_{27}$ dengan faktor 3 paling besar nilainya (0.700) di antara faktor-faktor lainnya sehingga variabel $\mathrm{X}_{27}$ dimasukkan sebagai komponen faktor 3 .

28) $\mathrm{X}_{28}$, merupakan komponen dari faktor 3 karena nilai faktor loading paling besar $(0,848)$ terletak pada faktor 3 .

29) $X_{29}$, korelasi antara variabel $X_{29}$ dengan faktor 3 paling besar nilainya (0.796) di antara faktor-faktor lainnya sehingga variabel $\mathrm{X}_{29}$ dimasukkan sebagai komponen faktor 3.

30) $X_{30}$, variabel ini masuk faktor 3 , karena nilai faktor loading paling besar $(0,595)$ terletak pada faktor 3 .

31) $X_{32}$, variabel ini masuk faktor 3, karena nilai faktor loading paling besar $(0,6298)$ terletak pada faktor 3 .

Dari 31 variabel, dihasilkan 7 faktor hasil ekstraksi variabel dengan interpretasi sebagai berikut :

Faktor 1 terdiri dari variabel $\mathrm{X}_{3}, \mathrm{X}_{4}, \mathrm{X}_{5}, \mathrm{X}_{9}, \mathrm{X}_{13}, \mathrm{X}_{14}$, dan $\mathrm{X}_{25}$. Faktor 1 ini dinamakan faktor ekonomi dan budaya. Karena nilai korelasi (bobot faktor) semua variabel bernilai positif berarti semakin besar tanggungjawab responden terhadap keluarga maka semakin membuat responden tertarik menjadi TKW dalam hal ini sebagai korban perdagangan manusia. Perempuan mempunyai peran dalam keluarga. Tanggung jawab yang besar dalam menghidupi keluarga yang membutuhkan uang yang tidak sedikit sehingga dapat menjadi pemicu terjadinya perdagangan manusia.

Faktor 2 terdiri dari variabel $\mathrm{X}_{18}, \mathrm{X}_{19}, \mathrm{X}_{20}, \mathrm{X}_{22}, \mathrm{X}_{23}, \mathrm{X}_{24}$, dan $\mathrm{X}_{26}$. Faktor 2 dinamakan faktor kesempatan kerja dan penghasilan. Karena nilai korelasi (bobot faktor) semua variabel bernilai positif maka semakin sulit responden mendapat pekerjaan yang layak maka semakin membuat responden tertarik menjadi TKW dalam hal ini sebagai korban perdagangan manusia. Berlatar belakang pendidikan yang hanya tamat SD, SMP ataupun SMA menyebabkan mereka kesulitan mendapatkan pekerjaan yang layak. Kondisi ini membuat para korban menerima pekerjaan apapun yang ditawarkan yang penting mendatangkan uang. 
Faktor 3 terdiri dari variabel $\mathrm{X}_{12}, \mathrm{X}_{27}, \mathrm{X}_{28}, \mathrm{X}_{29}, \mathrm{X}_{30}$, dan $\mathrm{X}_{32}$. Faktor 3 ini dinamakan faktor pernikahan dini. Karena nilai korelasi (bobot faktor) semua variabel bernilai positif maka semakin muda usia responden saat menikah maka semakin membuat responden tertarik menjadi TKW dalam hal ini sebagai korban perdagangan manusia. Dalam keluarga anak perempuan seringkali menjadi beban ekonomi keluarga sehingga salah satu jalan untuk mengurangi beban adalah menikahkan anak pada usia dini. Mengawinkan anak dalam usia dini berpotensi menyebabkan kegagalan pernikahan yang bermuara pada kesulitan menghidupi diri sendiri dan juga anak hasil perkawinannya.

Faktor 4 terdiri dari variabel $X_{11}, X_{15}, X_{16}$, dan $X_{17}$. Faktor 4 ini dinamakan faktor rendahnya pendidikan. Karena nilai korelasi (bobot faktor) semua variabel bernilai positif maka semakin rendah tingkat pendidikan responden maka semakin membuat responden tertarik menjadi TKW dalam hal ini sebagai korban perdagangan manusia. Sebagian besar korban human trafficking adalah mereka yang berpendidikan SD atau SMP bahkan ada pula yang putus sekolah. Rendahnya pendidikan mengakibatkan keterbatasan wawasan berpikir sehingga mudah dipengaruhi dan ditipu.

Faktor 5 terdiri dari variabel $\mathrm{X}_{6}, \mathrm{X}_{7}$, dan $\mathrm{X}_{10}$. Faktor ini dinamakan faktor kemiskinan. Karena nilai korelasi (bobot faktor) semua variabel bernilai positif maka semakin responden mempunyai banyak kebutuhan maka semakin membuat responden tertarik menjadi TKW dalam hal ini sebagai korban perdagangan manusia. Kemiskinan telah memaksa banyak keluarga untuk merencanakan strategi penopang kehidupan. Salah satu strategi yang ditempuh adalah bermigrasi untuk bekerja apapun yang penting memperoleh uang.

Faktor 6 terdiri dari variabel $\mathrm{X}_{1}, \mathrm{X}_{2}$, dan $\mathrm{X}_{21}$. Faktor 6 ini dinamakan faktor Kurangnya akses informasi. Karena nilai korelasi (bobot faktor) semua variabel bernilai positif maka semakin kurang pengetahuan responden tentang pekerjaan di luar negeri maka semakin membuat responden mudah menjadi TKW, yaitu sebagai korban perdagangan manusia. Kebanyakan masyarakat korban human trafficking tidak menyadari atau mengetahui ada bahaya perdagangan orang. Artinya mereka tidak mengetahui cara-cara penipuan untuk menjebak mereka dalam pekerjaan-pekerjaan yang mirip perbudakan. Banyaknya masyarakat yang kurang mengetahui bahaya pekerjaan yang digeluti. Sebab yang mereka pikirkan hanyalah jumah penghasilan atau pendapatan yang diterima.

Faktor 7 hanya terdiri dari variabel $\mathrm{X}_{8}$. Faktor 4 ini dinamakan faktor keinginan cepat kaya. Karena nilai korelasi (bobot faktor) semua variabel bernilai positif maka semakin responden mempinyai banyak kebutuhan maka semakin membuat responden tertarik menjadi TKW dalam hal ini sebagai korban perdagangan manusia. Keinginan untuk memiliki materi dan standar hidup yang lebih tinggi memicu terjadinya perdagangan manusia. Kehidupan yang tidak layak dan terhimpit hutang membuat sebagian orang ingin menjadi orang kaya.

Model persamaan yang dihasilkan untuk setiap faktor adalah sebagai berikut :

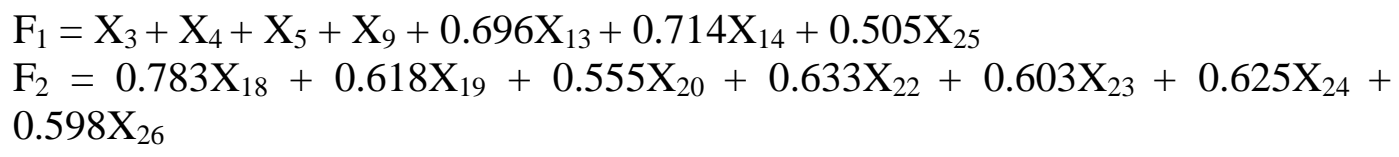




$$
\begin{aligned}
& \mathrm{F}_{3}=0.607 \mathrm{X}_{12}+0.700 \mathrm{X}_{27}+0.848 \mathrm{X}_{28}+0.798 \mathrm{X}_{29}+0.595 \mathrm{X}_{30}+0.629 \mathrm{X}_{32} \\
& \mathrm{~F}_{4}=0.524 \mathrm{X}_{11}+0.743 \mathrm{X}_{15}+0.866 \mathrm{X}_{16}+0.567 \mathrm{X}_{17} \\
& \mathrm{~F}_{5}=0.658 \mathrm{X}_{6}+0.833 \mathrm{X}_{7}+0.750 \mathrm{X}_{10} \\
& \mathrm{~F}_{6}=0.850 \mathrm{X}_{1}+0.826 \mathrm{X}_{2}+0.706 \mathrm{X}_{21} \\
& \mathrm{~F}_{7}=0.793 \mathrm{X}_{8}
\end{aligned}
$$

Ketujuh model yang dihasilkan dapat digunakan untuk analisis lanjutan dengan menghitung skor setiap faktor berdasarkan variabel yang terdapat di setiap faktor.

\section{LATIHAN}

1. Misalkan diketahui ada 3 peubah dengan matriks varian-kovarian sebagai berikut, buktikan bahwa satu faktor dapat terbentuk dari matriks tersbut.

$$
\sum=\left[\begin{array}{ccc}
1 & 0.9 & 0.7 \\
0.9 & 1 & 0.4 \\
0.7 & 0.4 & 1
\end{array}\right]
$$

2. Misalkan ada 5 peubah/variabel dengan nilai matriks korelasi sebagai berikut:

$$
\left[\begin{array}{ccccc}
1 & 0.02 & \underline{0.96} & 0.42 & 0.01 \\
0.02 & 1 & 0.13 & 0.71 & \underline{0.85} \\
0.96 & 0.13 & 1 & 0.50 & 0.11 \\
0.42 & 0.71 & 0.50 & 1 & \underline{0.79} \\
0.01 & 0.85 & 0.11 & 0.79 & 1
\end{array}\right]
$$

dari matriks di atas dapat dikatakan bahwa variabel 1 dan 3, 2 dan 5 dapat membentuk grup karena korelasinya tinggi. Variabel 4 lebih dekat ke grup $(2,5)$ daripada grup $(1,3)$. Misalkan kita tetapkan dengan dua faktor, tentukan dua faktor yang dimaksud. 


\section{BAB IX \\ ANALISIS DISKRIMINAN (DISCRIMINANT ANALYSIS)}

\subsection{PENGANTAR}

Dalam penelitian yang melibatkan banyak variabel, seringkali perlu menentukan pemisahan antar beberapa kelompok dari data yang diperoleh melalui karakteristik-karakteristik tertentu sehingga didapatkan interpretasi dari masingmasing kelompok. Kemudian diidentifikasi jumlah minimum kelompok (dalam hal ini fungsi) tersebut. Misalkan saja dengan melihat gejala-gejala yang tampak pada seseorang, dokter bisa menduga penyakit apa yang diderita orang tersebut. Dengan melihat warna, merasakan dan menghirup asap rokok, penilai bisa mengetahui kelas kualitas tembakau. Sebuah perusahaan asuransi, misalnya, ingin memprediksi apakah seorang nasabah baru akan bertahan terus sesuai dengan program ataukah berhenti membayar polis di tengah jalan sedangkan perusahaan lainnya ingin memprediksi apakah seorang karyawan baru akan memiliki produktivitas tinggi atau tidak. Dan masih banyak kasus-kasus serupa lainnya yang dapat ditemukan di berbagai bidang terapan. Salah satu teknik yang relatif akurat untuk dapat melakukan pemisahan objek seperti kasus di atas adalah analisis diskriminan. Analisis diskriminan merupakan salah satu teknik multivariate yang tujuan utamanya adalah membuat pemisahan beberapa gugus objek yang berasal dari dua atau lebih populasi, serta mengalokasikan suatu objek yang belum diketahui berasal dari populasi yang mana ke dalam gugus yang telah ditentukan batasan sebelumnya. Pengelompokan ini bersifat mutually exclussive, artinya bahwa jika objek A telah dimasukkan ke dalam kelompok 1 maka tidak mungkin juga dimasukkan ke dalam kelompok 2. Analisis kemudian dapat dikembangkan pada variabel mana saja yang membuat kelompok 1 berbeda dengan kelompok 2 , berapa persen yang masuk ke kelompok 1, berapa persen yang masuk ke kelompok 2 dan seterusnya.

Dalam bab ini Anda akan mempelajari konsep dasar analisis diskriminan dan mengetahui kapan analisis diskriminan bisa diterapkan, yang mencakup materimateri bahasan sebagai berikut : Konsep Dasar Analisis Diskriminan, Model Analisis Diskriminan, Klasifikasi dengan Dua Populasi, Klasifikasi dengan Beberapa Populasi, Pendugaan Tingkat Kesalahan Klasifikasi.

\subsection{URAIAN}

\section{A. Konsep Dasar Analisis Diskriminan}

Cara terbaik pemisahan antar kelompok tersebut adalah dengan membentuk sejumlah fungsi melalui kombinasi linier variabel-variabel asal. Analisis diskriminan menghubungkan satu kriteria atau variabel dependen kategorik (berskala ordinal atau nominal) dengan satu atau beberapa variabel independen berskala metrik (interval atau rasio). Selanjutnya, fungsi yang terbentuk melalui analisis ini disebut sebagai fungsi diskriminan, yang dalam prosesnya fungsi diskriminan akan memberikan nilai-nilai yang sedekat mungkin dalam kelompok dan sejauh mungkin antar kelompok. Fungsi diskriminan ini 
digunakan untuk menerangkan perbedaan antar kelompok dan dalam masalah klasifikasi. Jadi, dapat dikatakan bahwa tujuan analisis diskriminan adalah

- Dapat memisahkan antar segmen dengan tegas melalui pembangkitan fungsi diskriminan (pembeda) antar segmen

- Mencari atribut-atribut pembeda utama antar segmen

- Klasifikasi individu baru (resegmentation)

- Untuk mengetahui apakah ada perbedaan yang jelas antara kelompok pada variable dependen? Jika ada perbedaan, variabel independen manakah pada fungsi diskriminan yang membuat perbedaan tersebut.

Namun, kaidah keputusan pengklasifikasian berdasarkan kriteria apapun tidak selalu bisa diharapkan memiliki ketepatan yang sempurna, tetap selalu ada peluang kesalahan klasifikasi (missclassification). Huberty (1994) mengatakan bahwa salah satu permasalahan khusus yang berhubungan dengan analisis diskriminan adalah masalah salah pengelompokan (missclassification) awal pengelompokan. Sewajarnya kesalahan ini yang dikendalikan sehingga bisa dibuat sekecil mungkin.

\section{Gunanya}

1. Menyusun fungsi pembeda antara kelompok 1, kelompok $2, \ldots$, kelompok k. Dengan adanya fungsi tersebut maka akan didapatkan batasan batasan nilai antara kelompok1,..., kelompok $\mathrm{k}$.

2. Fungsi tersebut dapat diketahui tingkat akurasinya (berapa persen kesalahannya).

3. Fungsi tersebut digunakan untuk mengelompokkan anggota baru termasuk ke dalam kelompok mana?

\section{Ilustrasi}

- Dengan melihat gejala-gejala yang nampak pada seseorang, dokter bisa menduga penyakit apa yang diderita orang tersebut.

- Dengan melihat warna, merasakan, dan menghirup asap rokok, penilai bisa mengetahui kelas kualitas tembakau.

- Dengan mengetahui berbagai indikator yang berupa variabel derivatif keuangan sebuah bank, kita bisa menilai kesehatan bank tersebut.

\section{Fungsi Diskriminan}

- Merupakan kombinasi dari beberapa peubah, satu peubah saja umumnya tidak mencukupi

- Dari banyak peubah, menggunakan fungsi diskriminan diperoleh sebuah indeks

- Berdasarkan kriteria tertentu, dengan indeks ini kita mengklasifikasikan objek

- Tidak selalu (bahkan jarang) diperoleh fungsi diskriminan dengan tingkat ketepatan yang sempurna

- Fungsi Diskriminan memiliki ukuran yang menggambarkan tingkat ketepatan

Andaikan ada $k$ buah populasi berbeda, yaitu $\prod_{1}, \ldots, \prod_{k}$ dan fungsi kepekatan peluang dari vektor berukuran $p$ x 1 pada populasi ke- $i$ adalah $f_{i}(\mathbf{x})$. Kemudian kita bayangkan bahwa ruang berdimensi $p$ kita sekat-sekat menjadi $k$ daerah yang saling lepas, yaitu $D_{1}, \ldots, D_{k}$. Suatu pengamatan acak $\mathbf{x}$ akan diklasifikasikan sebagai anggota populasi $\prod_{t}$ jika $\mathbf{x}$ berada pada daerah $D_{t}$. Dengan aturan seperti ini, jelas bahwa setiap objek pengamatan akan 
dikelompokan kepada hanya salah satu populasi dari $k$ populasi yang ada. Namun ada kemungkinan bahwa objek yang semestinya merupakan anggota populasi $\prod_{\mathrm{s}}$ diklasifikasikan menjadi anggota populasi $\prod_{t}$, dengan demikian kesalahan klasifikasi bisa terjadi dalam $k(k-1)$ cara yang berbeda. Peluang suatu objek yang berasal dari $\prod_{s}$ diklasifikasikan kepada populasi $\prod_{t}$ dinyatakan sebagai peluang besyarat :

$$
\mathrm{P}(t \mid s)=\mathrm{P}\left(x \in D_{t} \mid x \in \prod_{\mathrm{s}}\right), s \neq t
$$

Pengklasifikasian yang bagus memiliki peluang salah klasifikasi yang minimal, yang akan terjadi jika daerah-daerah $D_{1}, \ldots, D_{k}$ terpisah secara tegas. Inilah tujuan utamanya, yaitu mencari aturan klasifikasi atau aturan pembuatan indeks sehingga mampu memisahkan $D_{1}, \ldots, D_{k}$ setegas mungkin satu sama lain. Sebagai catatan juga bahwa pembuatan aturan klasifikasi ini juga sangat tergantung pada seberapa jauh pemisahan antara $\prod_{1}, \ldots, \prod_{\mathrm{k}}$.

\section{B. Model Analisis Diskriminan}

Model dasar analisis diskriminan mirip dengan regresi berganda, yaitu sebuah persamaan yang menunjukkan kombinasi linier dari berbagai variabel bebas :

$\mathrm{Z}=$ skor diskriminan

$$
\mathrm{Z}=b_{0}+b_{1} \mathrm{X}_{1}+\ldots+b_{k} \mathrm{X}_{k}
$$

$b_{\mathrm{i}}=$ koefisien diskriminan atau bobot

$\mathrm{X}=$ prediktor atau variabel takbebas

Yang diestimasi adalah koefisien $b$ sehingga nilai $\mathrm{Z}$ setiap kelompok sedapat mungkin berbeda. Berdasarkan nilai Z itulah keanggotaan suatu objek diprediksi.

\section{Klasifikasi dengan Dua Populasi}

\section{Pendekatan Fisher}

R. A. Fisher bekerja untuk mendapatkan fungsi diskriminan pada kasus yang terdiri atas hanya dua populasi $(k=2)$ melalui pencarian suatu fungsi linier sedemikian rupa sehingga kedua populasi terpisah sejauh mungkin. Dalam hal ini diasumsikan kedua populasi memiliki matriks ragam-peragam yang sama.

Bisa dituliskan sebagai berikut : Cari a yang memaksimumkan jarak antara $\mathrm{E}\left(\mathbf{a}^{\prime} \mathbf{x}\right)=\mathbf{a} \boldsymbol{\mu}_{1}$ di $\prod_{1}$ dengan $\mathrm{E}\left(\mathbf{a}^{\prime} \mathbf{x}\right)=\mathbf{a} \boldsymbol{\prime}_{2}$ di $\Pi_{2}$ atau

maksimumkan $\left|\mathbf{a}^{\prime} \boldsymbol{\mu} 1-\mathbf{a} \boldsymbol{\mu}_{2}\right|$ dengan kendala $\mathbf{a} \boldsymbol{} \boldsymbol{\Sigma} \mathbf{a}=1$, dimana $\mathbf{a}=\boldsymbol{\Sigma}^{-1}\left(\boldsymbol{\mu}_{1}-\boldsymbol{\mu}_{2}\right)$ Aturannya adalah alokasikan $\mathbf{x}$ ke $\prod_{1}$ jika $\mathbf{a}^{\prime} \mathbf{x} \geq \mathrm{h}$, dan sebaliknya masukkan $\mathbf{x}$ kedalam $\prod_{2}$, dimana $h=1 / 2 \mathbf{a}^{\prime}\left(\boldsymbol{\mu}_{1}+\boldsymbol{\mu}_{2}\right)$.

Dengan perkataan lain, $\mathbf{x}$ akan dimasukkan ke populasi yang paling dekat dengannya.

\section{Klasifikasi dengan Cara Lain}

Cara lain untuk melakukan klasifikasi adalah menggunakan konsep jarak terhadap vektor rataan populasi yang paling dekat. Jika ada suatu pengamatan/objek baru $\mathbf{x}=\left(x_{1}, x_{2}\right)$, maka pengamata ini akan dimasukkan kedalam populasi ke-1 $\left(\Pi_{1}\right)$ hanya jika jarak $\mathbf{x}$ terhadap $\overline{\mathbf{x}}_{1}$ (vektor rataan populasi ke-1) lebih dekat dibandingkan $\mathrm{ke} \overline{\mathbf{x}}_{2}$. Rumus jarak yang digunakan adalah jarak mahalanobis, yatu: 


$$
\mathrm{d}_{j}(\mathbf{x})=\left\{\left(\mathbf{x}-\overline{\mathbf{x}}_{j}\right)^{\prime} \mathbf{S}^{-1}\left(\mathbf{x}-\overline{\mathbf{x}}_{j}\right)\right\}^{1 / 2}
$$

Pendekatan lain juga dapat digunakan dengan menggunakan peluang posterior. Suatu pengamatan/objek baru $\mathbf{x}=\left(x_{1}, x_{2}\right)$ akan dimasukkan kedalam $\prod_{1}$ hanya jika peluang posteriornya lebih besar dibandingkan masuk kedalam $\prod_{2}$. Peluang posterior masuk ke dalam $\prod_{j}$ adalah

$$
P(j \mid x)=\frac{\exp \left(-\frac{1}{2} d_{j}^{2}(x)\right)}{\exp \left(-\frac{1}{2} d_{1}^{2}(x)\right)+\exp \left(-\frac{1}{2} d_{2}^{2}(x)\right)}
$$

\section{Klasifikasi dengan Parameter Diketahui}

$$
\text { Katakan } \mathbf{x} \text { mempunyai fkp } \mathrm{f}_{1}\left(\mathbf{x}, \theta_{1}\right) \text { dan } \mathrm{f}_{2}\left(\mathbf{x}, \theta_{2}\right) \text {, maka } \lambda=\frac{f_{1}\left(\mathbf{x}, \theta_{1}\right)}{f_{2}\left(\mathbf{x}, \theta_{2}\right)}
$$

$\mathbf{x}$ sebagai kelompok 1 jika $\lambda>1$ dan $\mathbf{x}$ masuk ke kelompok 2 jika $\lambda<1$.

Katakan suatu fungsi dengan $\mathrm{p}$-variabel dengan fkp multivariate normal dengan matriks kovariance $\sum$ dan vektor rataan $\mathbf{u}_{1}$ dan $\mathbf{u}_{2}$

Maka $\lambda=\exp \left[\left(\mathbf{u}_{1}-\mathbf{u}_{2}\right), \sum^{-1} \mathbf{x}-1 / 2\left(\mathbf{u}_{1}-\mathbf{u}_{2}\right)^{\prime} \sum^{-1}\left(\mathbf{u}_{1}+\mathbf{u}_{2}\right)\right]$

$\mathbf{x}$ ada suatu dan dari kelompok 1 jika

$$
\left(\mathbf{u}_{1}-\mathbf{u}_{2}\right), \sum^{-1} \mathbf{x}-1 / 2\left(\mathbf{u}_{1}-\mathbf{u}_{2}\right), \sum^{-1}\left(\mathbf{u}_{1}+\mathbf{u}_{2}\right)>0
$$

dan sebaliknya adalah populasi 2 .

\section{Klasifikasi dengan Beberapa Populasi}

Misalkan terdapat $k(\geq 2)$ populasi yang masing-masing mengikuti sebaran normal ganda. Yang diinginkan adalah diperolehnya aturan klasifikasi untuk waktu berikutnya bagi suatu pengamatan yang identitasnya tidak diketahui dan ingin dimasukkan ke dalam salah satu dari $k$ populasi tersebut. Karena pada situasi tertentu ada kemungkinan yang paling besar suatu objek berasal dari populasi tertentu, sehingga logis jika ada peluang prior $p_{i}$ bahwa objek tersebut berasal dari populasi ke-i, dimana $\sum_{i=1}^{k} p_{i}=1$. Dengan demikian ECM (expected cost of misclassification) sebagai salah satu kriteria untuk memperoleh aturan klasifikasi dirumuskan sebagai berikut:

$$
\sum_{t=1}^{k} p_{t} \sum_{\substack{s=1 \\ s \neq t}}^{k} \mathrm{P}(s \mid t) \mathrm{C}(s \mid t)
$$

Dengan kriteria minimum ECM ditentukan aturan pengalokasian objek/pengamatan baru $\mathbf{x}_{0}$, yaitu alokasikan $\mathbf{x}_{0}$ ke $\prod_{\mathrm{t}}$ jika $p_{\mathrm{t}} f_{\mathrm{t}}(\mathbf{x})>p_{\mathrm{s}} f_{\mathrm{s}}(\mathbf{x})$ untuk semua $\mathrm{s} \neq \mathrm{t}$.

\section{Fungsi Diskriminan Linier}

Jika $k$ populasi memiliki matriks koragam yang sama, yaitu $\sum$ dan biaya salah klasifikasi diasumsikan sama besar, maka aturan yang paling sederhana pada klasifikasi dinyatakan dalam fungsi kuadrat jarak yaitu

$$
\mathrm{d}_{t}(\mathbf{x})=\left(\mathbf{x}-\boldsymbol{\mu}_{\mathrm{t}}\right)^{\prime} \Sigma^{-1}\left(\mathbf{x}-\boldsymbol{\mu}_{\mathrm{t}}\right)-2 \ln \left(p_{t}\right)
$$


Suatu objek $\mathbf{x}$ diklasifikasikan kepada populasi yang terdekat, atau $\mathbf{x}$ akan diklasifikasikan berasal dari populasi ke-t jika

$$
\mathrm{d}_{t}^{2}(\mathbf{x})=\min \left\{\mathrm{d}_{j}^{2}(\mathbf{x})\right\} ; j=1, \ldots, k .
$$

Seperti halnya pada bagian terdahulu, mengklasifikasikan objek pengamatan ke populasi yang terdekat setara dengan mengklasifikasikan objek ke populasi dengan peluang posterior yang paling besar. Pada kasus $\mathrm{k}$ buah populasi, peluang tersebut besarnya diperoleh dari

$$
\mathrm{P}(t \mid \mathbf{x})=\frac{\exp \left(-\frac{1}{2} d_{t}^{2}(\mathbf{x})\right)}{\sum_{j=1}^{k} \exp \left(-\frac{1}{2} d_{j}^{2}(\mathbf{x})\right)}, \quad t=1,2, \ldots, k
$$

dimana total dari peluang posterior adalah 1

\section{Fungsi Diskriminan Kuadratik}

Pada kasus ini, aturan klasifikasi akan tergantung pada matriks koragam masingmasing, yaitu $\sum_{1}, \sum_{2}, \ldots, \sum_{k}$. Suatu objek pengamatan $\mathbf{x}$ akan dimasukkan ke populasi ke-t jika

$$
\mathrm{d}_{t}^{2}(\mathbf{x})=\min \left\{\mathrm{d}_{j}(\mathbf{x})\right\} ; j=1, \ldots, k
$$

$\operatorname{dimana} \mathrm{d}_{j}^{2}(\mathbf{x})=\left(\mathbf{x}-\boldsymbol{\mu}_{\mathrm{j}}\right)^{\prime} \Sigma^{-1}\left(\mathbf{x}-\boldsymbol{\mu}_{\mathrm{j}}\right)+\ln |\Sigma|-2 \ln \left(p_{j}\right)$

\section{E. Pendugaan Tingkat Kesalahan Klasifikasi}

\section{Pendugaan Tingkat Kesalahan dengan Validasi Silang}

- jika ada $n$ objek pengamatan, maka hanya $(n-1)$ pengamatan yang digunakan sebagai gugus data pembentukan fungsi diskriminan

- satu pengamatan sisanya digunakan untuk evaluasi

- proses di atas diulang sebanyak n kali, satu kali untuk setiap data yang disisihkan

- proporsi kesalahan adalah dugaan tingkat kesalahan

\section{F. ILUSTRASI}

1. Penelitian ini dilakukan di Provinsi NTT dengan mengambil sampel dari beberapa kabupaten. Tujuan penelitian ini adalah membuat model diskriminan dari bentuk-bentuk kasus Human trafficking di NTT (Geradus Dkk 2019):

\section{Analisis Diskriminan}

\section{Menguji kehomogenan rata-rata kelompok}

\section{Tabel 9.2 Tests of Equality of Group Means}

\begin{tabular}{lrrrrr}
\hline & $\begin{array}{c}\text { Wilks' } \\
\text { Lambda }\end{array}$ & F & df1 & df2 & Sig. \\
\hline Ekonomi dan budaya (X1) & 0.802 & 14.355 & 1 & 58 & $0.000^{*}$ \\
Kesempatan kerja dan penghasilan (X2) & 0.996 & 0.236 & 1 & 58 & 0.629 \\
Pernikahan dini (X3) & 0.886 & 7.476 & 1 & 58 & $0.008^{*}$
\end{tabular}




\begin{tabular}{llllll} 
Pendidikan rendah (X4) & 0.992 & 0.472 & 1 & 58 & 0.495 \\
Kemiskinan (X5) & 0.924 & 4.774 & 1 & 58 & $0.033^{*}$ \\
Kurangnya akses informasi (X6) & 0.904 & 6.186 & 1 & 58 & $0.016^{*}$ \\
Keinginan menjadi cepat kaya (X7) & 0.949 & 3.110 & 1 & 58 & 0.083 \\
\hline
\end{tabular}

*) signifikan pada $\alpha=0.05$

Dari Tabel 9.2 menunjukkan bahwa dari ketujuh variabel bebas, ada tiga variabel yang nilai signifikansinya di atas 0.05 yaitu variabel Kesempatan kerja dan penghasilan (X2), Pendidikan rendah (X4), dan Keinginan menjadi cepat kaya (X7). Sedangkan keempat variabel bebas yaitu Ekonomi dan budaya (X1), Pernikahan dini (X3), Kemiskinan (X5), dan Kurangnya akses informasi (X6)mempunyai nilai signifikansi di bawah 0.05. Artinya keempat variabel bebas tersebut adalah variabel yang membedakan kedua kelompok Perdagangan orang (Human trafficking), dalam hal ini kelompok Perdagangan Anak ( $\mathrm{Y}_{1}$ ) dan kelompok Buruh Imigran Internasional $\left(\mathrm{Y}_{2}\right)$. Dapat pula diartikan bahwa faktorEkonomi dan budaya, Pernikahan dini, Kemiskinan, dan Kurangnya akses informasi mempengaruhi TKI menjadi korban Perdagangan Orang.

Secara detail dapat dijelaskan bahwa :

- Variabel X1, nilai signifikansinya adalah 0.000, artinya ada perbedaan antara responden kelompok perdagangan anak dengan kelompok buruh imigran terkait faktor ekonomi dan budaya. Pandangan masyarakat setempat memiliki kebiasan menempatkan wanita di bawah laki-laki. Dalam kehidupan sehari-hari, laki-laki diprioritaskan dalam kehidupan sehari-hari seperti laki-laki diprioritaskan dalam makan dan dalam pendidikan. Makanan diprioritaskan untuk kaum laki-laki sedangkan kaum perempuan menunggu sisa makanan dari kaum perempuan. Begitu pula dalam hal pendidikan. Untuk mengenyam pendidikan, para laki-laki terlebih dahulu diberi kesempatan. Apabila laki-laki tidak memenafaatkan kesempatan yang diberikan barulah kesempatan itu disodorkan ke perempuan. Budaya patriarki ini yang membedakan responden menjadi korban human trafficking kelompok perdagangan anak dan kelompok buruh imigran. Selain factor budaya, factor ekonomi juga sebagai pembeda responden memilih menjadi perdagangan anak dan buruh imigran. Uang menjadi motivasi terbesar bagi sebagian besar responden menjadi korban perdagangan manusia dan buruh anak. Kehidupan serba kekurangan dalam berbagai kebutuhan hidup menjadi korban human trafficking. Kemiskinan dan penganguran menjadi faktor terbesar perdagangan manusia dalam sistem internasional (Majeed A. Rahman, 2011. Human Trafficking in the Era of Globalization: The Case of Trafficking in the Global Market Economy, (Vol. 2, No. 1, 2011), 65. Harapan mendapatkan kehidupan yang lebih baik namun memiliki keterampilan kerja yang sangat minim membedakan responden menjadi buruh imigran atau perdagangan anak.

- Variabel X3, nilai signifikansinya adalah 0.008. Nilai ini menunjukkan terdapat perbedaan antara responden kelompok perdagangan anak dengan kelompok buruh imigran terkait faktor pernikahan dini. Beban ekonomi pada keluarga sering kali mendorong orang tua untuk cepat-cepat 
menikahkan anaknya dengan harapan beban ekonomi keluarga akan berkurang, karena anak perempuan yang sudah nikah menjadi tanggung jawab suami. Anak yang menikah di usia dini kadang tidak memahami hak dan kewajibannya sebagai suami istri karena ketidaksiapan mental dan fisik. Fisik yang mental yang belum matang dan benar-benar siap menghadapi kehidupan setelah menikah dapat menyebabkan perceraian. Dari responden diketahui bahwa banyak dari mereka terpaksa bercerai karena suami yang tidak bertanggungjawab. Sebagian responden melakukan pernikahan dibawah umur 20 tahun dan berakhir dengan suami yang pergi dari rumah dan tidak bertangungjawab atas kehidupan mereka. Rumah tangga ini pada umumnya bertahan bertahan paling lama 2 tahun. Hal ini menjadi akar masalah perdagangan orang. Ketidakberdayaan ketika menjadi orangtua tua tunggal ataupun beban social karena ditinggal suami menjadi factor pembeda responden memilih menjadi buruh imigran dan perdagangan anak. Mereka yang berusia di atas 20 tahun memilih menjadi buruh imigran namun mereka yang berusia dibawah 20 tahun disebut sebagai perdagangan anak.

- Variabel X5, nilai signifikansinya adalah 0.033, artinya ada perbedaan antara responden kelompok perdagangan anak dengan kelompok buruh imigran jika dilihat dari faktor kemiskinan. Menurut Emilia Julia (Tribun News, 7 September 2019), di Provivnsi NTT dalam kurun waktu Januari sampai Fevruari 2018 terdapat 13 menjadi korban kejahatan perdagangan orang. Kemiskinan merupakan factor penentu terjadinya kejahatan ini. Pada umumnya perempuan yang langsung merasakan dampak dari kemiskinan ini. Solusi yang ditempuh para perempuan adalah mencari pekerjaan di luar kampung halamannya. Kemiskinan merupakan suatu kondisi ketidakmampuan mencukupi kebutuhan pokok sehingga mengalami kesulitan melangsungkan kehidupan. Berdasarkan Undang_undang No 24 Tahun 2004, kemiskinan adalah kondisi social ekonomi seseorang atau sekelompok orang yang tidak terpenuhinya hakhak dasarnya untuk mempertahankan dan mengembangkan kehidupan yang bermartabat. Ketidakberdayaan dalam ekonomi memenuhi kebutuhan diri sendiri dan keluarga menjadi aspek yang membedakan para korban perdagngan orang memilih menjadi buruh imigran atau perdagangan anak. Bagi perempuan yang berusia dibawah 18 tahun namun tidak memiliki keterampilan kerja yang memadai akan memilih menjadi buruh anak. Pada umumnya cara berpikir perempuan dibawah 18 tahun berorientasi pada memiliki barang-barang mewah tapi tidak dengan pekerjaan yang berat. Sedangkan mereka yang berusia di atas 18 tahun memiliki keinginan untuk memperbaiki ekonomi rumah tangga dan membangun rumah. Hal ini yang membuat mereka lebih memilih menjadi buruh imigran.

- Variabel X6, nilai signifikansinya adalah 0.008, artinya ada perbedaan antara responden kelompok perdagangan anak dengan kelompok buruh imigran terkait faktor kurangnya akses informasi. Kekurangan pengetahuan karena tidak mendapatkan informasi mengenai resiko dan dampak dari sebagai pekerja buruh imigran maupun buruh anak. Selain akses informasi berkaitan dengan perdagangan orang, perbedaan akses 
pendidikan ini membuat perempuan tidak mempunyai kemampuan, kapasitas dan keterampilan yang bagus ketika memasuki dunia kerja. Akibatnya mereka terjebak dalam perdagangan orang dengan iming-iming gaji besar. Mereka tidak memahami prosedur menjadi tenaga kerja dan syarat-syaratnya. Salah satu syarat resmi adalah batas usia. Syarat ini yang kadang menjadi alasan utama mereka memilih menjadi buruh imigran atau perdagangan anak.

Dari tujuh variabel, ada empat variabel yang berbeda secara nyata pada dua kelompok Perdagangan Orang yaitu Ekonomi dan budaya, Pernikahan dini, Kemiskinan, dan Kurangnya akses informasi.Sehingga responden menjadi korban perdagangan anak maupun buruh imigran internasional disebabkan karena faktor Ekonomi dan budaya, Pernikahan dini, Kemiskinan, dan Kurangnya akses informasi.

Meskipun ada beberapa variabel yang tidak nyata namun variabel-variabel tersebut tetap dimasukkan ke dalam pengujian diskriminan karena dianggap bahwa semua variabel dalam analisis multivariat adalah satu kesatuan.

\section{Menguji kehomogenan varians/ragam}

Jika hasil anova dan angka Wilk's Lambda menguji means (rata-rata) setiap variabel, maka Box's M menguji varians setiap variabel. Dalam analisis Diskriminan, diasumsikan bahwa :

1. Varian variabel bebas untuk tiap grup adalah homogen. Artinya, varian dari responden korban perdagangan anak sama dengan varian responden buruh imigran.

2. Varian di antara variabel-variabel bebas juga seharusnya sama, atau dengan kata lain bahwa ada kehomogenan ragam antara variabel Ekonomi dan budaya (X1), Kesempatan kerja dan penghasilan (X2), Pernikahan dini (X3), Pendidikan rendah (X4), Kemiskinan (X5), Kurangnya akses informasi (X6), dan Keinginan menjadi cepat kaya (X7).

Kedua teori di atas dapat dibuktikan dengan melakukan uji hipotesis sebagai berikut :

$\mathrm{H}_{0}=$ matriks kovarians kelompok adalah sama

$\mathrm{H}_{1}=$ matriks kovarians kelompok adalah berbeda

Jika nilai signifikansinya $>0.05$ maka $\mathrm{H}_{0}$ diterima, jika sebaliknya maka $\mathrm{H}_{0}$ ditolak.

Dalam menguji kehomogenan ragam, digunakan nilai Box's $\mathrm{M}$ dengan aturan sebagai berikut :

Tabel 9.3 Tests Box's M

\begin{tabular}{cr}
\hline Box's M & 33.003 \\
F Approx. & 1.026 \\
df1 & 28 \\
df2 & $1.161 \mathrm{E} 4$ \\
Sig. & 0.427 \\
\hline
\end{tabular}


Dari Tabel 8.3 terlihat bahwa angka sig. $=0.427>0.05$, sehingga $\mathrm{H}_{0}$ diterima, berarti matriks kovarians kelompok adalah sama. Ini berarti bahwa analisis diskriminan layak dilakukan untuk data ini.

\section{Menganalisis ringkasan fungsi-fungsi diskriminan kanonis}

Tabel 8.4 Variables in the Analysis

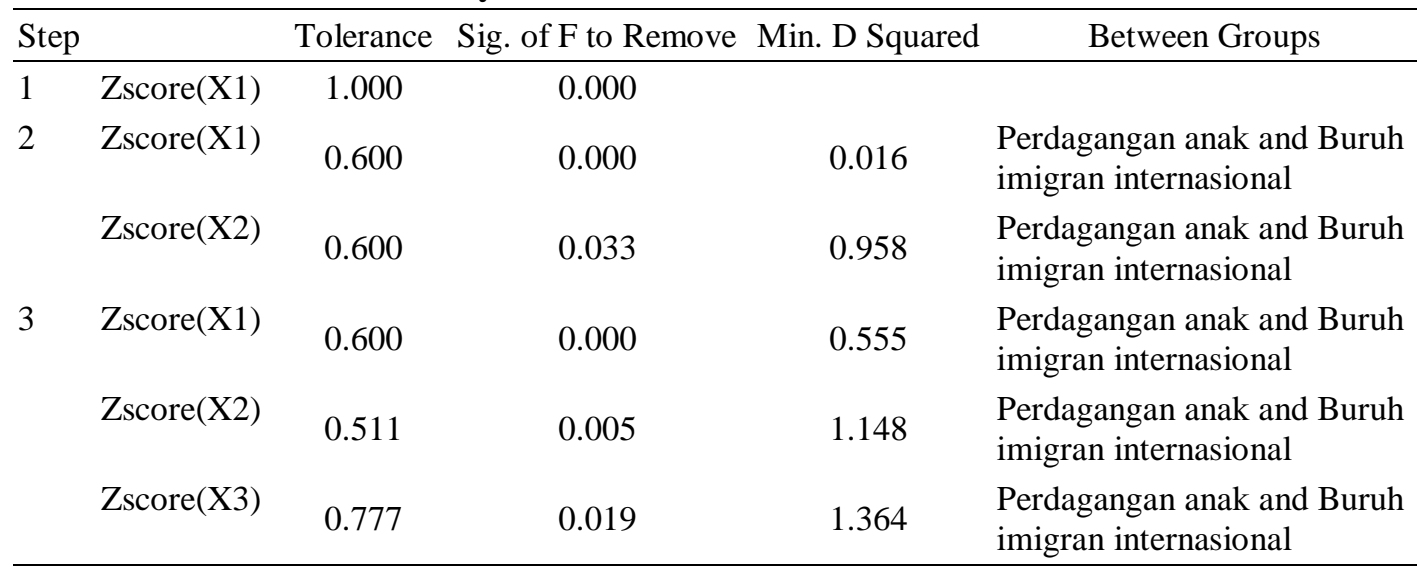

Setelah melewati metode stepwise (Tabel 9.4), dari ketujuh variabel yang dimasukkan untuk membuat model diskriminan, hanya tiga variabel yang signifikan yaitu variabel Ekonomi dan budaya (X1), Kesempatan kerja dan penghasilan (X2) serta Pernikahan dini (X3). Hal ini diartikan bahwa dua bentuk perdagangan orang yang ada di NTT terjadi karena adanya faktor ekonomi dan budaya, Kesempatan kerja dan penghasilan serta Pernikahan dini.

\section{Tabel 9.5 Eigenvalues}

\begin{tabular}{rrrrr}
\hline Function Eigen value & $\%$ of Variance & Cumulative $\%$ & $\begin{array}{c}\text { Canonical } \\
\text { Correlation }\end{array}$ \\
\hline 1 & 0.493 & 100 & 100 & 0.575 \\
\hline
\end{tabular}

Pada Tabel 9.5 tertera nilai eigen dan besarnya varians dari fungsi diskriminan yang terbentuk. Untuk model diskriminan, nilai eigen (eigen value) sebesar 0.493 dengan varians $100 \%$. Hal ini menujukkan bahwa fungsi diskriminan telah mampu melakukan pengelompokan dengan akurat.

Begitu pula jika kita melihat nilai korelasi kanonik pada Tabel 5.5.Korelasi kanonik mengukur keeratan hubungan antara skor diskriminan dengan kelompok (Perdagangan anak dan Buruh imigran internasional).Untuk fungsi ini nilai korelasi kanoniknya yaitu sebesar 0.575 , ini menunjukkan bahwa ada korelasi yang kuat antara skor fungsi diskriminan dengan kelompok, yang berarti bahwa variabel bebas yang digunakan dalam fungsi diskriminan dapat mendiskriminasikan/membedakan objek ke dalam kelompok.

Berdasarkan Tabel 9.6 terlihat bahwa nilai signifikansi Wilks Lambda untuk fungsi diskriminan sebesar 0.000 atau bisa dikatakan sangat signifikan.Ini menunjukkan bahwa variabel bebas mempunyai pengaruh yang signifikan terhadap kelompok objek atau menunjukkan perbedaan yang jelas antara kedua kelompok responden (perdagangan anak dan buruh imigran) berdasarkan variabel 
Ekonomi dan budaya $\left(\mathrm{X}_{1}\right)$, Kesempatan kerja dan penghasilan $\left(\mathrm{X}_{2}\right)$, Pernikahan $\operatorname{dini}\left(\mathrm{X}_{3}\right)$.

Tabel 9.6 Wilks' Lambda

\begin{tabular}{lrrrr}
\hline Test of Function(s) & Wilks' Lambda & Chi-square & df & \multicolumn{1}{l}{ Sig. } \\
\hline 1 & 0.670 & 22.660 & 1 & 0.000 \\
\hline
\end{tabular}

Tabel 9.7 Structure Matrix

\begin{tabular}{ll}
\hline & Function \\
\cline { 2 - 2 } & 1 \\
\hline$X_{1}$ & 0.708 \\
\hline$X_{2}$ & 0.091 \\
\hline$X_{3}$ & 0.511 \\
\hline
\end{tabular}

Tabel struktur matriks (Tabel 9.7) menjelaskan korelasi antara variabel bebas dengan fungsi diskriminan yang terbentuk. Terlihat bahwa variabel Ekonomi dan budaya $\left(\mathrm{X}_{1}\right)$ merupakan variabel yang mempunyai korelasi paling tinggi dengan fungsi diskriminan yang terbentuk, dan korelasi tertinggi berikutnya adalah variabel Pernikahan dini $\left(\mathrm{X}_{3}\right)$ kemudian yang paling kecil korelasinya dengan fungsi Diskriminan adalah variabel Kesempatan kerja dan penghasilan $\left(\mathrm{X}_{2}\right)$.

Pada umumnya mereka yang menjadi korban perdagangan orang adalah mereka yang memiliki ekonomi lemah. Pendidikan rendah membuat mereka tidak memiliki pengetahuan dan keterampilan untuk mendapatkan pekerjaan yang layak. Korban dengan latar belakang ekonomi yang kurang baik biasanya pertumbuhan sosialnya kurang baik pula. Kondisi ini dapat mempengaruhi gaya hidup yang terwujud dalam keinginan menjadi oarng yang berkecukupan dalam segi ekonomi. Pergaulan dalam lingkungan orang-orang yang mampu memenuhi segala kebutuhan mereka, membuat korban terobsesi untuk bekerja memenuhi kebutuhan hidupnya yang selama ini tidak terpenuhi karena kondisi orangtua atau rumah tangganya. Himpitan kehidupan menyebabkan korban mencari solusi melalui berbagai upaya memenuhi kebutuhan tanpa memikirkan resiko dari jalan yang mereka tempuh. Keinginan untuk mendapatkan uang dengan mudah, membuat mereka mencari dan menerima pekerjaan apapun tanpa melihat resiko dari pekerjaan tersebut.Factor ekonomi disebabkan juga oleh rendahnya pendidikan.Korban hanya mengenyam pendidikan SD atau SMP sulit mendapatkan pekerjaan yang memenuhi kebutuhan hidupnya.

Sebagian besar masyarakat Provinsi NTT menganut budaya patriarki.Sistem social yang menempatkan laki-laki sebagai pemegang kekuasan utama dan mendominasi terhadap perempuan, anak-anak dan harta menjadi salah satu penyebab utama terjadinya perdagangan orang. Dominasi laki-laki terhadap perempuan tidak menjadi ancaman keberadaan perempuan apabila pada perempuan tidak terjadi kerugian psikis, material maupun fisik.Dominasi laki-laki dalam mendapatkan pendidikan yang layak menyebabkan perempuan kurang bahkan tidak mendapat kesempatan untuk mengenyam pendidikan yang lebih 
tinggi.Selain itu, dalam hal makanan sehari-hari, pada umumnya laki-laki terlebih dahulu makan sehingga perempuan dan anak-anak kurang mendapat makanan yang bergizi. Pada beberapa daerah di Provinsi NTT, perempuan tidak diperkenankan makan bersama laki-laki dan harus menunggu giliran makan hingga kaum pria selesai makan. Begitu pula dalam hal bekerja. Anggapan perempuan lebih mampu mencari pekerjaan di luar kampung mendorong orangtua dan suami mendukung perempuan mencari pekerjaan di kota bahkan di luar negeri. Perempuan dianggap mempunyai keterampilan mengerjakan pekerjaanpekerjaan rumah tangga karena hanya pekerjaan itu yang sesuai dengan tingkat pendidikan mereka. Terabaikanya kebutuhan pendidikan bagi perempuan meningkatkan jumlah korban perdagangan orang. Ketimpangan gender dalam masyarakat menyebabkan banyak terjadi kekerasan dalam rumah tangga.

Selain faktor ekonomi dan budaya, pernikahan dini juga merupakan faktor penyebab terjadinya perdagangan orang. Dalam pasa 7 Undang-Undang Nomor 1 Tahun 1974 tentang perkawinan, usia perempuan minimal 16 tahun untuk menikah. Di Indonesia pada tahun 2016 terdapat 750.000 perkawinan usia anak. Pernikahan dini seperti ini paling lama bertahan dua tahun.Hal ini menyebabkan pemenuhan ekonomi keluarga semakin sulit. Hal ini sejalan dengan Dian Kartika Sari (Koalisi Perempuan Indonesia, 2019) yang menegaskan bahwa perkawinan usia muda menjadi akar masalah dari perdagangan orang. Kondisi ekonomi yang lemah menempatkan perempuan dalam posisi yang tidak meguntungkan dibandingkan dengan laki-laki.

Rendahnya pendidikan perempuan berdampak pada kurangnya kesempatan mendapatkan pekerjaan.Pekerjaan yang dilakukan hanya sebatas pembantu rumah tangga. Rendahnya pasarang kerja yang diakibatkan oleh rendahnya tingkat eknomi dan tingkat pendidikan mendorong terjadinya urbanisasi ke kota atau ke negara lain sebagai tempat yang dianggap mudah mencari pekerjaan. Perekrutan perempuan di desa-desa sebagai bentuk memberikan lapangan pekerjaan yang legal, berdampak pada peningkatan jumlah perempuan-perempuan muda ke tempat pelacuran. Penderitaan bahkan kematian yang dialami perempuan yang bekerja di luar negeri sebagai pekerja domestic sebagaimana diungkapkan berbagai media akhir-akhir ini merupakan penderitaan yang mereka alami karena mereka perempuan.

\section{Bentuk Fungsi/Model Diskriminan}

Tabel 9.8 Canonical DiscriminatFunction Coefficient

\begin{tabular}{lr}
\hline \multicolumn{2}{c}{ Function } \\
\hline \multicolumn{2}{c}{1} \\
\hline $\mathrm{X} 1$ & 1.204 \\
\hline $\mathrm{X} 3$ & -0.878 \\
\hline (Constant) & 0.639 \\
\hline
\end{tabular}

Fungsi diskriminan yang dihasilkan adalah

Zscore $=1.204$ Ekonomi dan budaya -0.878 Kesempatan kerja dan penghasilan + 0.639 Pernikahan dini. Fungsi tersebut akan digunakan untuk 
melihat kasus yang baru apakah akan tergolong dalam kelompok perdagangan anak atau buruh imigran. Selanjutnya hasil score akan dibandingkan dengan $\mathrm{Cut}$ Off Score (nilai batas).

Dari fungsi Diskriminan terlihat bahwa variabel Ekonomi dan budaya, serta Pernikahan Dini bernilai positif. Hal ini menunjukkan bahwa variabelvariabel tersebut berpengaruh memperbesar skor diskriminan, artinya semakin besar skor persepsi/semakin responden berpersepsi positif(semakin rendah tingkat ekonomi dan pengetahuan budaya responden) maka skor diskriminan dari fungsi akan semakin besar. Begitu pula semakin dini usia responden saat menikah maka skor diskriminan dari fungsi akan semakin besar.

\section{Ketepatan Klasifikasi/pengelompokan oleh Fungsi Diskriminan}

Tabel 9.9 Function at Grup Centroids

\begin{tabular}{lrr}
\hline \multicolumn{1}{c}{ Bentuk_HT } & \multicolumn{2}{c}{ Function } \\
\cline { 2 - 3 } & \multicolumn{1}{c}{1} \\
\hline Perdagangan anak & & 0.714 \\
Buruh imigran internasional & & -0.668 \\
\hline
\end{tabular}

Tabel 9.10 Prior Probabilities for Groups

\begin{tabular}{lcrr}
\hline & & \multicolumn{3}{c}{ Cases Used in Analysis } \\
\cline { 3 - 5 } Bentuk_HT & Prior & Unweighted & Weighted \\
\hline Perdagangan anak & 0.500 & 29 & 29.000 \\
$\begin{array}{l}\text { Buruh imigran } \\
\text { internasional }\end{array}$ & 0.500 & 31 & 31.000 \\
\hline Total & 1.000 & 60 & 60.000 \\
\hline
\end{tabular}

Tabel 9.11 Classification Results

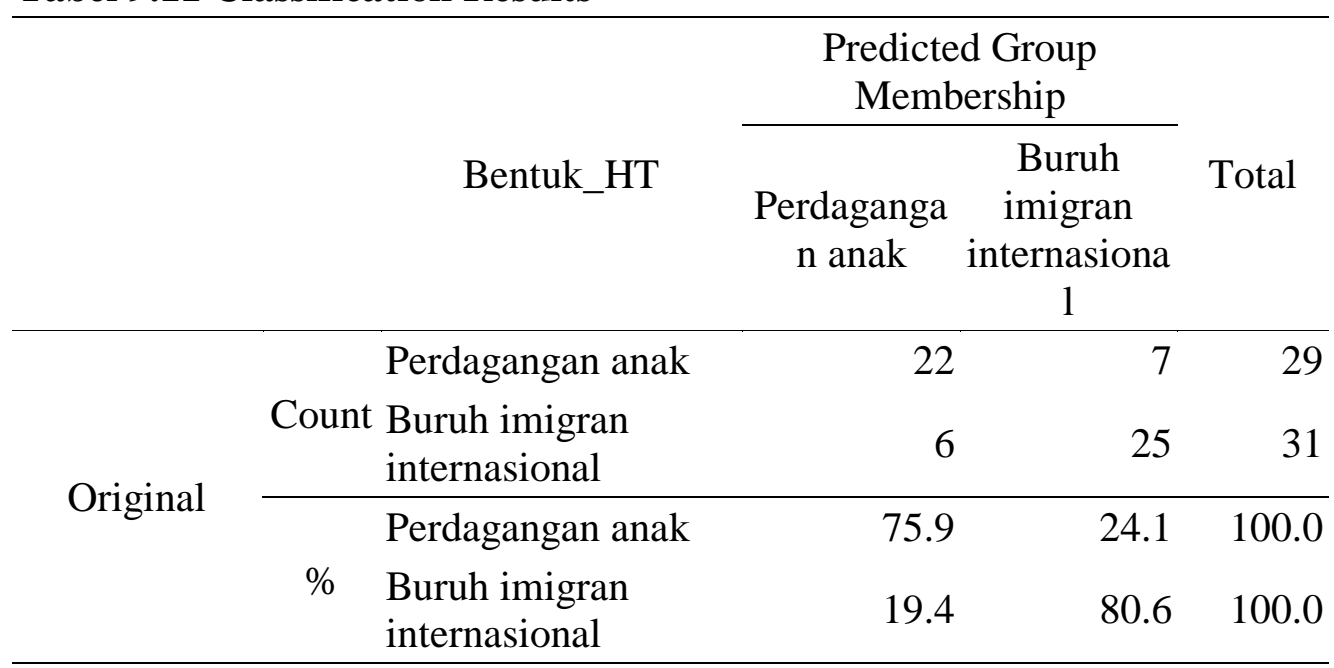

a. $78.3 \%$ of original grouped cases correctly classified.

Dari tabel hasil klasifikasi (Tabel 9.11) menunjukkan bahwa 22 orang merupakan korban Perdagangan Anak dan dari hasil prediksi tetap merupakan korban Perdagangan Anak. Sedangkan tujuh orang yang merupakan korban 
Perdagangan Anak namun dari hasil prediksi tujuh orang tersebut merupakan Buruh Imigran Internasional. Begitupula dengan jumlah Buruh Imigran Internasional yang berjumlah 25 orang, dari hasil prediksi tetap merupakan Buruh Imigran Internasional. Sedangkan enam orang yang awalnya merupakan Buruh Imigran Internasional, dari hasil prediksi merupakan korban Perdagangan Anak.

Model diskriminan pada Tabel 9.11 di atas mempunyai nilai ketepatan klasifikasi kasus sebesar $78.3 \%[((22+25) / 60) * 100 \%]$, dianggap besar karena melebihi $50 \%$ sehingga bisa digunakan untuk mengklasifikasikan kasus Perdagangan Orang. Ada beberapa cara yang dapat digunakan dalam melakukan pengelompokan. Salah satu cara yang dapat digunakan untuk membuat batas nilai (cut off) untuk pengelompokan adalah dengan memanfaatkan Fungsi Diskriminan. Digunakan Tabel 9.9 dan 9.10 untuk menentukan cut off score. Dari Tabel 9.10 diperoleh jumlah responden Perdagangan Anak sebanyak 29 orang dan responden Buruh Imigran Internasional sebanyak 31 orang. Sehingga jika dihubungkan dengan Tabel 9.10, maka diperoleh hasil sebagai berikut :

$(29 \times 0.714)+(31 \times-0,668)=20.706-20.708=-0.002$ atau dianggap sama dengan 0 (nol).

Nilai $Z_{\mathrm{CU}}$ diperoleh dari

$Z_{c U}=\frac{29(-0.668)+31(0.714)}{29+31}=0.692$

Sehingga jika nilai skor kasus $>\mathrm{Z}_{\mathrm{CU}}=0.692$ maka akan termasuk grup Perdangan Anak dan jika Nilai skor $<\mathrm{Z}_{\mathrm{CU}}=0.692$ maka termasuk ke grup Buruh Imigran Internasional

\section{LATIHAN}

1. Dalam rangka mengatur penangkapan ikan salmon, sangat diinginkan bisa mengidentifikasi apakah ikan yang tertangkap berasal dari Alaska atau Kanada. Lima puluh ikan diambil dari setiap tempat, dan pertumbuhan diameternya diukur ketika ikan-ikan itu hidup di air tawar dan ketika hidup di air laut. Tujuannya adalah untuk mengetahui apakah ikan yang tertangkap di kemudian hari berasal dari Alaska atau dari Kanada.

\begin{tabular}{|c|c|c|c|}
\hline Resp & $\begin{array}{c}\text { Asal ikan } \\
\text { Salmon }\end{array}$ & $\begin{array}{c}\text { Air } \\
\text { tawar }\end{array}$ & $\begin{array}{c}\text { Air } \\
\text { laut }\end{array}$ \\
\hline 1 & Alaska & 108 & 368 \\
\hline 2 & Alaska & 131 & 355 \\
\hline 3 & Alaska & 105 & 469 \\
\hline 4 & Alaska & 86 & 506 \\
\hline 5 & Alaska & 99 & 402 \\
\hline 6 & Alaska & 87 & 423 \\
\hline 7 & Alaska & 94 & 440 \\
\hline 8 & Alaska & 117 & 489 \\
\hline 9 & Alaska & 79 & 432 \\
\hline 10 & Alaska & 99 & 403 \\
\hline 11 & Alaska & 114 & 428 \\
\hline 12 & Alaska & 123 & 372 \\
\hline 13 & Alaska & 123 & 372 \\
\hline 14 & Alaska & 109 & 420 \\
\hline
\end{tabular}

\begin{tabular}{|c|c|c|c|}
\hline Resp & $\begin{array}{c}\text { Asal ikan } \\
\text { Salmon }\end{array}$ & $\begin{array}{c}\text { Air } \\
\text { tawar }\end{array}$ & $\begin{array}{c}\text { Air } \\
\text { laut }\end{array}$ \\
\hline 1 & Canada & 148 & 371 \\
\hline 2 & Canada & 179 & 407 \\
\hline 3 & Canada & 152 & 381 \\
\hline 4 & Canada & 166 & 377 \\
\hline 5 & Canada & 124 & 389 \\
\hline 6 & Canada & 156 & 419 \\
\hline 7 & Canada & 131 & 345 \\
\hline 8 & Canada & 140 & 362 \\
\hline 9 & Canada & 144 & 345 \\
\hline 10 & Canada & 149 & 393 \\
\hline 11 & Canada & 108 & 330 \\
\hline 12 & Canada & 135 & 355 \\
\hline 13 & Canada & 170 & 386 \\
\hline 14 & Canada & 152 & 301 \\
\hline
\end{tabular}




\begin{tabular}{|c|c|c|c|c|c|c|c|}
\hline 15 & Alaska & 112 & 394 & 15 & Canada & 153 & 397 \\
\hline 16 & Alaska & 104 & 407 & 16 & Canada & 152 & 301 \\
\hline 17 & Alaska & 111 & 422 & 17 & Canada & 136 & 438 \\
\hline 18 & Alaska & 126 & 423 & 18 & Canada & 122 & 306 \\
\hline 19 & Alaska & 105 & 434 & 19 & Canada & 148 & 383 \\
\hline 20 & Alaska & 119 & 474 & 20 & Canada & 90 & 385 \\
\hline 21 & Alaska & 114 & 396 & 21 & Canada & 145 & 337 \\
\hline 22 & Alaska & 100 & 470 & 22 & Canada & 123 & 364 \\
\hline 23 & Alaska & 84 & 399 & 23 & Canada & 145 & 376 \\
\hline 24 & Alaska & 102 & 429 & 24 & Canada & 115 & 354 \\
\hline 25 & Alaska & 101 & 469 & 25 & Canada & 134 & 383 \\
\hline 26 & Alaska & 85 & 444 & 26 & Canada & 117 & 355 \\
\hline 27 & Alaska & 109 & 397 & 27 & Canada & 126 & 345 \\
\hline 28 & Alaska & 106 & 442 & 28 & Canada & 118 & 379 \\
\hline 29 & Alaska & 82 & 431 & 29 & Canada & 120 & 369 \\
\hline 30 & Alaska & 118 & 381 & 30 & Canada & 153 & 403 \\
\hline 31 & Alaska & 105 & 388 & 31 & Canada & 150 & 354 \\
\hline 32 & Alaska & 121 & 403 & 32 & Canada & 154 & 390 \\
\hline 33 & Alaska & 85 & 451 & 33 & Canada & 155 & 349 \\
\hline 34 & Alaska & 83 & 453 & 34 & Canada & 109 & 325 \\
\hline 35 & Alaska & 53 & 427 & 35 & Canada & 117 & 344 \\
\hline 36 & Alaska & 95 & 411 & 36 & Canada & 128 & 400 \\
\hline 37 & Alaska & 76 & 442 & 37 & Canada & 144 & 403 \\
\hline 38 & Alaska & 95 & 426 & 38 & Canada & 163 & 370 \\
\hline 39 & Alaska & 87 & 402 & 39 & Canada & 1145 & 355 \\
\hline 40 & Alaska & 70 & 397 & 40 & Canada & 133 & 375 \\
\hline 41 & Alaska & 84 & 511 & 41 & Canada & 128 & 383 \\
\hline 42 & Alaska & 91 & 469 & 42 & Canada & 123 & 349 \\
\hline 43 & Alaska & 74 & 451 & 43 & Canada & 144 & 373 \\
\hline 44 & Alaska & 101 & 474 & 44 & Canada & 140 & 388 \\
\hline 45 & Alaska & 80 & 398 & 45 & Canada & 150 & 339 \\
\hline 46 & Alaska & 96 & 433 & 46 & Canada & 124 & 341 \\
\hline 47 & Alaska & 92 & 404 & 47 & Canada & 125 & 346 \\
\hline 48 & Alaska & 99 & 481 & 48 & Canada & 153 & 352 \\
\hline 49 & Alaska & 94 & 491 & 49 & Canada & 208 & 339 \\
\hline 50 & Alaska & 87 & 480 & 50 & Canada & 129 & 420 \\
\hline
\end{tabular}

Dengan menggunakan data di atas, diperoleh matriks ragam-peragam

$$
S=\left[\begin{array}{cc}
676.0 & -649.1 \\
-649.1 & 2138.1
\end{array}\right]
$$

Serta vektor rataan untuk masing-masing populasi adalah

Ikan dari Alaska $\bar{X}_{1}=\left[\begin{array}{c}98.38 \\ 429.66\end{array}\right]$
Ikan dari Canada $\bar{X}_{2}=\left[\begin{array}{l}137.46 \\ 366.62\end{array}\right]$ 
Sehingga diperoleh vektor fungsi diskriminan $a=S^{-1}\left(\bar{x}_{1}-\bar{x}_{2}\right)=\left[\begin{array}{c}-0.0521 \\ 0.0137\end{array}\right]$ dan batasan nilai bagi kedua populasi sebesar $\mathrm{c}=-0.5657$.

Dengan demikian, jika kita memiliki suatu pengamatan baru $\mathrm{x}=(x 1, x 2)$ maka kita akan memasukkannya ke populasi 1 (ikan dari Alaska) jika $-0.0521 x 1+0.0137 x 2 \geq-0.5657$

dan jika sebaliknya maka kita masukkan ke populasi ke-2. Sebagai contoh, jika diperoleh sebuah ikan dengan nilai pengamatan $\mathrm{x}=(103,405)$, maka nilai $\mathrm{a}^{\prime} \mathrm{x}=-0.0521(103)+0.0137(405)=10.918$, dan kita masukkan ke dalam populasi 1 .

2. Klasifikasikan pengamatan berikut berdasarkan jarak mahalanobis, jika diketahui untuk pengamatan $\mathrm{x}=(103,405)$ seperti pada Contoh 1 .

\section{Jawab:}

Berdasarkan Contoh 1, Diperoleh jarak $\mathbf{x}$ terhadap vektor rataan populasi ke-1 dan jarak $\mathbf{x}$ terhadap vektor rataan populasi ke-2 yaitu:

$$
\begin{aligned}
& d 1(\mathrm{x})=0.5421 \\
& d 2(\mathrm{x})=1.3322
\end{aligned}
$$

karena $d 1(\mathrm{x})<d 2(\mathrm{x})$ maka $\mathrm{x}$ diklasifikasikan berasal dari populasi 1 (ikan dari Alaska)

3. Kembali pada $\mathbf{x}$ contoh 1 , dihasilkan $\mathrm{P}(1 \mid \mathbf{x})=0.677$ dan $\mathrm{P}(2 \mid \mathrm{x})=0.323$. Jawab:

Dengan menggunakan peluang posterior, klasifikasikan pengamatan tersebut.

Karena $\mathrm{P}(1 \mid \mathrm{x})>\mathrm{P}(2 \mid \mathrm{x})$ maka $\mathbf{x}$ diklasifikasikan berasal dari Alaska.

\section{DAFTAR PUSTAKA}

Arnold, Steven. 1990. Mathematical Statistics. Prentice-Hall, Inc. New Jersey

Atti, A., Dominirsep D. 2017. Analisis Penciri Status Kualitas Rumah Tinggal untuk Model Kelayakan Rumah Tinggal di Kabupaten Kupang. [Laporan Hasil Penelitian].

Atti, A., Shinta P. 2014. Pemodelan Kasus Penyakit Infeksi Saluran Pernafasan Akut (ISPA) untuk Pengendalian Kasus di Provinsi Nusa Tenggara Timur (NTT). [Laporan Hasil Penelitian].

Geradus, Uda., dkk. 2017. Analisis Faktor-Faktor Penyebab Human Trafficking di Provinsi Nusa Tenggara Timur (NTT). [Laporan Hasil Penelitian].

Johnson, R.A., Wichern, D.W. 2002. Applied Multivariate Statistical Analysis, Fifth Edition. Prentice Hall, New Jersey.

Morrison, D. F. 1990. Multivariate Statistical Method. McGraw-Hill Publishing Company, Singapura.

Sartono B, Affendi FM, Sumertajaya IM, Anggraeni Y. 2003. Analisis Peubah Ganda. Bogor: Institut Pertanian Bogor.

Siswadi., dan B. Suharjo. 1998. Analisis Eksplorasi Data Peubah Ganda. Jurusan Matematika, FMIPA IPB, Bogor. 
Supranto, J. 2004. Analisis Multivariat: Arti dan Interpretasi. PT. Rineka Cipta, Jakarta.

Suryana, T. 1997. Pendugaan Produksi Basah Kulit Btang Kina. Skripsi Jurusan Statistika, FMIPA IPB, Bogor.

Wetherill, G.B. 1986. Regression Analysis With Application. Chapmant and Hall. New York. 


\section{Tabel Normal Baku 1}

\section{Lampiran 2. Tabel Normal Baku}

Tabel di bawah ini menyajikan luas daerah di ujung kanan kurva normal $(P(Z \geq z))$

\begin{tabular}{|c|c|c|c|c|c|c|c|c|c|c|}
\hline$z$ & 0,00 & 0,01 & 0,02 & 0,03 & 0,04 & 0,05 & 6 & 0,07 & 0,08 & 0,09 \\
\hline 0,0 & 0,5000 & 0,4960 & 0,4920 & 0,4880 & 0,4840 & 0,4801 & 1 & 21 & 0,4681 & 464 \\
\hline 0,1 & 0,4602 & 0,4562 & 0,4522 & 0,4483 & 0,4443 & 0,4404 & 0,4364 & 0,4325 & 0,4286 & 0,4247 \\
\hline 2 & 0,4207 & 0,4168 & 0,4129 & 0,4090 & 0,4052 & 0,4013 & 0,3974 & 0,3936 & 0,3897 & 0,3858 \\
\hline 0,3 & 0,3821 & 0,3783 & 3745 & 0,3707 & 3669 & 0,3632 & 0,3594 & 0,3557 & 0,3520 & 0,3483 \\
\hline 0,4 & 0,3446 & 0,3409 & 0,3372 & 0,3336 & 0,3300 & 0,3264 & 0,3228 & 2 & & 812 \\
\hline, 5 & 0,3085 & 0,3050 & 0,3015 & 0,2981 & 0,2946 & 0,2912 & 0,2877 & 0,2843 & 0,2810 & 0,2778 \\
\hline 6 & 0,2743 & 0,2709 & 0,2676 & 0,2643 & 0,2611 & 0,2578 & 0,2546 & 0,2514 & 0,2483 & $0,245 t$ \\
\hline 0,7 & 0,2420 & 0,2389 & 0,2358 & 0,2 & 6 & 66 & 0,2236 & 0,2206 & 0,2177 & 0,2143 \\
\hline 0,8 & 0,2119 & 0,2090 & 0,2061 & 0,2033 & 0,2005 & 0,1977 & 0,1949 & 0,1922 & 0,1894 & 0,1867 \\
\hline 0,9 & 0,1841 & 0,1814 & 88 & 0,1762 & 736 & 0,1711 & 0,1685 & 660 & 0,1635 & 0,1611 \\
\hline 1,0 & 0,1587 & 0,1562 & 39 & 0,1515 & 0,1492 & 0,1469 & 0,1446 & 0,1423 & 0,1401 & 0,1379 \\
\hline 1 & 0,1357 & 0,1335 & 0,1314 & 0,1292 & 0,1271 & 0,1251 & 0,1230 & 0,1210 & 0,1190 & 0,1170 \\
\hline 1,2 & 0,1151 & 0,1131 & 12 & 93 & 75 & 56 & & & 003 & 0,0986 \\
\hline 1,3 & 0,0968 & 0,0951 & 0,0934 & 0,0918 & 0,0901 & 0,0885 & 0,0869 & 0,0853 & 38 & 0,0823 \\
\hline 1,4 & 0,0808 & 0,0793 & 78 & 0,0764 & 0,0749 & 0,0735 & 0,0721 & 0,0708 & 0,0694 & 0,0687 \\
\hline, 5 & 0,0 & 0, & & & & & 0,0594 & 0,0582 & 0,0571 & 0,0659 \\
\hline, 6 & 0,0548 & 0,0537 & 0,0526 & 0,0516 & 0,0505 & 0,0495 & & & & 0,0456 \\
\hline 1,7 & 0,0446 & 0,0436 & 0,0427 & 0,0418 & 0,0409 & 0,0401 & 0,0392 & 0,0384 & & 0,0367 \\
\hline 1,8 & 0,0359 & 0,0351 & 44 & 0,0336 & 0,0329 & 0,0322 & 0,0314 & 0,0307 & 0,0301 & 0,0294 \\
\hline 1,9 & 0,0287 & 0,0281 & 0,0274 & 0,0268 & & 56 & 50 & 0,0244 & 0,0239 & 0,0233 \\
\hline 0 & 0,0228 & 0,0222 & 0,0217 & 0,0212 & 0,0207 & 0,0202 & 0,0197 & 0,0 & 38 & 0,0183 \\
\hline 2.1 & 0,0179 & 0,0174 & 0,0170 & 0,0166 & 0,0162 & 0,0158 & 0,0154 & 0,0150 & 0,0146 & 0.0143 \\
\hline 2.2 & 0,0139 & 0,0136 & 0, & 29 & 0,0125 & 0,0122 & 0,0119 & 0,0116 & 0,0113 & 0,0110 \\
\hline 3 & 0,0107 & 0,0104 & 0,0102 & 0,0099 & 0,0096 & 0,0094 & 0,0091 & 889 & 0,0087 & 0,0084 \\
\hline 2,4 & 0,0082 & 0,0080 & 0,0078 & 0,0075 & 0,0073 & 0,0071 & 0,0069 & 0,0068 & 0,0066 & 0,0064 \\
\hline 2,5 & 0,0062 & $0 ; 0060$ & 0,0059 & 0,0057 & 0,0055 & 0,0054 & 0,0052 & 0,0051 & 0,0049 & $0,00<8$ \\
\hline 2,6 & 0,0047 & 0,0045 & 0,0044 & 0,0043 & 0,0041 & 0,0040 & 0,0039 & 0,0038 & 0,0037 & 0,0036 \\
\hline 2,7 & 0,0035 & 0,0034 & 0,0033 & 0,0032 & 0,0031 & 0,0030 & 0,0029 & 0,0028 & 0,0027 & 0,0026 \\
\hline 2,8 & 0,0026 & 0,0025 & 0,0024 & 0,0023 & 0,0023 & 0,0022 & 0,0021 & 0,0021 & 0,0020 & 0,0019 \\
\hline 2,9 & 0,0019 & 0,0018 & 0,0018 & 0,0017 & 0,0016 & 0,0016 & 0,0015 & 0,0015 & 0,0014 & 0,0014 \\
\hline 3,0 & 0,0013 & 0,0013 & 0,0013 & 0,0012 & 0,0012 & 0,0011 & 0,0011 & 0,0011 & 0,0010 & 0,0010 \\
\hline 3,1 & 0,0010 & 0,0009 & 0,0009 & 0,0009 & 0,0008 & 0,0008 & 0,0008 & 0,0008 & 0,0007 & 0,0007 \\
\hline 3,2 & 0,0007 & 0,0007 & 0,0006 & 0,0006 & 0,0006 & 0,0006 & 0,0006 & 0,0005 & 0,0005 & 0,0005 \\
\hline
\end{tabular}




\section{Tabel Normal Baku 2}

Masing-masing sel berisi nilai sebaran peubah acak normal baku $(0, z)$ :

$$
\begin{aligned}
\int_{0}^{Z} N(0,1) d x ; & \text { Misalnya } 0.3289 \\
& =\int_{0}^{0.95} N(0,1) d x=\mathrm{P}(0.0<\mathrm{Z}<0.95
\end{aligned}
$$

\begin{tabular}{|c|c|c|c|c|c|c|c|c|c|}
\hline .00 & .01 & .02 & .03 & .04 & .05 & .06 & .07 & .08 & .09 \\
\hline .0000 & .0040 & .0080 & .0120 & .0160 & .0199 & .0239 & .0279 & 9 & .0359 \\
\hline .0398 & .0438 & .0478 & .0517 & .0557 & .0596 & .0636 & .0675 & & .0753 \\
\hline .0793 & .0832 & .0871 & .0910 & .0948 & .0987 & .1026 & .1064 & .1103 & .1141 \\
\hline .1179 & .1217 & .1255 & .1293 & .1331 & .1368 & .1406 & .1443 & & .1517 \\
\hline .1554 & .1591 & .1628 & .1664 & .1700 & .1736 & .1772 & .1808 & .1844 & .1879 \\
\hline .1915 & 50 & .1985 & .2019 & .2054 & .2088 & 3 & & .2190 & .2224 \\
\hline .2257 & .2291 & .2324 & .2357 & .2389 & .2422 & .2454 & .2486 & .2517 & .2549 \\
\hline .2580 & .2611 & .2642 & .2673 & .2704 & .2734 & .2764 & .2794 & .2823 & .2852 \\
\hline .2881 & .2910 & .2939 & .2967 & .2995 & .3023 & .3051 & .3078 & .3106 & .3133 \\
\hline .3159 & .3186 & .3212 & .3238 & .3264 & .3289 & .3315 & .3340 & .3365 & 3389 \\
\hline .3413 & .34 & .3461 & .3485 & .3508 & .3531 & .3554 & .3577 & .3599 & .3 \\
\hline .3643 & .3665 & .3686 & .3708 & .3729 & .3749 & .3770 & .3790 & .3810 & .3830 \\
\hline .3849 & .3869 & .3888 & .3907 & .3925 & .3944 & .3962 & .3980 & .3997 & .4015 \\
\hline .4032 & .4049 & .4066 & .4082 & .4099 & .4115 & .4131 & .4147 & .4162 & .4177 \\
\hline .4192 & .4207 & .4222 & .4236 & .4251 & .4265 & .4279 & .4292 & .4306 & .4319 \\
\hline .4332 & .4345 & .4357 & .4370 & .4 & .4394 & .4406 & .4418 & .4429 & .4441 \\
\hline .4452 & .4463 & .4474 & .4484 & .4495 & .4505 & .4515 & .4525 & .4535 & .4545 \\
\hline .4554 & .4564 & .4573 & .4582 & .4591 & .4599 & .4608 & .4616 & .4625 & .4633 \\
\hline .4641 & .4649 & .4656 & .4664 & .4671 & .4678 & .4686 & .4693 & .4699 & .4706 \\
\hline .4713 & .4719 & .4726 & .4732 & .4738 & .4744 & .4750 & .4756 & .4761 & .4767 \\
\hline .4772 & .4778 & .4783 & .4788 & .4793 & .4798 & .4803 & .4808 & .4812 & .4817 \\
\hline .4821 & .4826 & .4830 & .4834 & .4838 & .4842 & .4846 & .4850 & .4854 & .4857 \\
\hline .4861 & .4864 & .4868 & .4871 & .4875 & .4878 & .4881 & .4884 & .4887 & .4890 \\
\hline .4893 & .4896 & .4898 & .4901 & .4904 & .4906 & .4909 & .4911 & .4913 & .4916 \\
\hline .4918 & .4920 & .4922 & .4925 & .4927 & .4929 & .4931 & .4932 & .4934 & .4936 \\
\hline .4938 & .4940 & .4941 & .4943 & .4945 & .4946 & .4948 & .4949 & .4951 & 52 \\
\hline .4953 & .4955 & .4956 & .4957 & .4959 & .4960 & .4961 & .4962 & .4963 & .4964 \\
\hline .4965 & .4966 & .4967 & .4968 & .4969 & .4970 & .4971 & .4972 & .4973 & .4974 \\
\hline .4974 & .4975 & .4976 & .4977 & .4977 & .4978 & .4979 & .4979 & .4980 & .4981 \\
\hline .4981 & .4982 & .4982 & .4983 & .4984 & .4984 & .4985 & .4985 & .4986 & .4986 \\
\hline .4987 & .4987 & .4987 & .4988 & .4988 & .4989 & .4989 & .4989 & .4990 & .4990 \\
\hline .4990 & .4991 & .4991 & .4991 & .4992 & .4992 & .4992 & .4992 & .4993 & .4993 \\
\hline .4993 & .4993 & .4994 & .4994 & .4994 & .4994 & .4994 & .4995 & .4995 & .4995 \\
\hline .4995 & .4995 & .4995 & .4996 & .4996 & .4996 & .4996 & .4996 & .4996 & .4997 \\
\hline .4997 & 4997 & .4997 & .4997 & .4997 & .4997 & .4997 & .4997 & .4997 & .4998 \\
\hline
\end{tabular}

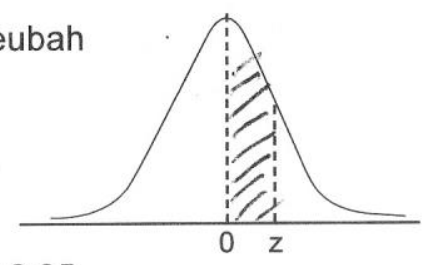




\subsection{SOAL LATIHAN}

1. Lampu jalan yang dipasang di kota Pontianak mempunyai ketahanan hidup rata-rata 500 hari dengan standar deviasi 50 hari. Jika ketahanan hidup lampu jalan tersebut dapat diasumsikan berdistribusi normal, tentukan peluang bahwa lampu jalan tersebut dapat bertahan hidup selama
a. Lebih dari dua tahun
b. Antara 400 sampai 600 hari
c. Kurang dari 450 hari

2. Tentukan luas daerah di bawah kurva normal baku bagi nilai-nilai z berikut :
a. $Z>1,96$
b. Z>1,64
c. $\mathrm{Z}>2,33$

3. Tentukan luas daerah di bawah kurva normal baku bagi nilai-nilai z berikut :
a. $-1,96<\mathrm{Z}<1,96$
b. $-2,33<Z<2,33$

4. Sebuah bank menerbitkan kartu kredit. Diperkirakan mean dari nilai kartu kredit tersebut $\$ 845$ dengan standar deviasi $\$ 275$. Jika nilai kartu kredit tersebut berdistribusi normal.
a. Berapakah probabilitas bahwa kartu kredit yang diambil secara acak akan bernilai antara $\$ 1.000$ sampai $\$ 1.400$ ?
b. Berapa persentase dari kartu kredit yang bernilai lebih dari $\$ 750$

\section{DAFTAR PUSTAKA}

Hakim, A. 2002. Statistik Induktif (untuk Ekonomi dan Bisnis). Ekonisia. Yogyakarta.

Kusnandar, D. 2004. Metode Statistika dan Aplikasinya dengan Minitab dan Excel. Madyan Press. Yogyakarta.

Saefuddin, A., dkk. 2009. Statistika Dasar. Grasindo. Jakarta. 
ISBN 978-602-6478-76-4

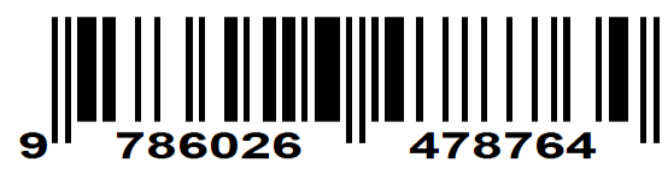

